Cover:

Background, Rush Springs aquifer outcrop near Binger, Oklahoma, 2010. Photograph taken by Shana Mashburn.

Top right, Real-time well near Hinton, Oklahoma, 2010. Photograph taken by Shana Mashburn.

Top left, Rush Springs aquifer outcrop near Binger, Oklahoma, 2010. Photograph taken by Shana

Mashburn.

Bottom left, Spring near Colony, Oklahoma, 2011. Photograph taken by S. Jerrod Smith.

Bottom right, Rush Springs aquifer outcrop near Binger, Oklahoma, 2010. Photograph taken by Shana Mashburn. 


\section{Evaluation of Groundwater and Surface- Water Interactions in the Caddo Nation Tribal Jurisdictional Area, Caddo County, Oklahoma, 2010-13}

By Shana L. Mashburn and S. Jerrod Smith

Prepared in cooperation with the Caddo Nation, the Bureau of Indian Affairs, and the Bureau of Reclamation

Scientific Investigations Report 2014-5082 


\section{U.S. Department of the Interior \\ SALLY JEWELL, Secretary}

\section{U.S. Geological Survey \\ Suzette M. Kimball, Acting Director}

\section{U.S. Geological Survey, Reston, Virginia: 2014}

For more information on the USGS — the Federal source for science about the Earth, its natural and living resources, natural hazards, and the environment, visit http://www.usgs.gov or call 1-888-ASK-USGS.

For an overview of USGS information products, including maps, imagery, and publications, visit http://www.usgs.gov/pubprod

To order this and other USGS information products, visit http://store.usgs.gov

Any use of trade, firm, or product names is for descriptive purposes only and does not imply endorsement by the U.S. Government.

Although this information product, for the most part, is in the public domain, it also may contain copyrighted materials as noted in the text. Permission to reproduce copyrighted items must be secured from the copyright owner.

Suggested citation:

Mashburn, S.L., and Smith, S.J., 2014, Evaluation of groundwater and surface-water interactions in the Caddo Nation Tribal Jurisdictional Area, Caddo County, Oklahoma, 2010-13: U.S. Geological Survey Scientific Investigations Report 2014-5082, 54 p., http://dx.doi.org/10.3133/sir20145082.

ISSN 2328-031X (print)

ISSN 2328-0328 (online)

ISBN 978-1-4113-3791-6 


\section{Acknowledgments}

The authors are indebted to Polly Edwards, Environmental Director of the Caddo Nation, who had the vision for this study and realized the benefits that would be provided to the Caddo Nation for long-term water planning. The U.S. Geological Survey Oklahoma Water Science Center and Caddo Nation appreciate the funds provided for this study by the Bureau of Indian Affairs and the Bureau of Reclamation Native American Affairs Technical Assistance Program. The authors also thank the private landowners who provided access to their lands for data collection. Progress on the study could not have been made without the landowners' cooperation. 



\section{Contents}

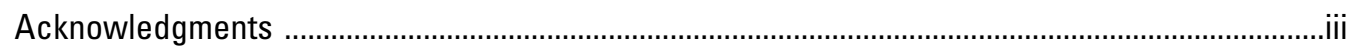

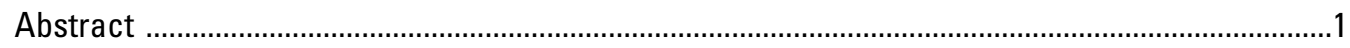

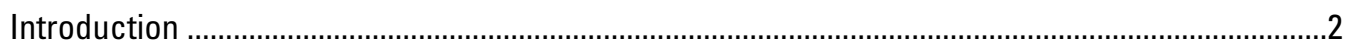

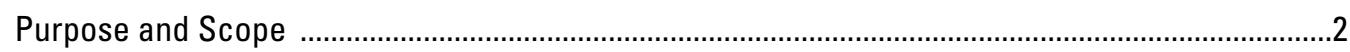

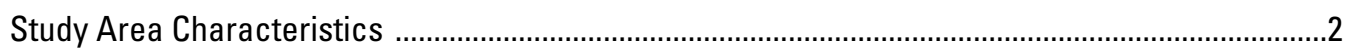

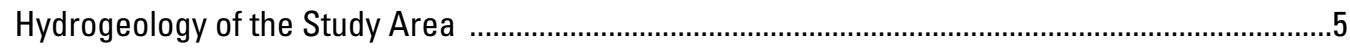

Base Flow from the Rush Springs Aquifer ..............................................................................

Interaction between Groundwater and Surface Water of the Rush Springs Aquifer .....................23

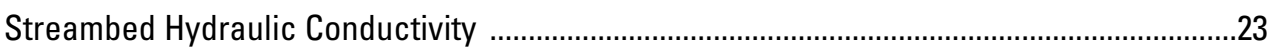

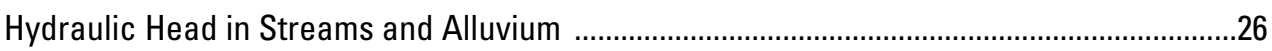

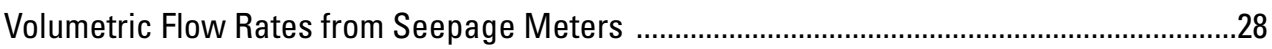

Interaction between Groundwater and Surface Water at Cobb Creek near the Eakly, Oklahoma, Streamflow-Gaging Station .......................................................................30

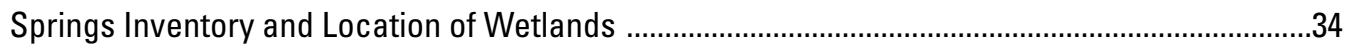

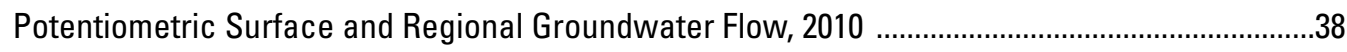

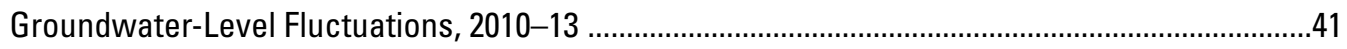

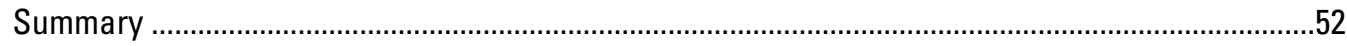

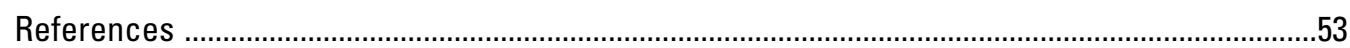

\section{Figures}

1. Map showing study area, surficial geologic units, and locations of water-level monitoring wells and Mesonet stations, southwestern Oklahoma

2. Graph showing precipitation for Oklahoma Climatological Survey Climate Division 7

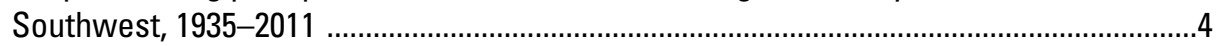

3. Pie diagram showing water use from the Rush Springs aquifer, 2005 ...........................5

4. Graph showing groundwater withdrawals in Caddo County, Oklahoma, 1985-2005

5. Graph showing example of base flow determined by using the PART method and streamflow at streamflow-gaging station 07325850 (Lake Creek near Eakly, Oklahoma), March-July 2007

6. Map showing location of U.S. Geological Survey streamflow-gaging stations in the vicinity of the Rush Springs aquifer

7. Graph showing daily streamflow and base flow derived by using the PART method for streamflow-gaging station 07325840 (Lake Creek near Sickles, Oklahoma), 2006-12

8. Graphs showing $(A)$ average annual streamflow and base flow, $(B)$ base-flow index, $(C)$ average annual streamflow and base-flow volume, and $(D)$ monthly mean streamflow, base flow, and runoff at streamflow-gaging station 07325840 (Lake Creek near Sickles, Oklahoma), 2006-12

9. Graph showing daily streamflow and base flow derived by using the PART method for streamflow-gaging station 07325850 (Lake Creek near Eakly, 
10. Graph showing $(A)$ average annual streamflow and base flow, $(B)$ base-flow index, $(C)$ average annual streamflow and base-flow volume, and $(D)$ monthly mean streamflow, base flow, and runoff at streamflow-gaging station 07325850 (Lake Creek near Eakly, Oklahoma), 1970-77

11. Graph showing daily streamflow and base flow derived by using the PART method for streamflow-gaging station 07325850 (Lake Creek near Eakly, Oklahoma), 2005-12

12. Graph showing $(A)$ average annual streamflow and base flow, $(B)$ base-flow index, $(C)$ average annual streamflow and base-flow volume, and $(D)$ monthly mean streamflow, base flow, and runoff at streamflow-gaging station 07325850 (Lake Creek near Eakly, Oklahoma), 2005-12

13. Graph showing daily streamflow and base flow derived by using the PART method for streamflow-gaging station 07325860 (Willow Creek near Albert, Oklahoma), 1971-77

14. Graph showing $(A)$ average annual streamflow and base flow, $(B)$ base-flow index, $(C)$ average annual streamflow and base-flow volume, and $(D)$ monthly mean streamflow, base flow, and runoff at streamflow-gaging station 07325860 (Willow Creek near Albert, Oklahoma), 1971-77

15. Graph showing daily streamflow and base flow derived by using the PART method for streamflow-gaging station 07325860 (Willow Creek near Albert, Oklahoma), 2005-12

16. Graph showing $(A)$ average annual streamflow and base flow, $(B)$ base-flow index, $(C)$ average annual streamflow and base-flow volume, and $(D)$ monthly mean streamflow, base flow, and runoff at streamflow-gaging station 07325860 (Willow Creek near Albert, 0klahoma), 2005-12

17. Graph showing daily streamflow and base flow derived by using the PART method for streamflow-gaging station 07326000 (Cobb Creek near Fort Cobb, Oklahoma), 1940-58

18. Graph showing $(A)$ average annual streamflow and base flow, $(B)$ base-flow index, $(C)$ average annual streamflow and base-flow volume, and $(D)$ monthly mean streamflow, base flow, and runoff at streamflow-gaging station 07326000 (Cobb Creek near Fort Cobb, Oklahoma), 1940-58

19. Graph showing daily streamflow and base flow derived by using the PART method for streamflow-gaging station 073274406 (Little Washita River above SCS [Soil Conservation Service] Pond No. 26 near Cyril, Oklahoma), 1996-2012

20. Graph showing $(A)$ average annual streamflow and base flow, $(B)$ base-flow index, $(C)$ average annual streamflow and base-flow volume, and $(D)$ monthly mean streamflow, base flow, and runoff at streamflow-gaging station 073274406 (Little Washita River above SCS [Soil Conservation Service] Pond No. 26 near Cyril, Oklahoma), 1996-2012

21. Map showing sites where slug tests and potentiomanometer readings were performed in July 2012 to determine hydraulic conductivity of streambed sediments in Caddo and Washita Counties, Oklahoma

22. Photograph showing temporary small-diameter well with pneumatic slug-test equipment installed

23. Photographs showing potentiomanometer and temporary small-diameter well, with the manometer mounted on a wooden board

24. Diagram showing groundwater and surface-water data-collection stations at Cobb Creek near Eakly, Oklahoma, on Oklahoma State Highway 152 
25. Schematic diagram showing cross sections of a piezometer transect in the Cobb Creek alluvium showing altitudes of Cobb Creek and the alluvial aquifer water table during $(A)$ flooding-stream conditions on November 8, 2011, 2:30 a.m.; $(B)$ normal, gaining-stream conditions on March 1, 2012, 8:30 a.m.; and $(C)$ losing-stream conditions on July 29, 2012, 8:30 a.m.

26. Graph showing water-table altitudes measured at U.S. Geological Survey streamflow-gaging station 07325800 (Cobb Creek near Eakly, Oklahoma) and in three piezometers in the Cobb Creek alluvium showing altitudes of Cobb Creek and the alluvial groundwater table and precipitation measured at Weatherford, Okla., Mesonet station, September 2011-August 2012

27. Map showing locations of springs and stream observations in and near the Caddo Nation Tribal Jurisdictional Area, Oklahoma, September 2011

28. Map showing locations of wetlands and frequently flooded soils in and around the Caddo Nation Tribal Jurisdictional Area, Oklahoma . .37

29. Map showing the potentiometric surface of the Rush Springs aquifer in Caddo County, Oklahoma, July 2010.

30. Map showing the potentiometric surface of the Rush Springs aquifer in Caddo County, Oklahoma, January 2011

31. Graph showing groundwater levels measured in U.S. Geological Survey well 350748098231101 near Gracemont, Oklahoma, October 2010-June 2013

32. Graph showing groundwater levels measured in U.S. Geological Survey well 351308098341601 near Alfalfa, Oklahoma, October 2010-June 2013

33. Graph showing groundwater levels measured in U.S. Geological Survey well 351308098341601 near Alfalfa, Oklahoma, August 1948-June 2013

34. Graph showing groundwater levels measured in U.S. Geological Survey well 351727098290401 Core 2, October 2010-June 2013

35. Graph showing groundwater levels measured in U.S. Geological Survey well 351727098290401 Core 2, December 1989-June 2013

36. Graph showing groundwater levels measured in U.S. Geological Survey well 352423098341701 near Eakly, Oklahoma, October 2010-June 2013

37. Graph showing groundwater levels measured in U.S. Geological Survey well 352423098341701 near Eakly, Oklahoma, April 1965-June 2013

38. Graph showing groundwater levels measured in U.S. Geological Survey well 352802098191601 near Hinton, Oklahoma, October 2010-June 2013

39. Graphs showing monthly precipitation for Hinton and Fort Cobb Mesonet Stations, Oklahoma, October 2010-May 2013

40. Graph showing groundwater levels monitored with a vented pressure transducer and barometric pressure at U.S. Geological Survey well 352702098191601 near Hinton, Oklahoma, showing barometric efficiency typical of the unconfined part of the Rush Springs aquifer 


\section{Tables}

1. List of streamflow-gaging stations located near the Rush Springs aquifer, southwestern Oklahoma, with periods analyzed using the PART method

2. Completion information for temporary wells installed in the area underlain by the Rush Springs aquifer, southwestern Oklahoma, 2012

3. Horizontal hydraulic conductivity determined from slug tests conducted in the streambed sediments of streams overlying the Rush Springs aquifer, southwestern Oklahoma, August 2012

4. Hydraulic head differences and gradients between streams and alluvium determined from potentiomanometer readings, in areas underlain by the Rush Springs aquifer, southwestern Oklahoma, August 2012

5. Seepage locations and flux velocities for sites measured in the area underlain by the Rush Springs aquifer, southwestern Oklahoma, July-August 2012

6. Real-time continuous groundwater-level monitoring wells in the area underlain by the Rush Springs aquifer, southwestern Oklahoma, October 2010-June 2013 


\section{Conversion Factors}

Inch/Pound to SI

\begin{tabular}{|c|c|c|}
\hline Multiply & By & To obtain \\
\hline \multicolumn{3}{|c|}{ Length } \\
\hline inch (in.) & 2.54 & centimeter $(\mathrm{cm})$ \\
\hline inch (in.) & 25.4 & millimeter $(\mathrm{mm})$ \\
\hline foot $(\mathrm{ft})$ & 0.3048 & meter $(\mathrm{m})$ \\
\hline mile (mi) & 1.609 & kilometer (km) \\
\hline \multicolumn{3}{|c|}{ Area } \\
\hline acre & 4,047 & square meter $\left(\mathrm{m}^{2}\right)$ \\
\hline acre & 0.004047 & square kilometer $\left(\mathrm{km}^{2}\right)$ \\
\hline square foot $\left(\mathrm{ft}^{2}\right)$ & 929.0 & square centimeter $\left(\mathrm{cm}^{2}\right)$ \\
\hline square foot $\left(\mathrm{ft}^{2}\right)$ & 0.09290 & square meter $\left(\mathrm{m}^{2}\right)$ \\
\hline square inch $\left(\right.$ in $\left.^{2}\right)$ & 6.452 & square centimeter $\left(\mathrm{cm}^{2}\right)$ \\
\hline $\begin{array}{l}\text { section ( } 640 \text { acres or } 1 \text { square } \\
\text { mile) }\end{array}$ & 259.0 & square hectometer $\left(\mathrm{hm}^{2}\right)$ \\
\hline square mile $\left(\mathrm{mi}^{2}\right)$ & 259.0 & hectare (ha) \\
\hline square mile $\left(\mathrm{mi}^{2}\right)$ & 2.590 & square kilometer $\left(\mathrm{km}^{2}\right)$ \\
\hline \multicolumn{3}{|c|}{ Volume } \\
\hline gallon (gal) & 3.785 & liter $(\mathrm{L})$ \\
\hline gallon (gal) & 0.003785 & cubic meter $\left(\mathrm{m}^{3}\right)$ \\
\hline million gallons (Mgal) & 3,785 & cubic meter $\left(\mathrm{m}^{3}\right)$ \\
\hline acre-foot (acre-ft) & 1,233 & cubic meter $\left(\mathrm{m}^{3}\right)$ \\
\hline \multicolumn{3}{|c|}{ Flow rate } \\
\hline foot per day $(\mathrm{ft} / \mathrm{d})$ & 0.3048 & meter per day $(\mathrm{m} / \mathrm{d})$ \\
\hline foot per year (ft/yr) & 0.3048 & meter per year (m/yr) \\
\hline cubic foot per second $\left(\mathrm{ft}^{3} / \mathrm{s}\right)$ & 0.02832 & cubic meter per second $\left(\mathrm{m}^{3} / \mathrm{s}\right)$ \\
\hline cubic foot per day $\left(\mathrm{ft}^{3} / \mathrm{d}\right)$ & 0.02832 & cubic meter per day $\left(\mathrm{m}^{3} / \mathrm{d}\right)$ \\
\hline gallon per minute (gal/min) & 0.06309 & liter per second $(\mathrm{L} / \mathrm{s})$ \\
\hline million gallons per day (Mgal/d) & 0.04381 & cubic meter per second $\left(\mathrm{m}^{3} / \mathrm{s}\right)$ \\
\hline inch per year (in/yr) & 25.4 & millimeter per year $(\mathrm{mm} / \mathrm{yr})$ \\
\hline \multicolumn{3}{|c|}{ Hydraulic conductivity } \\
\hline foot per day (ft/d) & 0.3048 & meter per day $(\mathrm{m} / \mathrm{d})$ \\
\hline
\end{tabular}

Vertical coordinate information is referenced to the North American Vertical Datum of 1988 (NAVD 88) and the National Geodetic Vertical Datum of 1929 (NGVD 29). The NAVD 88 replaced the NGVD 29, previously known as the Sea Level Datum of 1929.

Horizontal coordinate information is referenced to the North American Datum of 1983 (NAD 83).

Altitude, as used in this report, refers to distance above the vertical datum.

Temperature in degrees Fahrenheit $\left({ }^{\circ} \mathrm{F}\right)$ may be converted to degrees Celsius $\left({ }^{\circ} \mathrm{C}\right)$ as follows:

${ }^{\circ} \mathrm{C}=\left({ }^{\circ} \mathrm{F}-32\right) / 1.8$ 



\title{
Evaluation of Groundwater and Surface-Water Interactions in the Caddo Nation Tribal Jurisdictional Area, Caddo County, Oklahoma, 2010-13
}

\author{
By Shana L. Mashburn and S. Jerrod Smith
}

\section{Abstract}

Streamflows, springs, and wetlands are important natural and cultural resources to the Caddo Nation. Consequently, the Caddo Nation is concerned about the vulnerability of the Rush Springs aquifer to overdrafting and whether the aquifer will continue to be a viable source of water to tribal members and other local residents in the future. Interest in the longterm viability of local water resources has resulted in ongoing development of a comprehensive water plan by the Caddo Nation. As part of a multiyear project with the Caddo Nation to provide information and tools to better manage and protect water resources, the U.S. Geological Survey studied the hydraulic connection between the Rush Springs aquifer and springs and streams overlying the aquifer.

The Caddo Nation Tribal Jurisdictional Area is located in southwestern Oklahoma, primarily in Caddo County. Underlying the Caddo Nation Tribal Jurisdictional Area is the Permian-age Rush Springs aquifer. Water from the Rush Springs aquifer is used for irrigation, public, livestock and aquaculture, and other supply purposes. Groundwater from the Rush Springs aquifer also is withdrawn by domestic (selfsupplied) wells, although domestic use was not included in the water-use summary in this report. Perennial streamflow in many streams and creeks overlying the Rush Springs aquifer, such as Cobb Creek, Lake Creek, and Willow Creek, originates from springs and seeps discharging from the aquifer.

This report provides information on the evaluation of groundwater and surface-water resources in the Caddo Nation Jurisdictional Area, and in particular, information that describes the hydraulic connection between the Rush Springs aquifer and springs and streams overlying the aquifer. This report also includes data and analyses of base flow, evidence for groundwater and surface-water interactions, locations of springs and wetland areas, groundwater flows interpreted from potentiometric-surface maps, and hydrographs of water levels monitored in the Caddo Nation Tribal Jurisdictional Area from 2010 to 2013.

Flow in streams overlying the Rush Springs aquifer, on average, were composed of 50 percent base flow in most years. Monthly mean base flow appeared to maintain streamflows throughout each year, but periods of zero flow were documented in daily hydrographs at each measured site, typically in the summer months.

A pneumatic slug-test technique was used at 15 sites to determine the horizontal hydraulic conductivity of streambed sediments in streams overlying the Rush Springs aquifer. Converting horizontal hydraulic conductivities $(\mathrm{Kh})$ from the slug-test analyses to vertical hydraulic conductivities $(\mathrm{Kv})$ by using a ratio of $\mathrm{Kv} / \mathrm{Kh}=0.1$ resulted in estimates of vertical streambed hydraulic conductivity ranging from 0.1 to 8.6 feet per day. Data obtained from a hydraulic potentiomanometer in streambed sediments and streams in August 2012 indicate that water flow was from the streambed sediments to the stream (gaining) at 6 of 15 sites, and that water flow was from the stream to the streambed sediments (losing) at 9 of 15 sites.

The groundwater and surface-water interaction data collected at the Cobb Creek near Eakly, Okla., streamflow gaging station (07325800), indicate that the bedrock groundwater, alluvial groundwater, and surface-water resources are closely connected. Because of this hydrologic connection, large perennial streams in the study area may change from gaining to losing streams in the summer. The timing and severity of this change from a gaining to a losing condition probably is affected by the local or regional withdrawal of groundwater for irrigation in the summer growing season. Wells placed closer to streams have a greater and more immediate effect on alluvial groundwater levels and stream stages than wells placed farther from streams. Largecapacity irrigation wells, even those completed hundreds of feet below land surface in the bedrock aquifer, can induce surface-water flow from nearby streams by lowering alluvial groundwater levels below the stream altitude.

Twenty-five new springs visible from public roads and paths were documented during a survey of springs in 2011. Most of the springs are in upland draws on the flanks of topographic ridges. Wetlands primarily were identified by using a combination of data sources including the National Wetlands Inventory, Soil Survey Geographic database frequently flooded soils maps, and aerial photographs.

Regional flow directions were determined by analysis of water levels measured in 29 wells completed in the Rush 
Springs aquifer in Caddo County and the Caddo Nation Tribal Jurisdictional Area. Water levels were monitored every 30 minutes in five wells by using a vented pressure transducer and a data-collection platform with real-time transmitting equipment in each well. Those five wells ranged in depth from 210 to 350 feet. Water levels in these five wells indicate that there was a decrease in water storage in the Rush Springs aquifer from October 2010 to June 2013.

\section{Introduction}

The Caddo Nation Tribal Jurisdictional Area is located in southwestern Oklahoma, primarily in Caddo County, Okla. (fig. 1). Underlying the Caddo Nation Tribal Jurisdictional Area is the Permian-age Rush Springs aquifer. Water from the Rush Springs aquifer is used for irrigation, public, livestock and aquaculture, and domestic supply purposes (Tortorelli, 2009). A Permian-age sandstone bedrock aquifer, the Rush Springs aquifer is unconfined in most locations where groundwater is pumped, has a maximum thickness of approximately $300 \mathrm{feet}(\mathrm{ft})$, and can produce well yields in excess of 1,000 gallons per minute (gal/min) (Becker and Runkle, 1998). Perennial streamflow in many streams and creeks overlying the Rush Springs aquifer, such as Cobb Creek, Lake Creek, and Willow Creek, originates from springs and seeps discharging from the aquifer. Three surface-water reservoirs, constructed in and near the Rush Springs aquifer, that depend on perennial streamflows are: (1) Fort Cobb Reservoir and (2) Foss Reservoir (fig. 1), both managed by Bureau of Reclamation; and (3) Lake Chickasha, managed by the City of Chickasha (fig. 1).

The Caddo Nation is concerned about the vulnerability of the Rush Springs aquifer to overdrafting and whether the aquifer will continue to be a viable source of water to tribal members and other local residents in the future. Wells have been completed in the Caddo Nation Tribal Jurisdictional Area that transfer groundwater outside of that jurisdictional area (Christopher Neel, Oklahoma Water Resources Board, written commun., 2012). These groundwater transfers have increased the awareness of the Caddo Nation to the potential for overdrafting of groundwater in the Rush Springs aquifer. Streamflows, springs, and wetlands are important natural and cultural resources to the Caddo Nation. Interest in the long-term viability of water resources in this area has led to the ongoing development of a comprehensive water plan by the Caddo Nation. A comprehensive water plan will provide guidelines for sustainable development and preservation of the water resources in the Caddo Nation Tribal Jurisdictional Area (fig. 1). The U.S. Geological Survey (USGS), in cooperation with the Caddo Nation, initiated a multiyear study in 2008 to provide information and tools that can be used to manage and protect water resources as part of development of a Caddo Nation comprehensive water plan.

\section{Purpose and Scope}

The purpose of this report is to provide information on the evaluation of groundwater and surface-water resources in the Caddo Nation Tribal Jurisdictional Area, and in particular, information that describes the hydraulic connection between the Rush Springs aquifer and springs and streams overlying the aquifer. The study area is the Caddo Nation Tribal Jurisdictional Area (fig. 1). The scope of this report includes data and analyses of base flow in streams, evidence for groundwater and surface-water interactions, locations of springs and wetland areas, groundwater flows interpreted from potentiometric-surface maps, and hydrographs of water levels monitored in the area and near to the Caddo Nation Tribal Jurisdictional Area.

\section{Study Area Characteristics}

The Caddo Nation Tribal Jurisdictional Area (hereafter referred to as "the study area") encompasses primarily Caddo County, Okla. (fig. 1). The topography in the study area is characterized by moderately rolling hills with incised deep drainage channels. The major drainage channels are associated with the Washita River and Cobb and Sugar Creeks. Sugar Creek and its tributaries have deeply cut channels and canyons of dendritic patterns formed by headward erosion (Tanaka and Davis, 1963). The western part of the study area is characterized by cuestas and buttes capped with dolomite or gypsum (Tanaka and Davis, 1963).

Land use in the study area consists mostly of cultivated crops and grasslands. Some evergreen and deciduous forests are located in the upland draws of creeks. Cultivated crops in this area consist of wheat, alfalfa, cotton, and other minor crops (National Agriculture Statistics Service, 2013). Animal production in this area includes beef cattle, hogs, sheep, and poultry (National Agriculture Statistics Service, 2013).

Climate data for the study area were summarized from 1935 through 2011 from the Oklahoma Climate Division 7 Southwest (National Oceanic and Atmospheric Administration, 2012). The average annual air temperature from 1935 through 2011 in the study area was 61.1 degrees Fahrenheit, with the coldest temperatures typically being measured in January and the hottest temperatures typically being measured in July. Average annual precipitation from 1935 through 2011 was 28.3 inches per year (in/yr), with the 5 -year weighted moving average shown on figure 2 . A wetter period is indicated on figure 2 when the 5-year weighted average is greater than the 1935 through 2011 average. A drier period is indicated when the 5-year weighted average is less than the 1935 through 2011 average. A persistent drier period occurred from 1951 through 1959. A persistent wetter period occurred from 1985 through 2001 (fig. 2). 


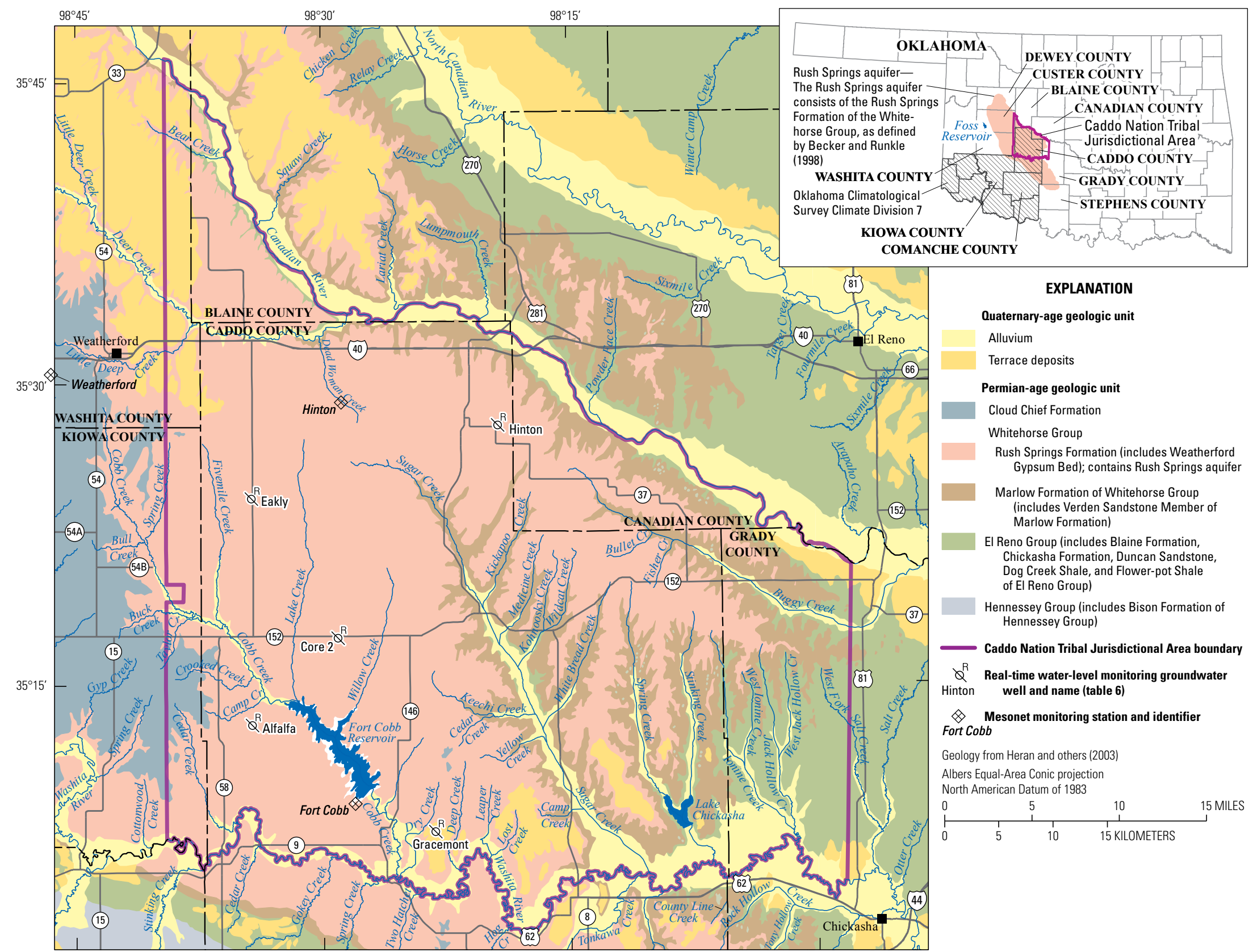

Figure 1. Study area, surficial geologic units, and locations of water-level monitoring wells and Mesonet stations, southwestern Oklahoma. 


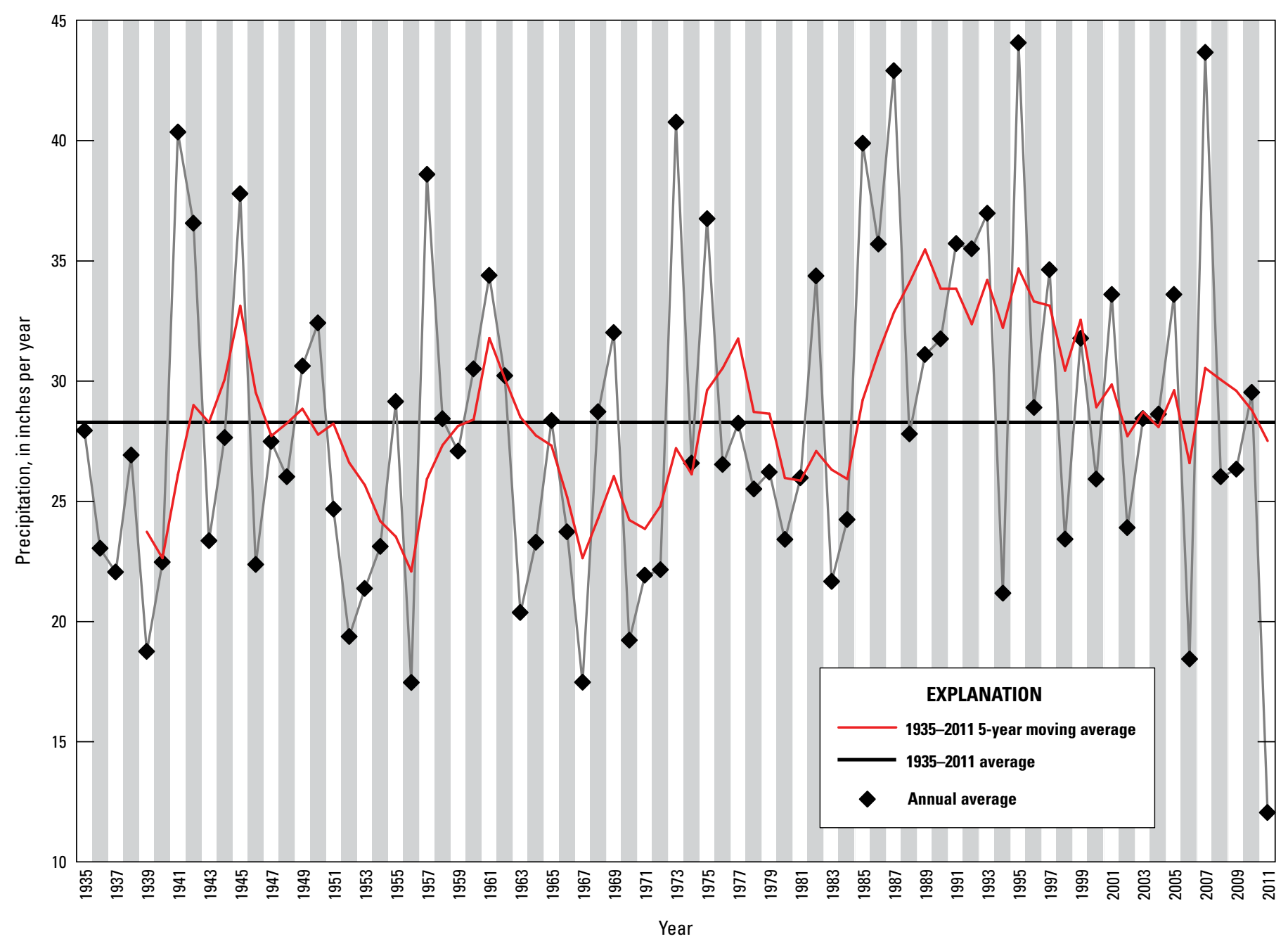

Figure 2. Precipitation for Oklahoma Climatological Survey Climate Division 7 Southwest, 1935-2011.

Water from the Rush Springs aquifer is used for irrigation, public, livestock and aquaculture, and other supply purposes (Tortorelli, 2009; U.S. Geological Survey, 2013). Most of the water use in 2005 was for irrigation (66 percent of total water use); total water use in 2005 was approximately 10,500 million gallons per year (Mgal/yr) (fig. 3). Groundwater from the Rush Springs aquifer also is withdrawn by domestic (self-supplied) wells, as indicated by more than 700 wells completed in Caddo County (Oklahoma Water Resources Board, 2013), although domestic use was not included in the water-use summary in this report. Water-use data are summarized every 5 years by the USGS (Tortorelli, 2009). Groundwater-use data for Caddo County were summarized for 1985-2005. Groundwater use during the 1985-2005 period averaged 13,300 Mgal/yr (40,800 acre-feet per year) (fig. 4). 
Total water use in 2005: 10,500 million gallons (Mgal) (Tortorelli, 2009)

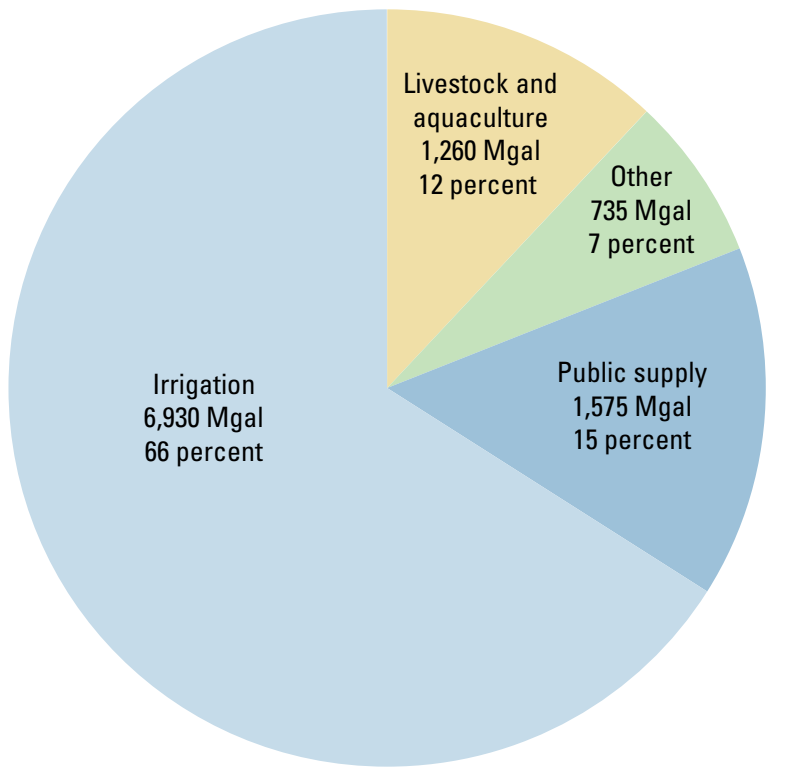

Figure 3. Water use from the Rush Springs aquifer, 2005.

\section{Hydrogeology of the Study Area}

The extent of the Rush Springs aquifer (fig. 1), as defined by Becker and Runkle (1998) and the extent used in this report, is approximately 2,400 square miles $\left(\mathrm{mi}^{2}\right)$. The Rush Springs aquifer is comprised of the Permian-age Rush Springs Formation of the Whitehorse Group (Tanaka and Davis, 1963). Becker and Runkle (1998) limited the extent of the Rush Springs aquifer to areas with the largest groundwater withdrawals. Observations of cores and outcrops in Caddo County indicate that the Rush Springs aquifer is a homogeneous sandstone, with some interbedded dolomite and gypsum. The sandstone is composed of grains of mostly very fine- to fine-grained quartz that are well to moderately sorted. High-angle, cross-bedded sandstone is common in the Rush Springs Formation, indicating eolian deposition (Boggs, 2001). The degree of cementation varies throughout the aquifer, but observations of cores and outcrops indicate the presence of friable, poorly consolidated sandstone. Parts of the Rush Springs Formation have been eroded by runoff from upstream roads, culverts, dams, and rock outcrops to form cavities and plunge pools in surface exposures. These cavities look like canyons with nearly vertical walls and probably were formed from the force of rushing water during flashy precipitation events on friable sandstone.

The Rush Springs aquifer is bound by the erosional extent of the Rush Springs Formation to the east and south. Underlying the Rush Springs Formation and in contact to the east and south is the Marlow Formation of the Whitehorse Group, which is composed of interbedded sandstones, siltstones, mudstones, gypsum-anhydrite, and dolomite

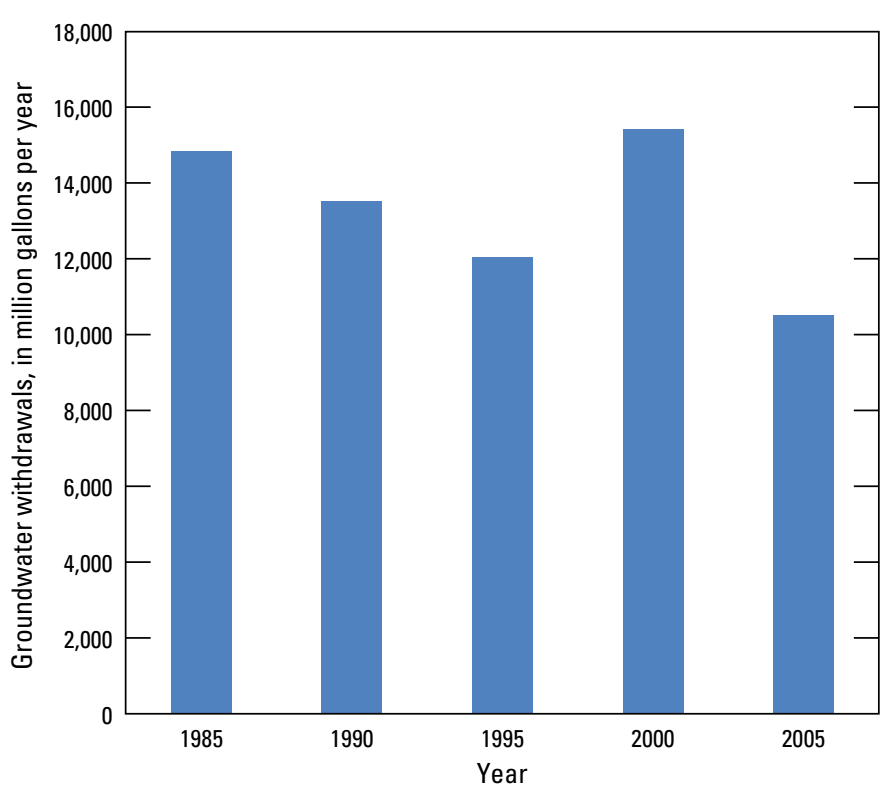

Figure 4. Groundwater withdrawals in Caddo County, Oklahoma, 1985-2005.

(Becker and Runkle, 1998; fig. 1). On the basis of lithology, the Marlow Formation most likely is a confining unit underlying the Rush Springs aquifer. To the west of the study area, the Rush Springs Formation is overlain by the Cloud Chief Formation and Quaternary alluvium and terrace deposits (which form alluvial aquifers). The Cloud Chief Formation is composed of massive gypsum interbedded with reddish-brown mudstone and siltstone (Becker and Runkle, 1998) and most likely acts as a confining unit to the Rush Springs aquifer (Tanaka and Davis, 1963). The Rush Springs Formation extends to the north and west of the study area. The Rush Springs Formation in Caddo, Custer, Dewey, Grady, and Washita Counties has aquifer properties typically providing good well yields and good water quality (Tanaka and Davis, 1963). Beyond these counties, transmissivities of the aquifer decrease and groundwater contains larger concentrations of dissolved solids and sulfates (Tanaka and Davis, 1963), so that water from the formation is not used extensively in those areas.

Alluvium and terrace deposits overlie the Rush Springs aquifer in the study area and are composed mostly of unconsolidated sands, silts, and clays with some gravel. On the basis of lithologies, groundwater is assumed to move readily through the alluvium and terrace deposits. Where the alluvium and terrace deposits overlie the Rush Springs Formation, those deposits are assumed to be in hydraulic connection with the Rush Springs Formation. Where the alluvium and terrace deposits overlie the Cloud Chief Formation, the alluvium and terrace deposits are assumed to not be in hydraulic connection with the Rush Springs Formation. 


\section{Base Flow from the Rush Springs Aquifer}

Several perennial streams originate in the Rush Springs aquifer. Perennial streams are defined as streams that have continuous flow in parts of the streambed all year during years of normal rainfall (Meinzer, 1923). Streams that are perennial indicate that groundwater contributes to streamflows and maintains streamflows during periods of no precipitation and no surface runoff. The part of streamflow sustained primarily by groundwater discharge that is not from runoff or snowmelt is referred to as "base flow."

Historical streamflow data from USGS streamflowgaging stations were retrieved from the National Water Information System (NWIS) and analyzed to determine the base-flow component of streamflow for streams overlying the Rush Springs aquifer. Base flow maintains streamflows throughout the year and, in some cases, provides water for reservoir storage. The amount of base flow that aquifers contribute to streams can change over time and by location in response to varying climatic conditions, such as changes in precipitation and temperature; and in response to increased surface-water use or groundwater use from aquifers in hydraulic connection to streams.
Historical streamflow data were compiled and analyzed by using the PART method (Rutledge, 1998) to determine the base-flow component of streamflow from the Rush Springs aquifer in selected streams overlying the Rush Springs aquifer. The PART method uses streamflow partitioning to estimate daily base flow from the streamflow record and is based on the antecedent streamflow recession (Rutledge, 1998; fig. 5). The PART method is used for the analysis of the groundwater-flow system of a basin for which a streamflow-gaging station at the downstream end can be considered the only point of outflow. One assumption of the PART method is that the area of the contributing groundwater-flow system is equal to the drainage area of the streamflow-gaging station for the purpose of expressing flow in units of specific discharge (length per time). To use the PART method, regulation and diversion of flow should be negligible and the drainage-basin area should be less than $500 \mathrm{mi}^{2}$ (Rutledge, 1998). For this report, negligible regulation for a streamflow-gaging station is defined as having less than 20 percent of the drainage area upstream from a streamflow-gaging station controlled by dams, floodwater-retarding structures, or other human modifications of streamflow.

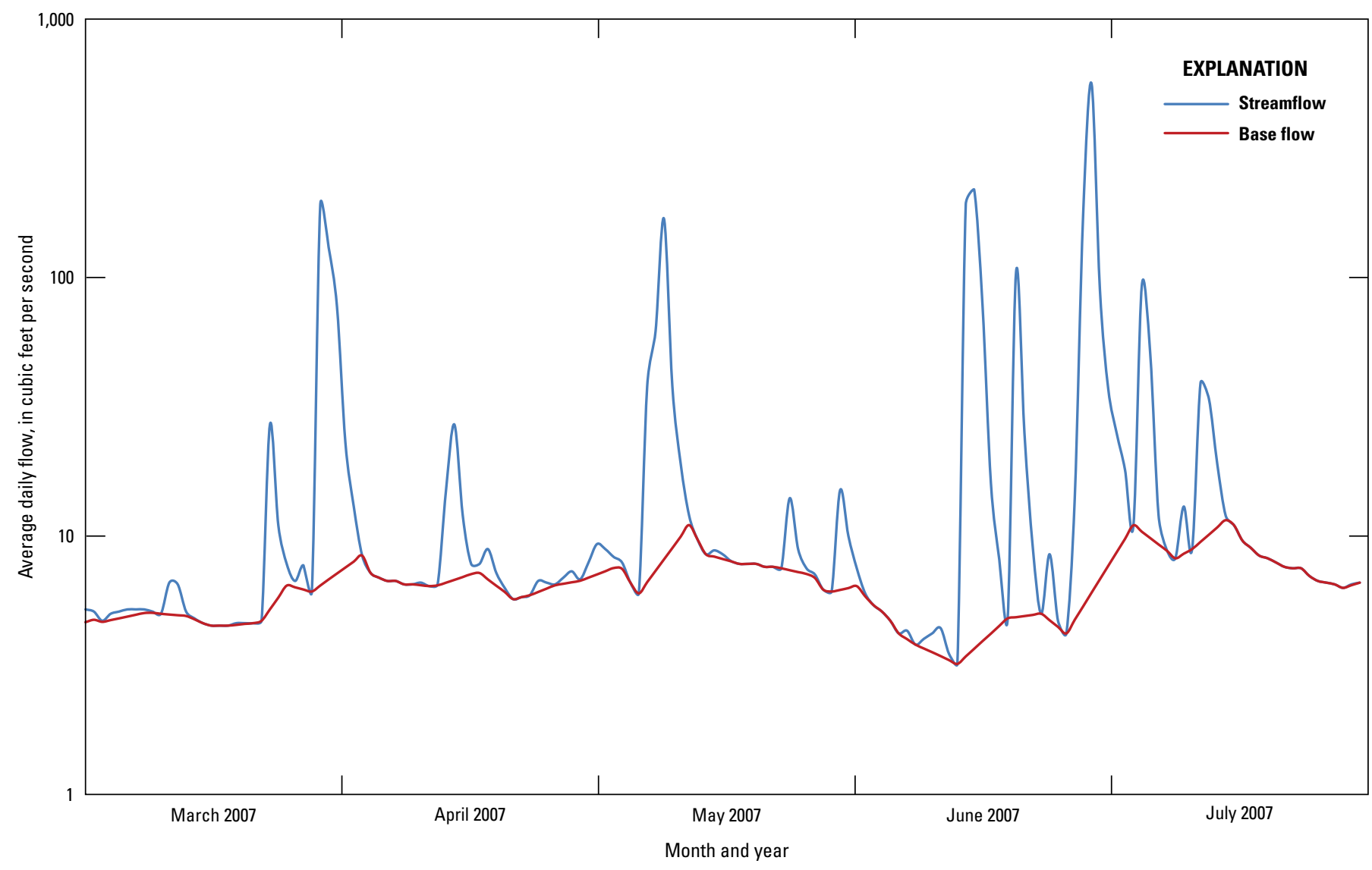

Figure 5. Example of base flow determined by using the PART method (Rutledge, 1998) and streamflow at streamflow-gaging station 07325850 (Lake Creek near Eakly, Oklahoma), March-July 2007. 
Five USGS streamflow-gaging stations located on the Rush Springs aquifer and analyzed by using the PART method to determine base flow (fig. 6 and table 1) included: 07325840 (Lake Creek near Sickles, Okla.), 07325850 (Lake Creek near Eakly, Okla.), 07325860 (Willow Creek near Albert, Okla.), 07326000 (Cobb Creek near Fort Cobb, Okla.), and 073274406 (Little Washita River above SCS Pond No. 26 near Cyril, Okla.). Unregulated streamflow data for streamflowgaging station 07325840 (Lake Creek near Sickles, Okla.) were available from 2006 through 2012, with daily mean streamflow for that period being 4.2 cubic feet per second $\left(\mathrm{ft}^{3} / \mathrm{s}\right)$ (U.S. Geological Survey, 2013; fig. 7). Daily mean streamflow is the calculated mean of the streamflow readings for the given day; most streamflow-gaging stations record every 15 or 30 minutes. Results from the PART method for the 2006-12 period indicate that the annual base-flow index for this streamflow-gaging station ranged from 0.3 in 2007 to 0.86 in 2010 (fig. 8). The base-flow index is the ratio of base flow to total streamflow. Monthly mean base flow, runoff, and streamflow were calculated for the 2006-12 period by using results of the PART method and subtracting base flow from streamflow to determine runoff. Monthly mean streamflows for the 2006-12 period indicate that streamflows were composed mostly of base flow during the months of January, February, April, July, September, November, and December (fig. 8). Monthly mean streamflows during the months of March, May, and October indicate that base flow was about equal to runoff. Streamflows were composed mostly of runoff during the months of June and August. Streamflows at this site decreased to zero during July 2006, July through September 2011, and July through September 2012 (fig. 7). These periods of zero flow most likely are related to relatively long periods of no precipitation (fig. 2). Other potential causes in the decline of streamflow during the summer are water use and evaporation from streams and withdrawals from the Rush Springs aquifer or from the overlying alluvial aquifer. 

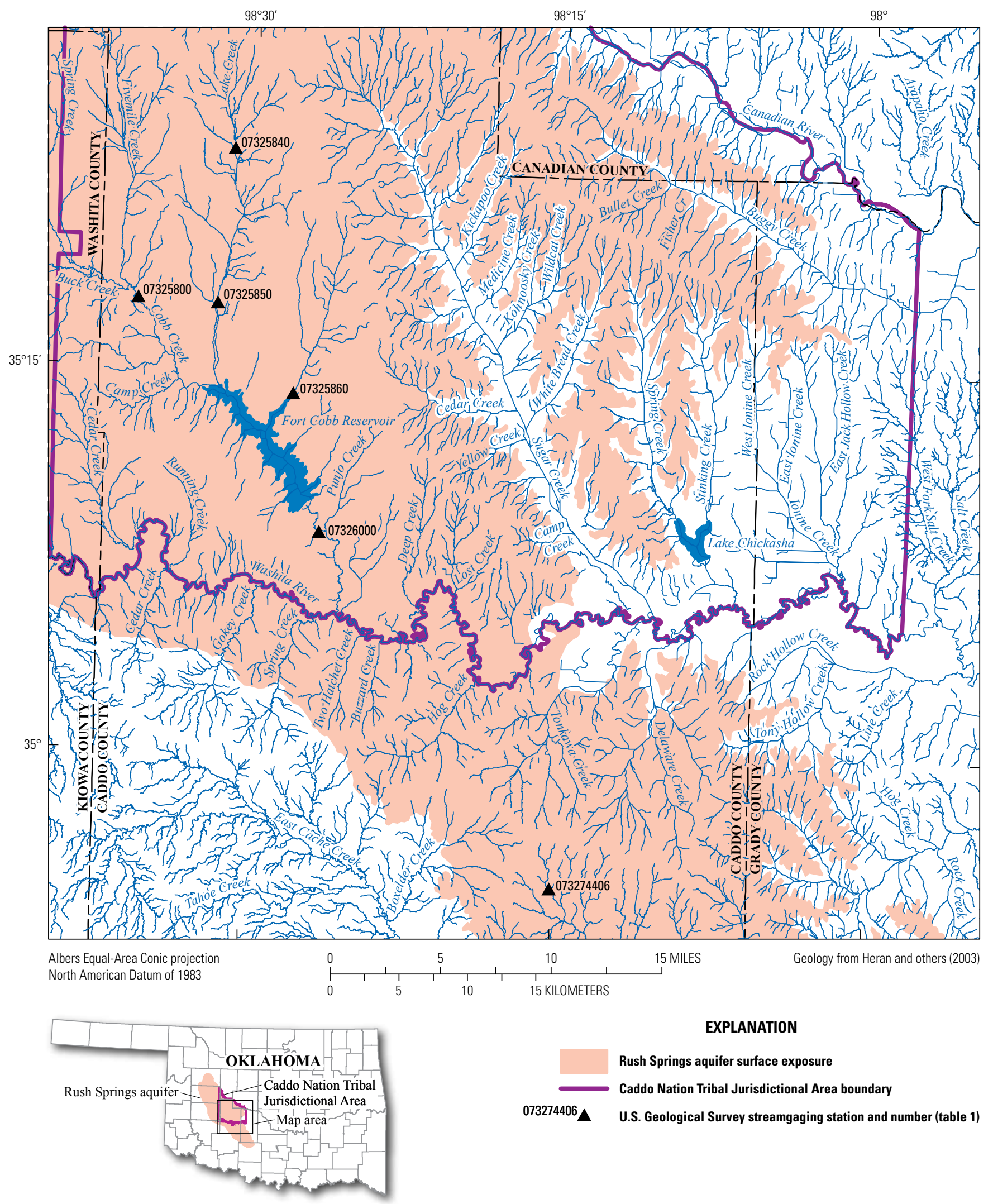

EXPLANATION

Figure 6. Location of U.S. Geological Survey streamflow-gaging stations in the vicinity of the Rush Springs aquifer. 
Table 1. List of streamflow-gaging stations located near the Rush Springs aquifer, southwestern Oklahoma, with periods analyzed using the PART method (Rutledge, 1998).

[The PART method uses streamflow partitioning to estimate daily base flow from the streamflow record and is based on antecedent streamflow recessions; SCS, Soil Conservation Service]

\begin{tabular}{llcc}
\hline $\begin{array}{c}\text { Station } \\
\text { number } \\
\text { (see fig. 6) }\end{array}$ & \multicolumn{1}{c}{ Site name } & $\begin{array}{c}\text { Contributing } \\
\text { drainage area } \\
\text { (square miles) }\end{array}$ & $\begin{array}{c}\text { Unregulated period } \\
\text { analyzed by PART method }\end{array}$ \\
\hline 07325840 & Lake Creek near Sickles, Okla. & 19.1 & $2006-12$ \\
07325850 & Lake Creek near Eakly, Okla. & 52.5 & $1970-77$ and 2005-12 \\
07325860 & Willow Creek near Albert, Okla. & 28.2 & $1971-77$ and 2005-12 \\
07326000 & Cobb Creek near Fort Cobb, Okla. & 311 & $1940-58$ \\
073274406 & Little Washita River above SCS Pond No 26 near Cyril, Okla. & 3.65 & $1996-2012$ \\
\hline
\end{tabular}

${ }^{1}$ U.S. Geological Survey, 2013.

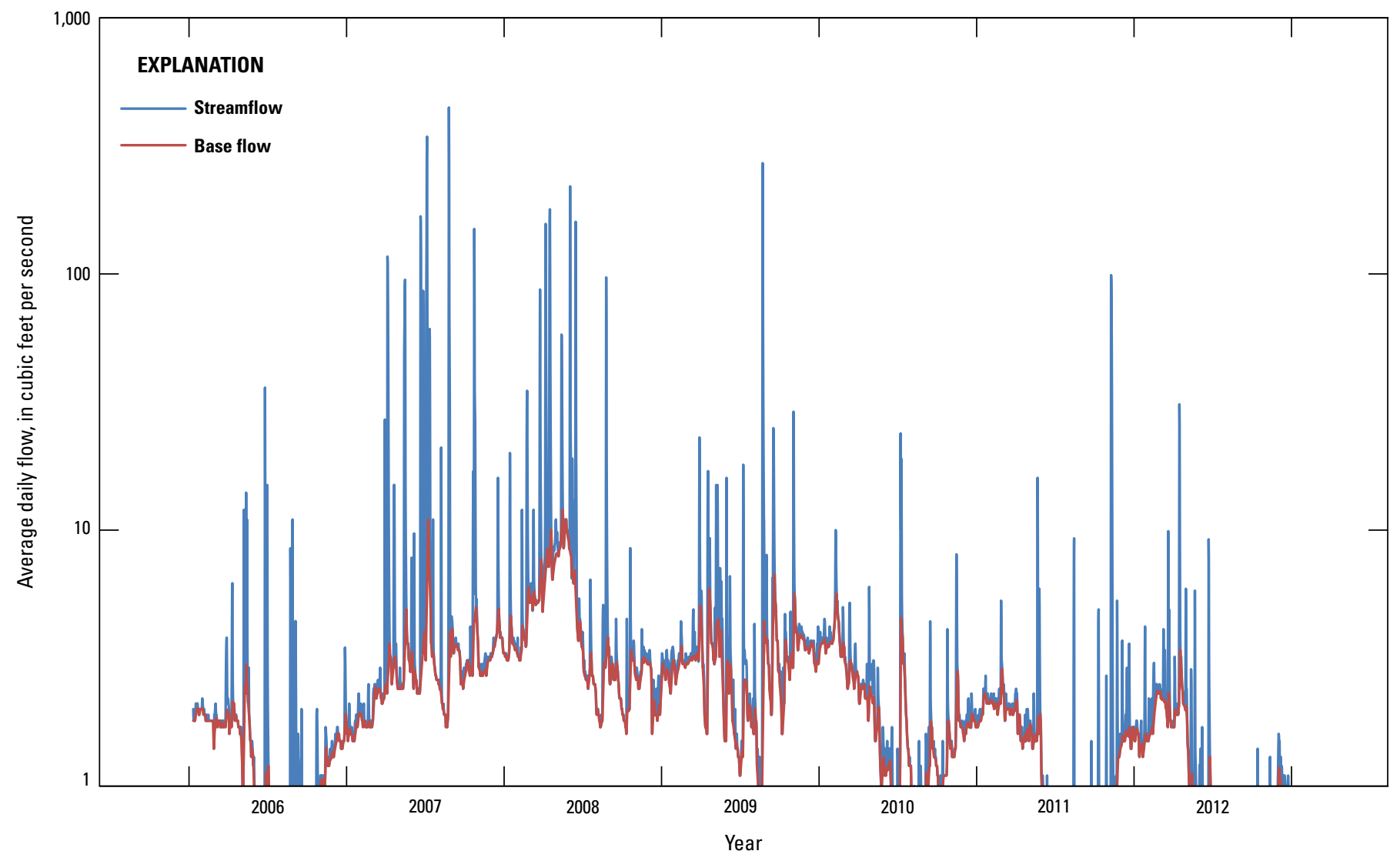

Figure 7. Daily streamflow and base flow derived by using the PART method (Rutledge, 1998) for streamflow-gaging station 07325840 (Lake Creek near Sickles, Oklahoma), 2006-12. 

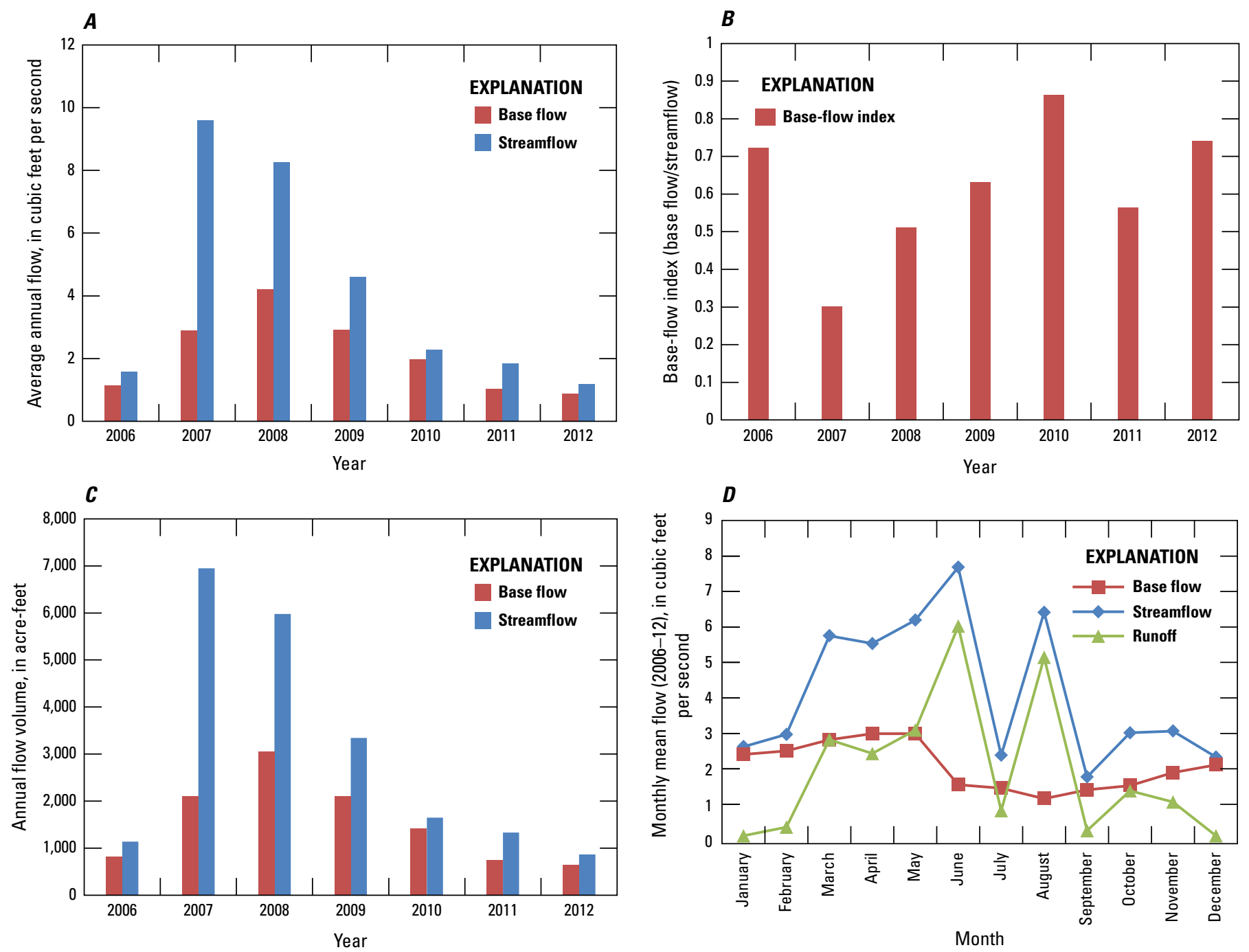

Figure 8. $(A)$ average annual streamflow and base flow, $(B)$ base-flow index, $(C)$ average annual streamflow and base-flow volume, and $(D)$ monthly mean streamflow, base flow, and runoff at streamflow-gaging station 07325840 (Lake Creek near Sickles, Oklahoma), 2006-12. 
Unregulated streamflow data for streamflow-gaging station 07325850 (Lake Creek near Eakly, Okla.) were available for the periods 1970-77 and 2005-12. For the 197077 period, daily mean streamflow was $7.4 \mathrm{ft}^{3} / \mathrm{s}$ (fig. 9). Results from the PART method for the 1970-77 period indicate that the annual base-flow index for this streamflow-gaging station ranged from 0.16 in 1977 to 0.55 in 1976 (fig. 10). Monthly mean streamflows for the 1970-77 period indicate that streamflows were composed mostly of runoff for the months of March, May, June, July, August, September, October, and
November (fig. 10). Monthly mean streamflows indicate that streamflows were composed mostly of base flow for the months of January, February, and April. Monthly mean flows during December indicate that base flow was about equal to runoff. Streamflows declined to zero from May to September during the years 1970-74 (fig. 9). The precipitation graph (fig. 2) indicates that 1973 and 1975 were years of aboveaverage precipitation. Streamflows during 1973 declined to zero in late July through August; streamflows during 1975 never reached zero at this station.

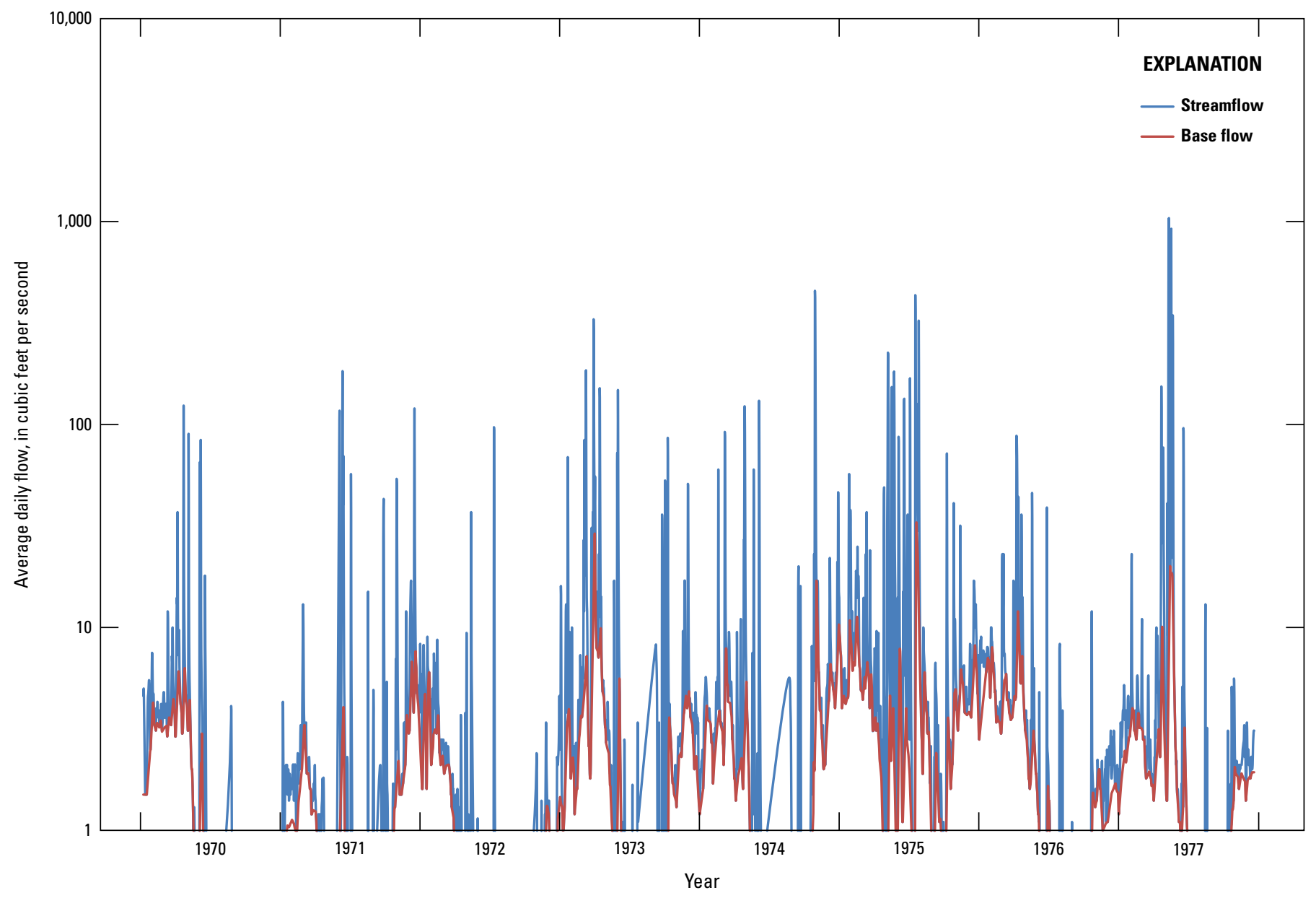

Figure 9. Daily streamflow and base flow derived by using the PART method (Rutledge, 1998) for streamflow-gaging station 07325850 (Lake Creek near Eakly, Oklahoma), 1970-77. 

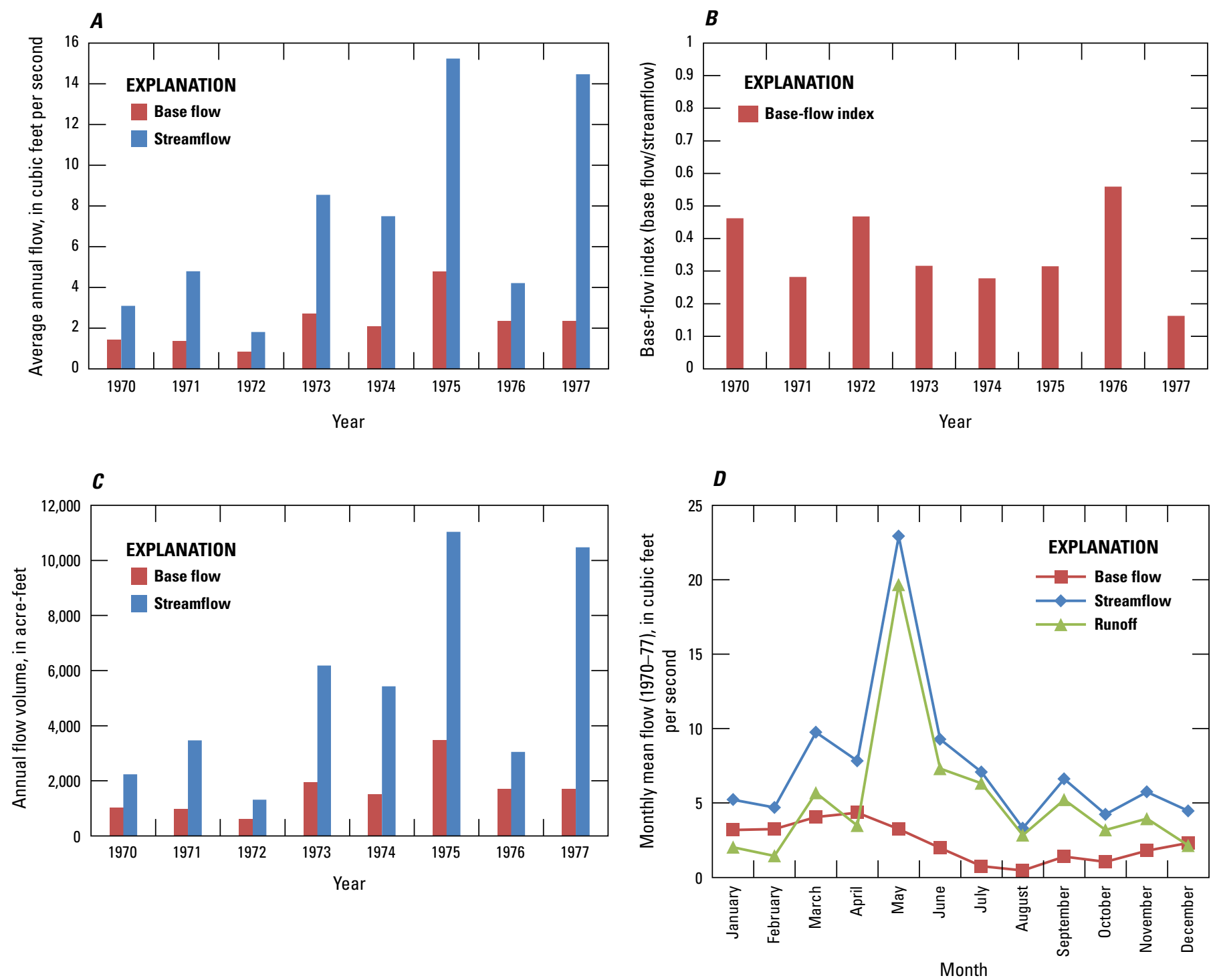

Figure 10. $(A)$ average annual streamflow and base flow, $(B)$ base-flow index, $(C)$ average annual streamflow and base-flow volume, and $(D)$ monthly mean streamflow, base flow, and runoff at streamflow-gaging station 07325850 (Lake Creek near Eakly, 0klahoma), 1970-77. 
For the 2005-12 period, daily mean streamflow was $9.3 \mathrm{ft}^{3} / \mathrm{s}$ (fig. 11). Results from the PART method for the 2005-12 period indicate that the annual base-flow index for this streamflow-gaging station ranged from 0.3 in 2007 to 0.85 in 2010 (fig. 12). Monthly mean streamflows for the 2005-12 period indicate that streamflows were composed mostly of base flow from January to May, from September to December, and during July (fig. 12). Streamflows were composed mostly of runoff during the months of June and August for the 200512 period. Streamflows never declined to zero during the 2005-12 period but were close to zero at $0.08 \mathrm{ft}^{3} / \mathrm{s}$ in August 2011 and August 2012 at this station (fig. 11).

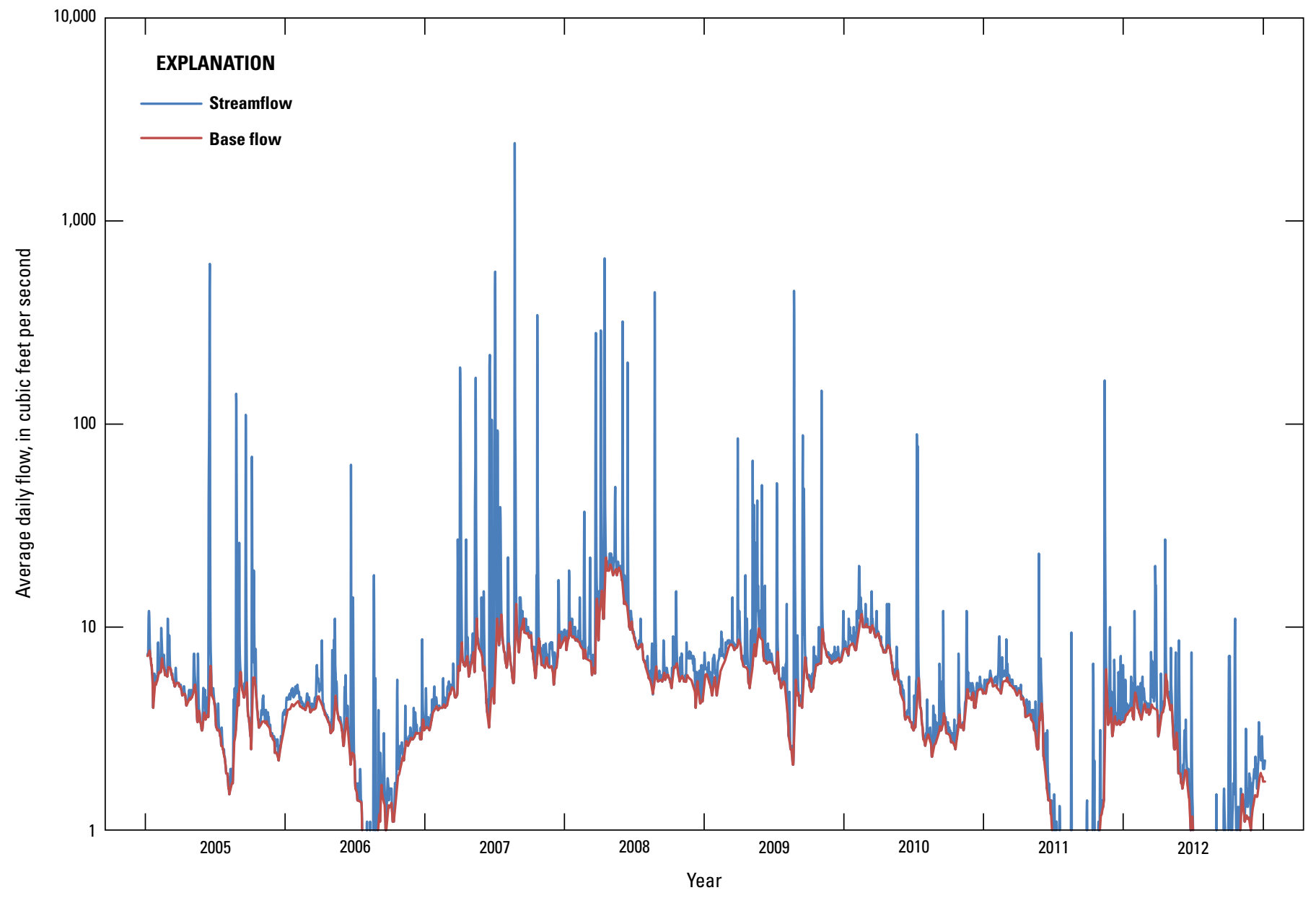

Figure 11. Daily streamflow and base flow derived by using the PART method (Rutledge, 1998) for streamflow-gaging station 07325850 (Lake Creek near Eakly, Oklahoma), 2005-12. 

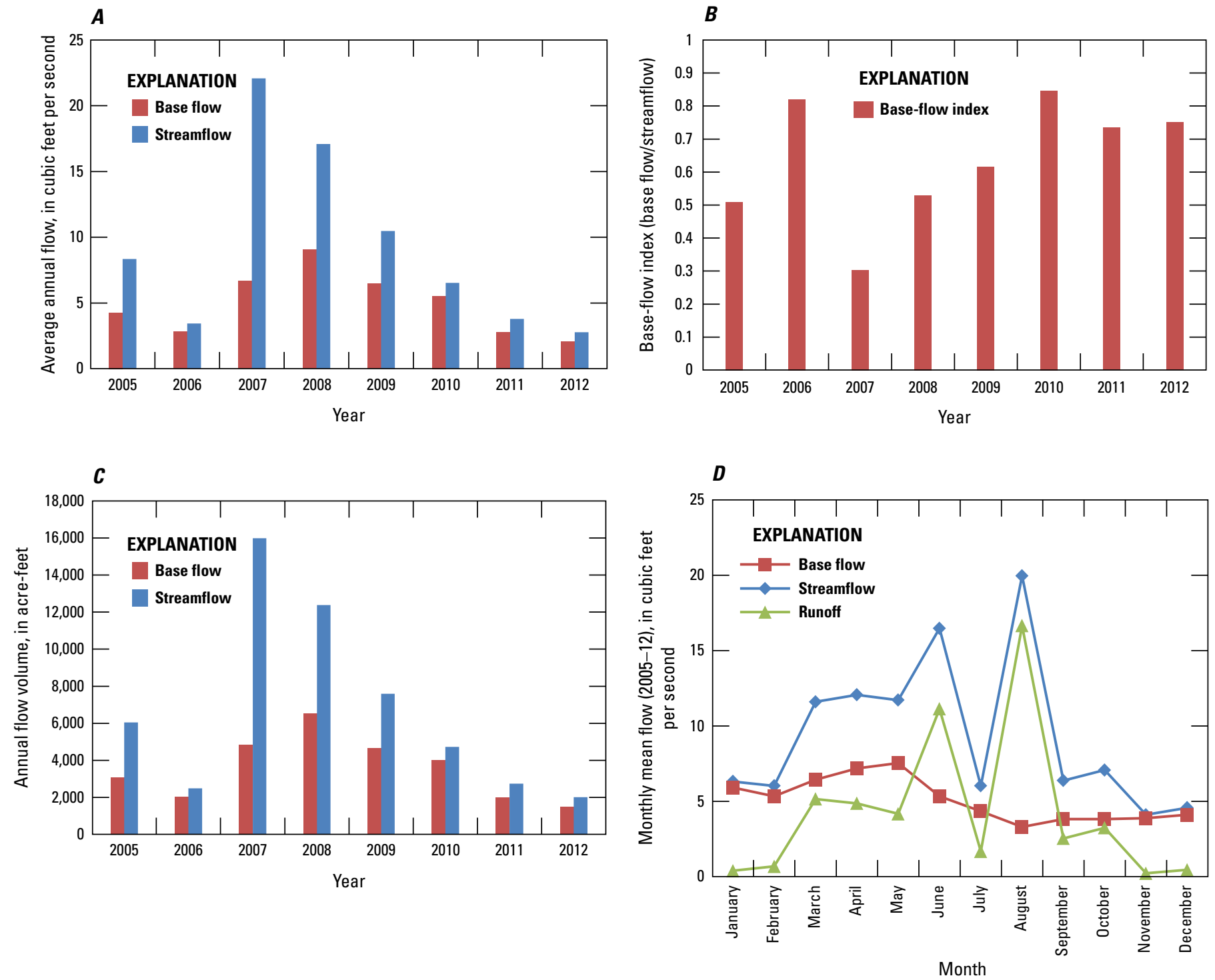

Figure 12. $(A)$ average annual streamflow and base flow, $(B)$ base-flow index, $(C)$ average annual streamflow and base-flow volume, and $(D)$ monthly mean streamflow, base flow, and runoff at streamflow-gaging station 07325850 (Lake Creek near Eakly, Oklahoma), 2005-12. 
Unregulated streamflow data for streamflow-gaging station 07325860 (Willow Creek near Albert, Okla.) were available for the periods 1971-77 and 2005-12. For the 1971-77 period, daily mean streamflow was $4.1 \mathrm{ft}^{3} / \mathrm{s}$ (fig. 13). Results from the PART method for the 1971-77 period indicate that the annual base-flow index for this streamflow gaging station ranged from 0.14 in 1977 to 0.80 in 1976 (fig. 14). Monthly mean streamflows for the 1971-77 period indicate that streamflows were composed mostly of runoff for the months of May, June, July, and August (fig. 14). Monthly mean streamflows indicate that streamflows were composed mostly of base flow for the months of January, February, April, October, and December. Monthly mean streamflows indicate that base flow was about equal to runoff for the months of March, September, and November. Streamflows declined to zero for periods of 3-10 days during the months of August through October 1972, July 1974, and August 1976 at this station (fig. 13).

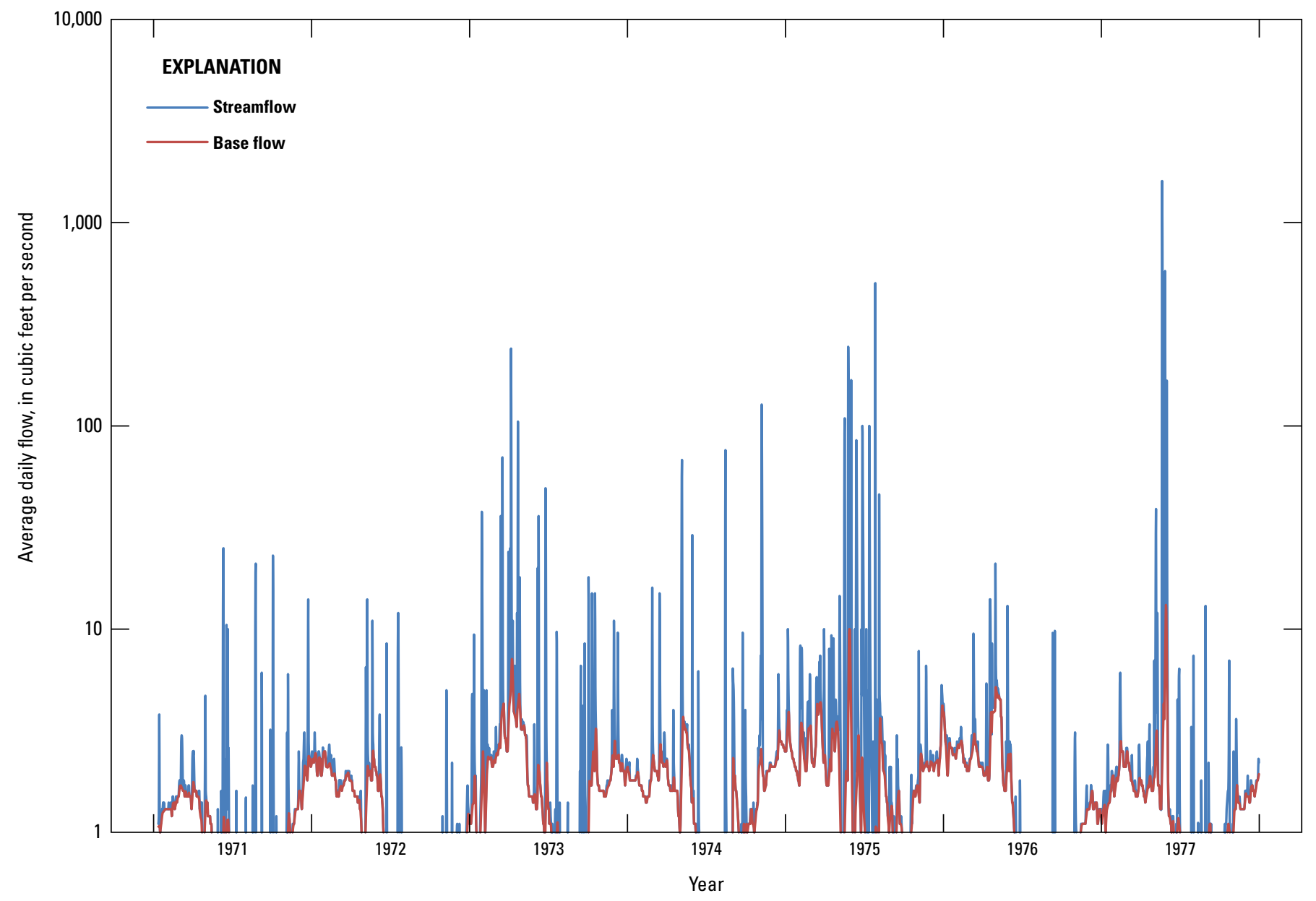

Figure 13. Daily streamflow and base flow derived by using the PART method (Rutledge, 1998) for streamflow-gaging station 07325860 (Willow Creek near Albert, Oklahoma), 1971-77. 

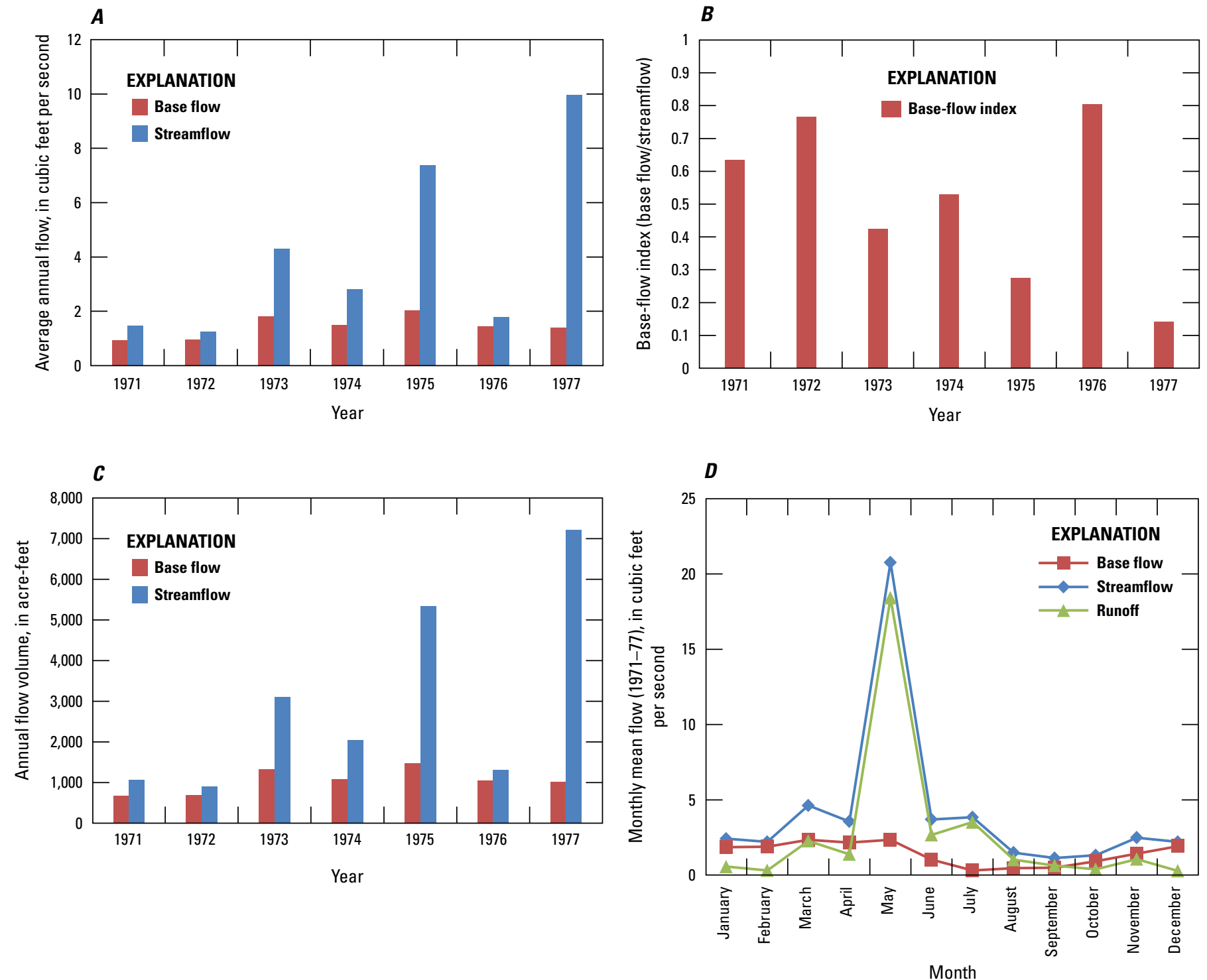

Figure 14. $(A)$ average annual streamflow and base flow, $(B)$ base-flow index, $(C)$ average annual streamflow and base-flow volume, and $(D)$ monthly mean streamflow, base flow, and runoff at streamflow-gaging station 07325860 (Willow Creek near Albert, Oklahoma), $1971-77$. 
For the 2005-12 period, daily mean streamflow for streamflow-gaging station 07325860 (Willow Creek near Albert, Okla.) was $4.0 \mathrm{ft}^{3} / \mathrm{s}$ (fig. 15). Results from the PART method for the 2005-12 period indicate that the annual base-flow index for this streamflow-gaging station ranged from 0.42 in 2007 to 0.90 in 2006 (fig. 16). Monthly mean streamflows for the 2005-12 period indicate that streamflows were composed mostly of base flow for the months of January,
February, March, April, May, July, September, October, November, and December (fig. 16). The month of August was the only month that streamflows were composed mostly of runoff. Monthly mean streamflows indicate that base flow was about equal to runoff for the month of June. Streamflows never declined to zero during the 2005-12 period but were close to zero at $0.1 \mathrm{ft}^{3} / \mathrm{s}$ in September 2012 (fig. 15).

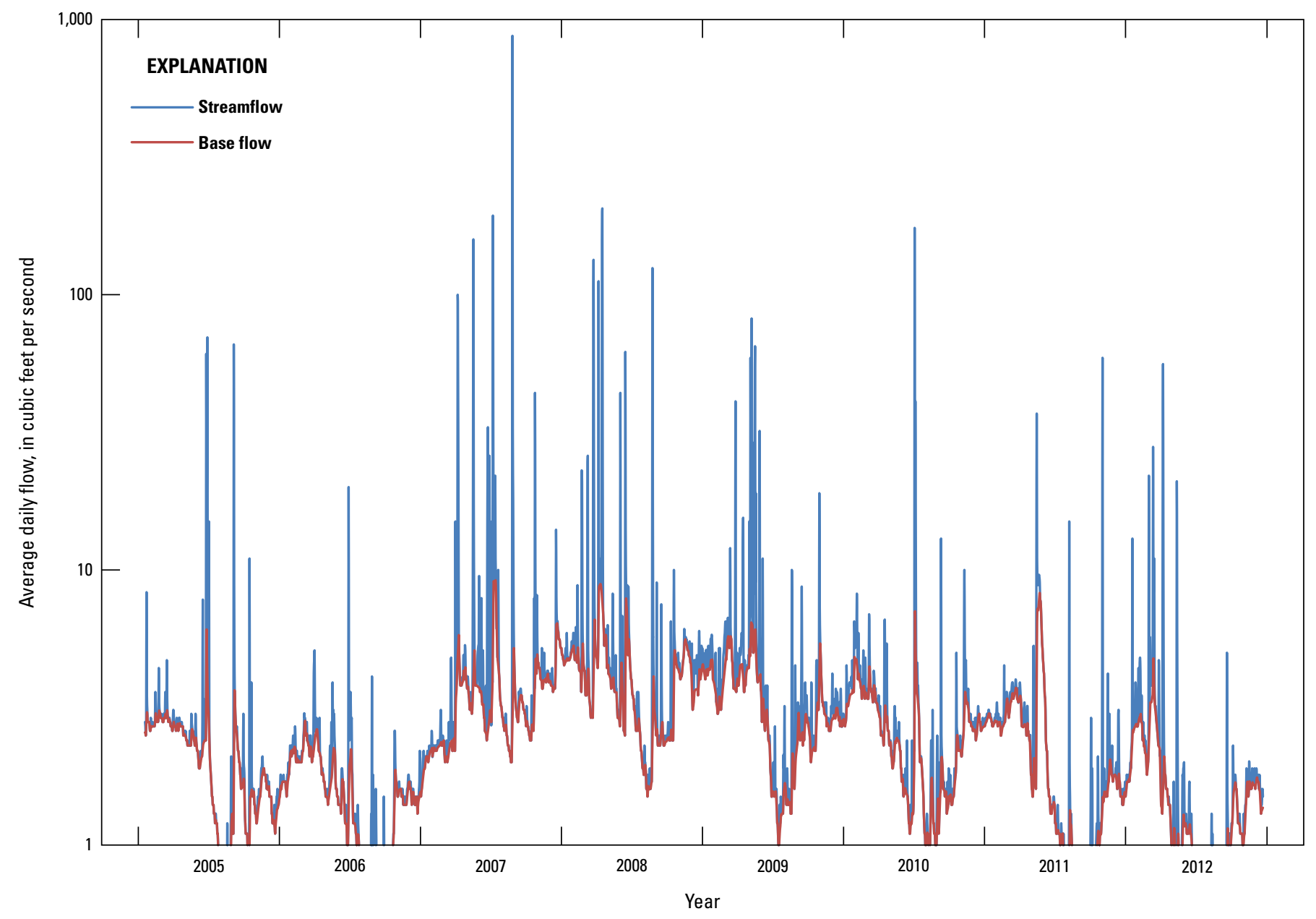

Figure 15. Daily streamflow and base flow derived by using the PART method (Rutledge, 1998) for streamflow-gaging station 07325860 (Willow Creek near Albert, Oklahoma), 2005-12. 

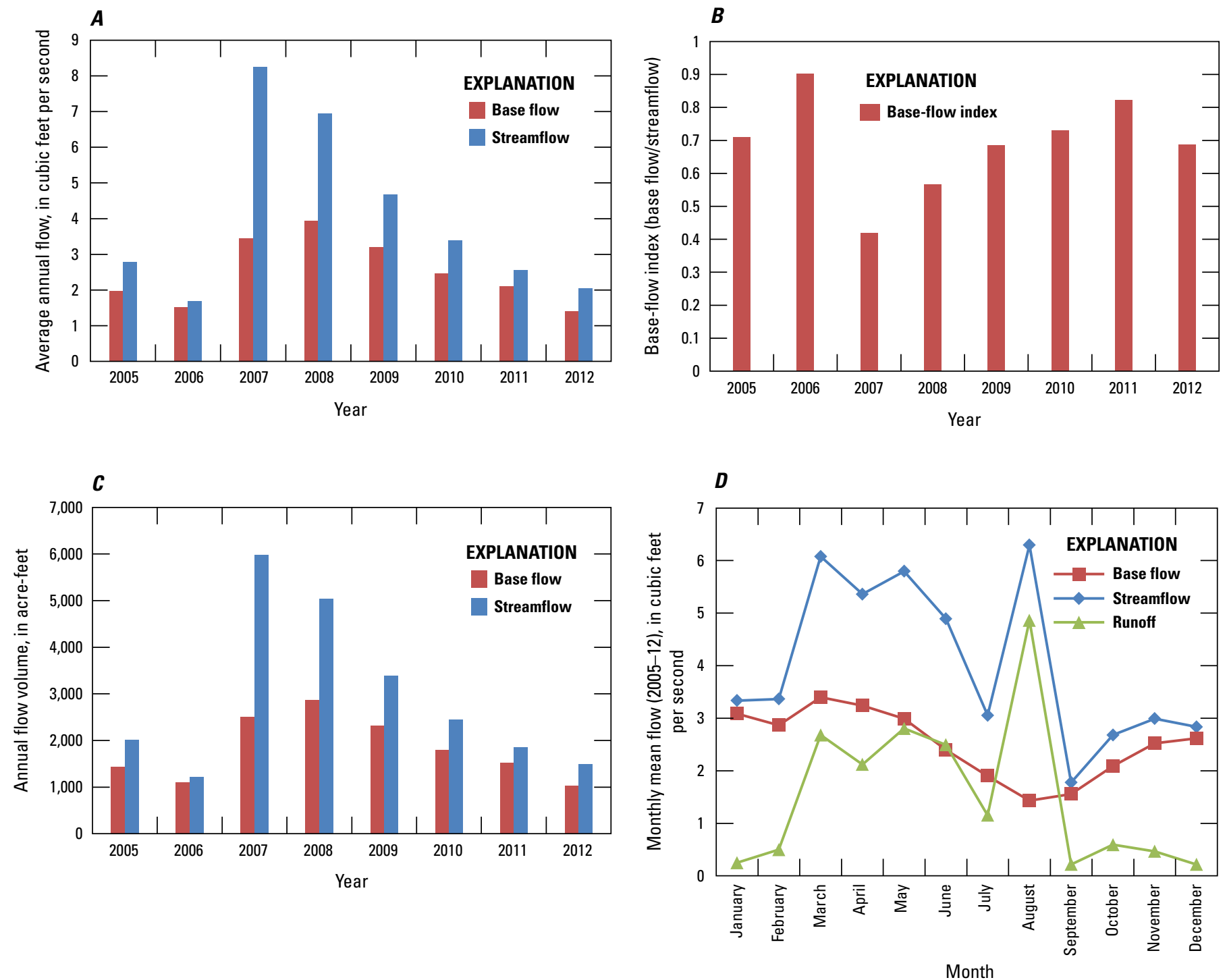

Figure 16. $(A)$ average annual streamflow and base flow, $(B)$ base-flow index, $(C)$ average annual streamflow and base-flow volume, and $(D)$ monthly mean streamflow, base flow, and runoff at streamflow-gaging station 07325860 (Willow Creek near Albert, Oklahoma), 2005-12. 
Unregulated streamflow data for streamflow-gaging station 07326000 (Cobb Creek near Fort Cobb, Okla.) were available for the period 1940-58. For the 1940-58 period, daily mean streamflow was $50 \mathrm{ft}^{3} / \mathrm{s}$ (fig. 17). Results from the PART method for the 1940-58 period indicate that the annual base-flow index for this streamflow-gaging station ranged from 0.27 in 1949 to 0.78 in 1956 (fig. 18). Monthly mean streamflows for the $1940-58$ period indicate that streamflows were composed mostly of base flow for the months of January, February, March, November, and December (fig. 18). Monthly mean streamflows indicate that streamflows were composed mostly of runoff for the months of April, May, June, and July. Monthly mean streamflows indicate that base flow was relatively equal to runoff for the months of August, September, and October. Streamflows never declined to zero during the 1940-58 period but were close to zero at $0.2 \mathrm{ft}^{3} / \mathrm{s}$ in September 1956 at this station (fig. 17).

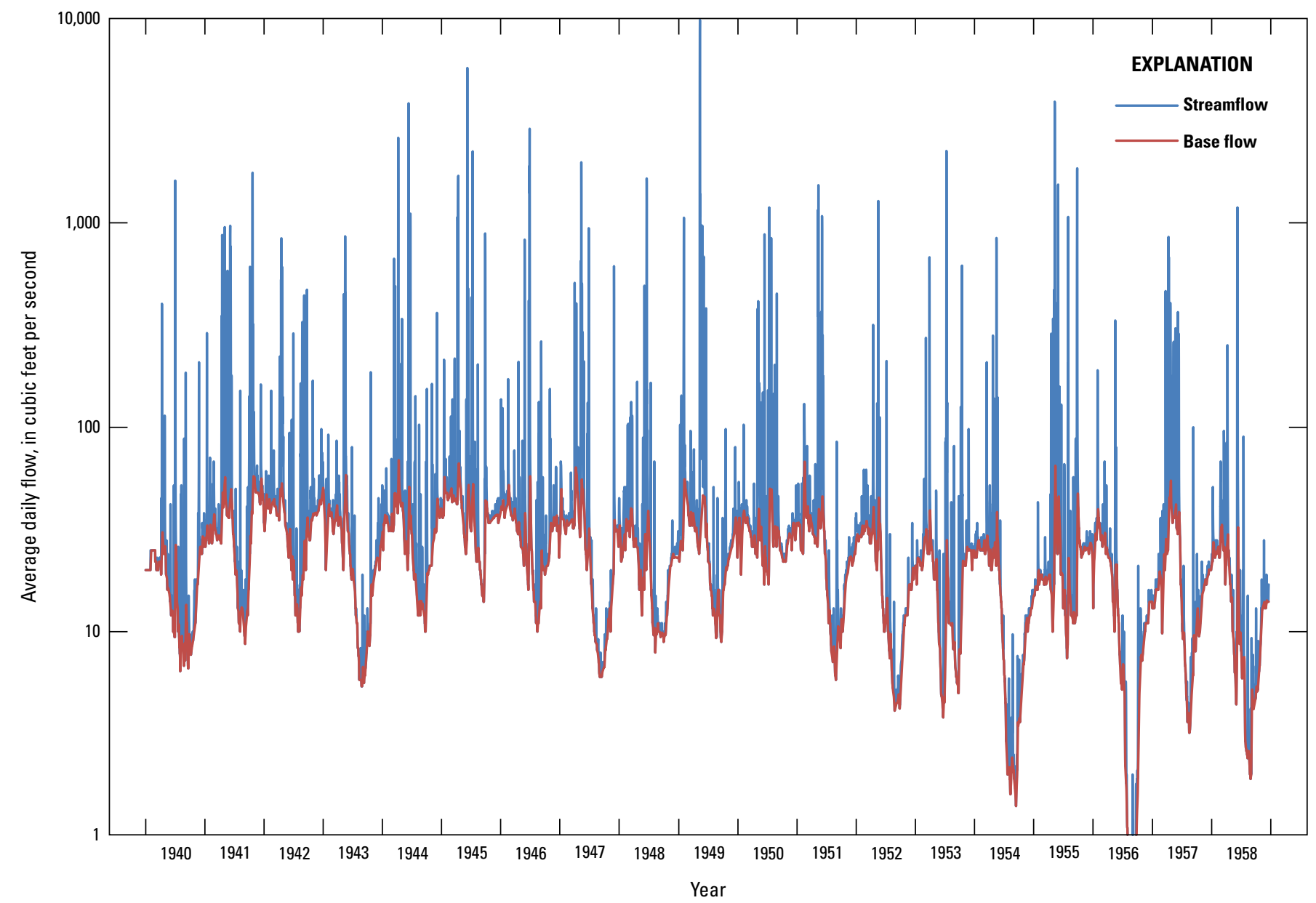

Figure 17. Daily streamflow and base flow derived by using the PART method (Rutledge, 1998) for streamflow-gaging station 07326000 (Cobb Creek near Fort Cobb, 0klahoma), 1940-58. 

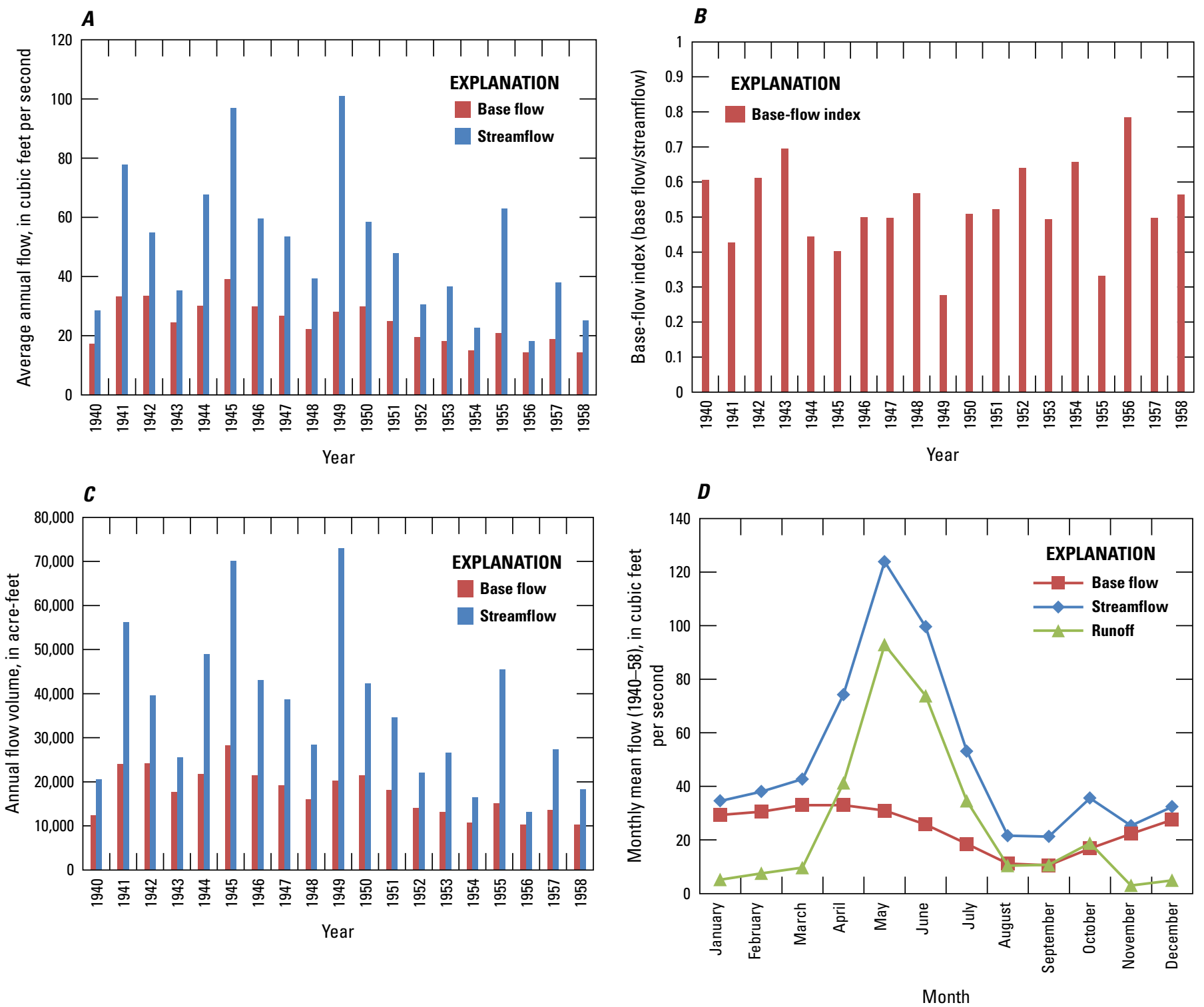

Figure 18. $(A)$ average annual streamflow and base flow, $(B)$ base-flow index, $(C)$ average annual streamflow and base-flow volume, and $(D)$ monthly mean streamflow, base flow, and runoff at streamflow-gaging station 07326000 (Cobb Creek near Fort Cobb, 0klahoma), $1940-58$. 
Unregulated streamflow data for streamflow gagingstation 073274406 (Little Washita River above SCS [Soil Conservation Service] Pond No. 26 near Cyril, Okla.) were available for the period 1996-2012. For the 1996-2012 period, daily mean streamflow was $1.4 \mathrm{ft}^{3} / \mathrm{s}$ (fig. 19). Results from the PART method for the 1996-2012 period indicate that the annual base-flow index for this streamflow-gaging station ranged from 0.19 in 2006 to 0.89 in 2001 (fig. 20). Monthly mean streamflows for the 1996-2012 period indicate that streamflows were composed mostly of base flow for the months of January, February, March, April, May, July, November, and December (fig. 20). Monthly mean streamflows indicate that streamflows were composed mostly of runoff for the months of June, August, and October. Monthly mean streamflows indicate that base flow was about equal to runoff for the month of September. Because the drainage area for this basin is smaller than the other stations (table 1), streamflows decrease to zero more frequently than at the other stations. Zero flow was documented for several days in the months of October 2003, May through September 2004, June through August 2006, July through September 2011, and August 2012 at this station (fig. 19).

Flows in streams overlying the Rush Springs aquifer, on average, are composed of 50 percent base flow for most years. Base flow appears to maintain streamflows throughout each year, but periods of zero flow were documented in the daily hydrographs for most of the sites and typically occurred in the summer months. These streams are not always perennial and periods of zero flow coincided with relatively long periods of no precipitation. Other potential causes in the decrease of streamflow during the summer are surface-water use and evaporation from streams and groundwater use from the Rush Springs aquifer or the overlying alluvial aquifer.

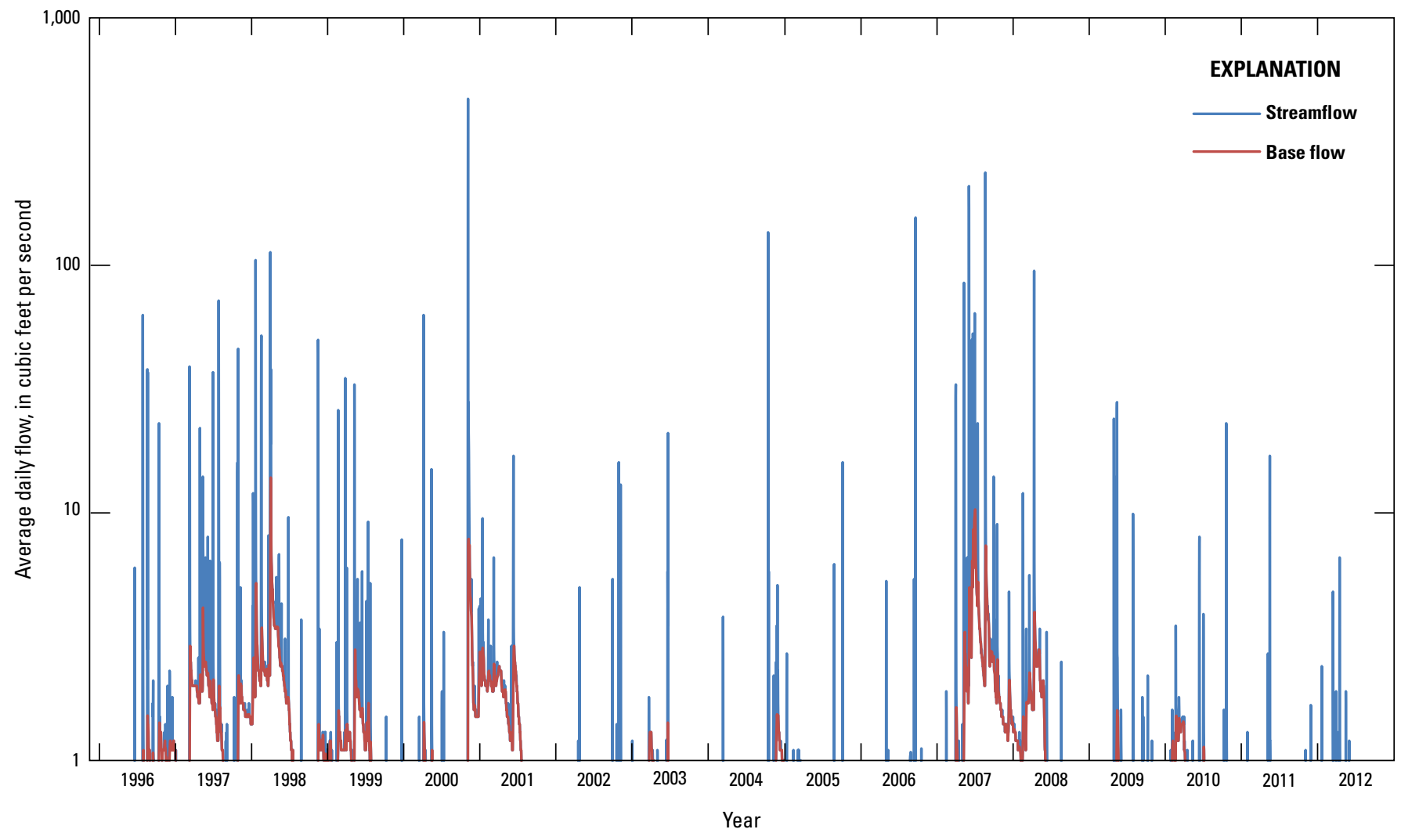

Figure 19. Daily streamflow and base flow derived by using the PART method (Rutledge, 1998) for streamflow-gaging station 073274406 (Little Washita River above SCS [Soil Conservation Service] Pond No. 26 near Cyril, Oklahoma), $1996-2012$. 

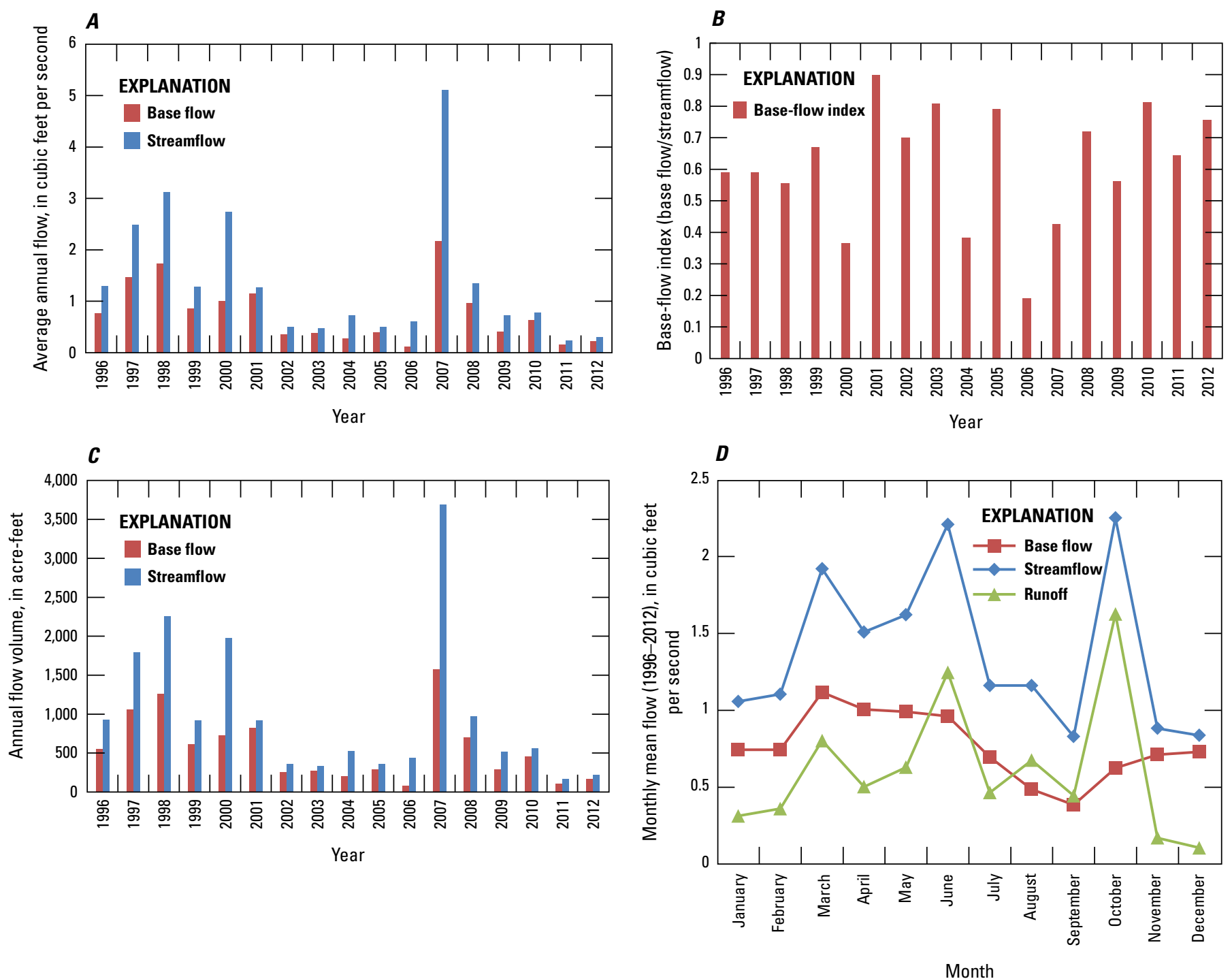

Figure 20. $(A)$ average annual streamflow and base flow, $(B)$ base-flow index, $(C)$ average annual streamflow and base-flow volume, and $(D)$ monthly mean streamflow, base flow, and runoff at streamflow-gaging station 073274406 (Little Washita River above SCS [Soil Conservation Service] Pond No. 26 near Cyril, Oklahoma), 1996-2012. 


\section{Interaction between Groundwater and Surface Water of the Rush Springs Aquifer}

The flow of water between groundwater and surface water can be described by using qualitative and quantitative methods. Direct and indirect methods can be used for quantifying flow between groundwater and surface water. For this report, direct and indirect methods were used, including the following: (1) hydraulic conductivity of streambed sediments was quantified to determine the potential and magnitude of flow between the stream and the Rush Springs aquifer, (2) hydraulic-head gradients were measured during the summer of 2012 between selected streams and alluvium to determine direction and magnitude of flow, (3) volumetric flow rates were quantified by using seepage meters installed in streambed sediments, and (4) water levels in the alluvium and stream were monitored at a streamflow-gaging station to show changes in flow between surface water and groundwater over time throughout a year.

\section{Streambed Hydraulic Conductivity}

Streambed hydraulic conductivity is defined in this report as the horizontal hydraulic conductivity of the streambed sediments underlying the stream and overlying the Rush Springs aquifer. A pneumatic slug-test technique was used to determine the horizontal hydraulic conductivity of streambed sediments in streams overlying the Rush Springs aquifer. The slug-test method measures horizontal hydraulic conductivity as a function of the response of the water level in a well to a displacement following the methods of Hinsby and others (1992), Zlotnik (1994), Zlotnik and others (1998), and Rus and others (2001). By estimating anisotropic conditions typical of streambed sediments, horizontal hydraulic conductivity can be used to estimate vertical hydraulic conductivity. Vertical streambed hydraulic conductivity is one of the properties that controls groundwater/surfacewater interactions between a stream and aquifer. In addition, streambed hydraulic conductivity is an important parameter in numerical groundwater-flow models needed to model the flux of groundwater across a stream/aquifer interface.

Streambed hydraulic conductivity was measured by a slug-test technique at 15 sites along Cobb Creek, Fivemile Creek, Lake Creek, Willow Creek, Keechi Creek, and Sugar Creek during July and August 2012 (fig. 21 and table 2). Initially, streambed hydraulic conductivity was to be measured at 30 sites overlying the Rush Springs aquifer, including reaches along Wildcat Creek, White Bread Creek, Medicine Creek, and Kickapoo Creek (see fig. 1 for locations of creeks), but most of these stream reaches were dry during July and August 2012, and could not be slug tested without saturated sediments. Temporary, small-diameter wells (with an inside diameter of $0.0521 \mathrm{ft}$ ) were pushed into the streambed sediments by using a mallet until refusal point or until water entered the well. A series of slug tests were performed at each depth to ensure that at least one of the tests contained observable water-level responses from the induced pressure changes. The wells were initially pumped by using tubing and a peristaltic pump to remove fine particle well skins from around the screen, and afterward, the water level was allowed to return to static level. The recovery rates in each well were relatively quick (30-60 seconds), so air pressure (pneumatic method) was used to displace the water in each well for the slug test (fig. 22). Water levels were monitored every second throughout the slug test by a submersible pressure transducer attached to a data logger. The slug test responses were analyzed by using the AQuifer TEst SOLVer (AQTESOLV) software package (Hydrosolve, Inc., 2011) and were matched to an analytical solution.

Analytical solutions have been developed for various aquifer types under a variety of hydraulic conditions, and these analytical solutions have been published in previous reports and articles. Water-level data from slug tests can be entered into AQTESOLV software, and AQTESOLV can be used to match water-level data to previously published analytical solutions. Each of these analytical solutions has several assumptions that must be considered when determining a good fit between the water-level data and the analytical solution.

Slug-test data were input into AQTESOLV software to match an analytical solution provided in the software. Twelve of the slug tests were matched to the Springer-Gelhar solution (Springer and Gelhar, 1991). Two of the slug tests were matched to the Bouwer-Rice solution (Bouwer, 1989; Bouwer and Rice, 1976), and one of the slug tests was matched to the Kansas Geological Survey (KGS) Model with Skin solution (Hyder and others, 1994).

The Bouwer-Rice solution (Bouwer and Rice, 1976) was developed for an overdamped slug test in a fully or partially penetrating well in an unconfined aquifer. The assumptions for the Bouwer-Rice solution are as follows: (1) the aquifer has infinite areal extent, (2) the aquifer is homogeneous and of uniform thickness, (3) the aquifer is unconfined, (4) flow to the well is quasi-steady state, and (5) volume of water is injected into or discharged from the well instantaneously.

The Springer-Gelhar solution (Springer and Gelhar, 1991) extended the Bouwer-Rice solution for a slug test in a homogeneous, anisotropic, unconfined aquifer to include inertial effects in the test well. This solution accounts for oscillatory water-level response that is sometimes observed in aquifers of high hydraulic conductivity. In addition, on the basis of the work of Butler (2002), frictional well loss in small-diameter wells is incorporated in the Springer-Gelhar solution. The assumptions for the Springer-Gelhar solution are similar to the assumptions of the Bouwer-Rice solution. 

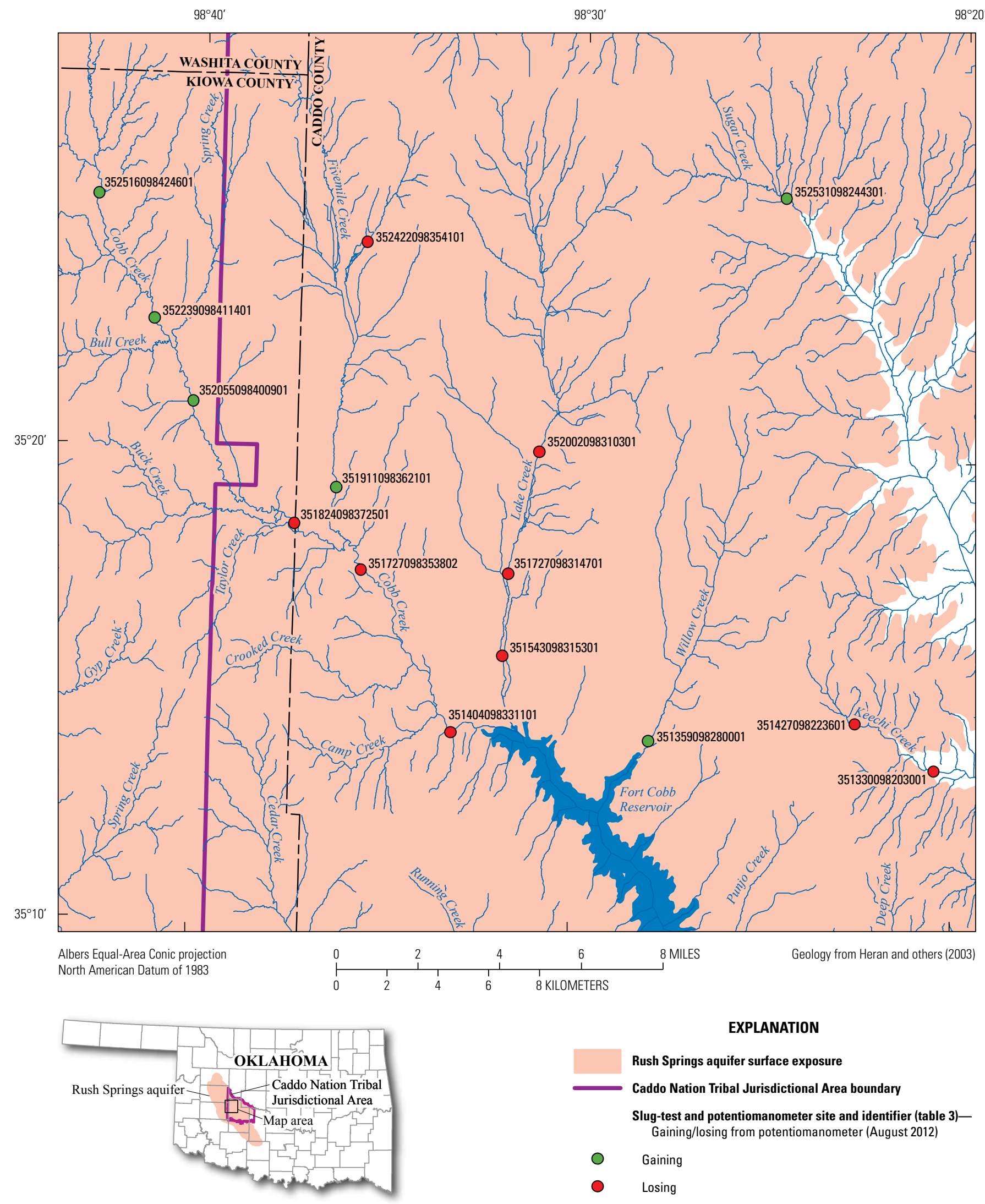

\section{EXPLANATION}

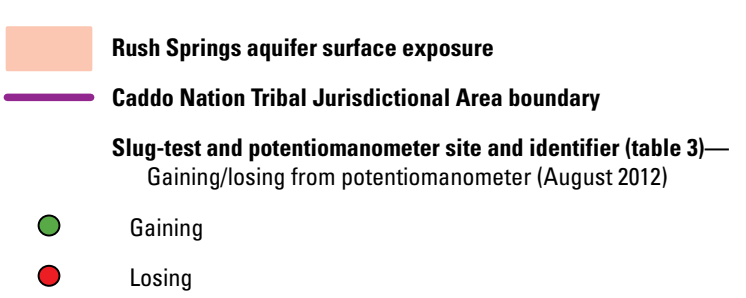

Figure 21. Sites where slug tests and potentiomanometer readings were performed in July 2012 to determine hydraulic conductivity of streambed sediments in Caddo and Washita Counties, Oklahoma. 
Table 2. Completion information for temporary wells installed in the area underlain by the Rush Springs aquifer, southwestern Oklahoma, 2012.

[USGS, U.S. Geological Survey; depths are in feet from land-surface/surface-water interface; WMA, wildlife management area]

\begin{tabular}{|c|c|c|c|c|c|c|}
\hline Agency & $\begin{array}{l}\text { Well identifier } \\
\text { (see fig. 21) }\end{array}$ & Site name & Test date & $\begin{array}{l}\text { Hole } \\
\text { depth }\end{array}$ & $\begin{array}{c}\text { Top screen } \\
\text { depth }\end{array}$ & $\begin{array}{c}\text { Bottom screen } \\
\text { depth }\end{array}$ \\
\hline USGS & 352516098424601 & Cobb Creek at 1100 Road & $8 / 27 / 2012$ & 2.08 & 0.83 & 1.83 \\
\hline USGS & 352239098411401 & Cobb Creek at 1130 Road & $8 / 8 / 2012$ & 1.67 & 0.42 & 1.42 \\
\hline USGS & 352055098400901 & Cobb Creek at 1150 Road near Colony, Okla. & $8 / 27 / 2012$ & 6.50 & 5.25 & 6.25 \\
\hline USGS & 351824098372501 & Cobb Creek at 2450 Road & $8 / 28 / 2012$ & 6.17 & 4.92 & 5.92 \\
\hline USGS & 351727098353802 & Cobb Creek at Highway 152 & $7 / 31 / 2012$ & 15.00 & 13.75 & 14.75 \\
\hline USGS & 352422098354101 & Fivemile Creek at 1110 Road & $8 / 15 / 2012$ & 5.08 & 3.83 & 4.83 \\
\hline USGS & 351911098362101 & Fivemile Creek at 1170 Road & $8 / 2 / 2012$ & 8.67 & 7.42 & 8.42 \\
\hline USGS & 351427098223601 & Keechi Creek at 2590 Road & $8 / 7 / 2012$ & 7.08 & 5.83 & 6.83 \\
\hline USGS & 351330098203001 & Keechi Creek at 2610 Road & $8 / 15 / 2012$ & 5.92 & 4.67 & 5.67 \\
\hline USGS & 352531098244301 & Sugar Creek at 2570 Road & $8 / 14 / 2012$ & 5.92 & 4.67 & 5.67 \\
\hline USGS & 351359098280001 & Willow Creek at 1230 Road & $8 / 14 / 2012$ & 1.67 & 0.42 & 1.42 \\
\hline
\end{tabular}

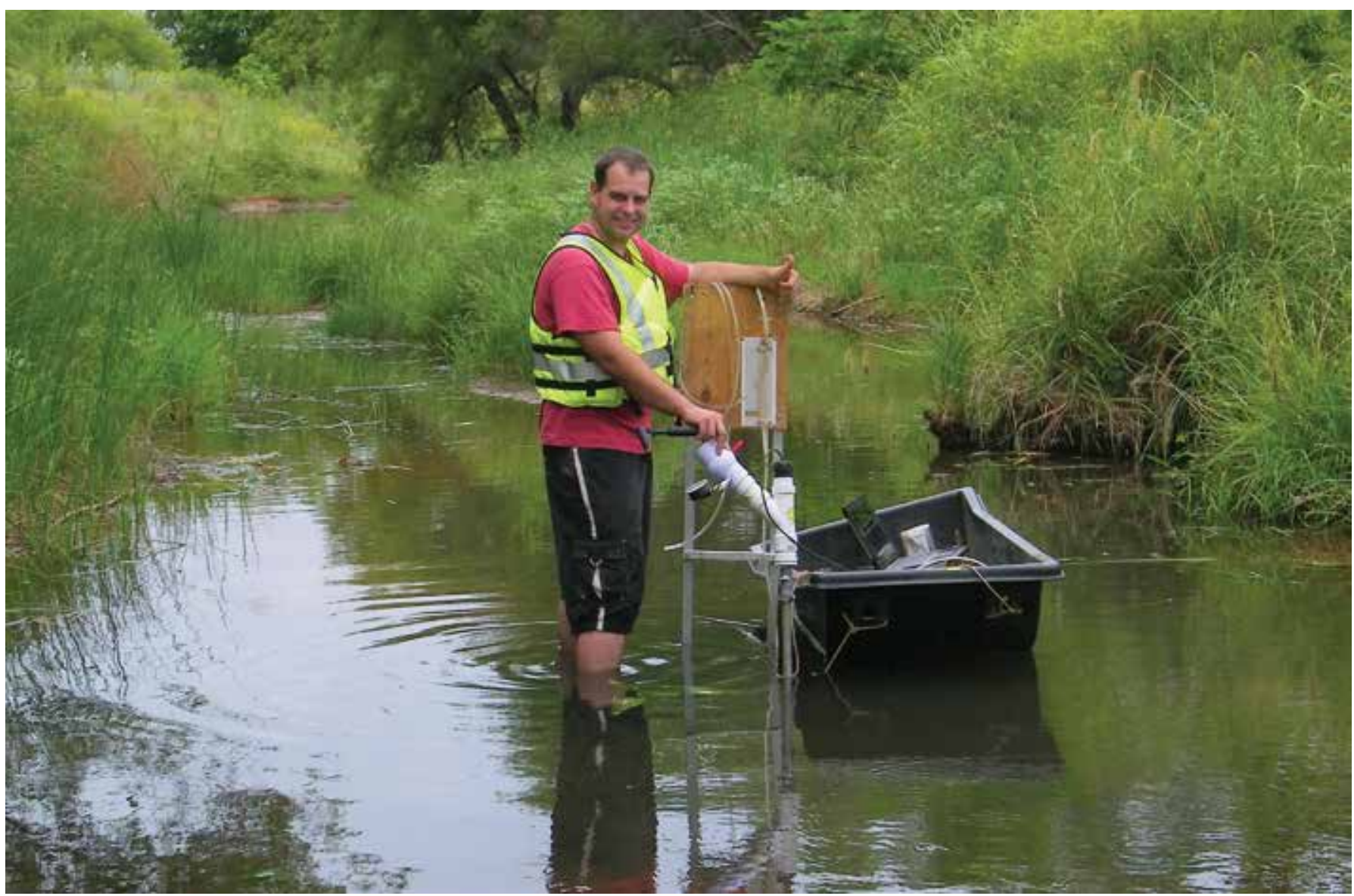

Figure 22. Temporary small-diameter well with pneumatic slug-test equipment installed. 
The KGS Model with Skin solution (Hyder and others, 1994) was developed for an overdamped slug test in an unconfined aquifer for fully and partially penetrating wells. The solution includes a skin zone of finite thickness enveloping the test well. The assumptions for the KGS Model with Skin solution are similar to the assumptions of the Bouwer-Rice solution, but the KGS Model with Skin solution also includes the following assumptions: (1) the aquifer potentiometric surface is initially horizontal, (2) flow is unsteady, and (3) water is released instantaneously from storage with a decline in hydraulic head.

The Bouwer-Rice, Springer-Gelhar, and KGS Model with Skin solutions assume isotropic conditions. For each well site, the presence of anisotropy was anticipated, but the magnitude of the anisotropy was unknown, so the anisotropy in AQTESOLV $(\mathrm{Kv} / \mathrm{Kh}$; $\mathrm{Kv}$ being vertical hydraulic conductivity; Kh being horizontal hydraulic conductivity) was set to 1 and 0.1 to account for the anisotropy typically determined from large-scale pumping tests in the alluvium (Rus and others, 2001). Using $\mathrm{Kv} / \mathrm{Kh}=0.1$ resulted in streambed horizontal hydraulic conductivity values for the well sites that ranged from 1 to 86 feet per day (ft/d), and using $\mathrm{Kv} / \mathrm{Kh}=1$ resulted in streambed horizontal hydraulic conductivity values that ranged from 2 to $53 \mathrm{ft} / \mathrm{d}$ (table 3 ). The hydraulic conductivities derived from these slug tests are typical for fine to coarse sand (Freeze and Cherry, 1979). Converting horizontal hydraulic conductivities from the slug-test analyses to vertical hydraulic conductivities by using a ratio of $\mathrm{Kv} / \mathrm{Kh}=0.1$ indicates that vertical hydraulic conductivity in the streambed sediments overlying the Rush Springs aquifer ranges from $0.1 \mathrm{ft} / \mathrm{d}$ to $8.6 \mathrm{ft} / \mathrm{d}$.

\section{Hydraulic Head in Streams and Alluvium}

A hydraulic potentiomanometer was temporarily installed at the 15 slug-test sites (fig. 21) to determine the hydraulic-head gradient between the stream and alluvium. Comparison of hydraulic head between the stream and alluvium indicates the direction of flow and the magnitude of hydraulic gradients between surface water and groundwater. Hydraulic-head conditions in a stream and alluvium change over time and by location; therefore, the hydraulic data provided are the net directions and magnitude at given places and points in time.

Table 3. Horizontal hydraulic conductivity determined from slug tests conducted in the streambed sediments of streams overlying the Rush Springs aquifer, southwestern Oklahoma, August 2012.

[USGS, U.S. Geological Survey; Kv, vertical hydraulic conductivity; Kh, horizontal hydraulic conductivity; WMA, wildlife management area]

\begin{tabular}{|c|c|c|c|c|c|}
\hline \multirow[t]{2}{*}{ Agency } & \multirow{2}{*}{$\begin{array}{l}\text { Well identifier } \\
\text { (see fig. 21) }\end{array}$} & \multirow[t]{2}{*}{ Site name } & \multirow[t]{2}{*}{ Test date } & \multicolumn{2}{|c|}{$\begin{array}{l}\text { Horizontal hydraulic conductivity } \\
\text { (feet per day) }\end{array}$} \\
\hline & & & & $\mathrm{Kv} / \mathrm{Kh}=0.1$ & $\mathrm{Kv} / \mathrm{Kh}=1$ \\
\hline USGS & 352516098424601 & Cobb Creek at 1100 Road & $8 / 27 / 2012$ & 14 & 8 \\
\hline USGS & 352239098411401 & Cobb Creek at 1130 Road & $8 / 8 / 2012$ & 36 & 22 \\
\hline USGS & 352055098400901 & Cobb Creek at 1150 Road near Colony, Okla. & $8 / 27 / 2012$ & 30 & 18 \\
\hline USGS & 351824098372501 & Cobb Creek at 2450 Road & $8 / 28 / 2012$ & 25 & 15 \\
\hline USGS & 351727098353802 & Cobb Creek at Highway 152 & $7 / 31 / 2012$ & 22 & 13 \\
\hline USGS & 351404098331101 & Cobb Creek at WMA near Lake, Okla. & $8 / 28 / 2012$ & 25 & 15 \\
\hline USGS & 352422098354101 & Fivemile Creek at 1110 Road & $8 / 15 / 2012$ & 40 & 24 \\
\hline USGS & 351911098362101 & Fivemile Creek at 1170 Road & $8 / 2 / 2012$ & 15 & 9 \\
\hline USGS & 351427098223601 & Keechi Creek at 2590 Road & $8 / 7 / 2012$ & 16 & 10 \\
\hline USGS & 351330098203001 & Keechi Creek at 2610 Road & $8 / 15 / 2012$ & 13 & 8 \\
\hline USGS & 352002098310301 & Lake Creek at 1160 Road & $8 / 29 / 2012$ & 86 & 53 \\
\hline USGS & 351543098315301 & Lake Creek at 1210 Road & $8 / 29 / 2012$ & 26 & 16 \\
\hline USGS & 351727098314701 & Lake Creek at Highway 152 & $8 / 2 / 2012$ & 33 & 20 \\
\hline USGS & 352531098244301 & Sugar Creek at 2570 Road & $8 / 14 / 2012$ & 40 & 25 \\
\hline USGS & 351359098280001 & Willow Creek at 1230 Road & $8 / 14 / 2012$ & 1 & 2 \\
\hline
\end{tabular}


A hydraulic potentiomanometer, or minipiezometer, is a portable drive probe connected to a manometer (fig. 23). The temporary wells used for the slug tests ("Streambed Hydraulic Conductivity" section of this report) were also used for the potentiomanometer readings in July and August 2012. The slotted drive probe was pushed down inside the casing of the temporary well after the slug test was performed, while the outer tube was placed at the bottom of the stream next to the well. Water was pumped with a peristaltic pump up through the well screen and tubing. Once the tubing was full of water and free of bubbles, air was bled into the top of the manometer until the menisci were visible in the tubing on both sides of the manometer. Hydraulic head was recorded for the stream and the alluvium. Differences in hydraulic head between a stream and alluvium can indicate gaining and losing stream reaches. Gaining-stream reaches gain water from inflow of groundwater through the streambed. Losing-stream reaches lose water to groundwater by outflow from the stream through the streambed.

At 6 of the 15 sites, direction of flow was from the alluvium to the stream (gaining) and the magnitude of the hydraulic-head gradient ranged from 0.003 to 0.323 . For the nine sites with direction of flow from the stream to the alluvium (losing), hydraulic head gradients ranged from 0.004 to 0.076 (table 4).

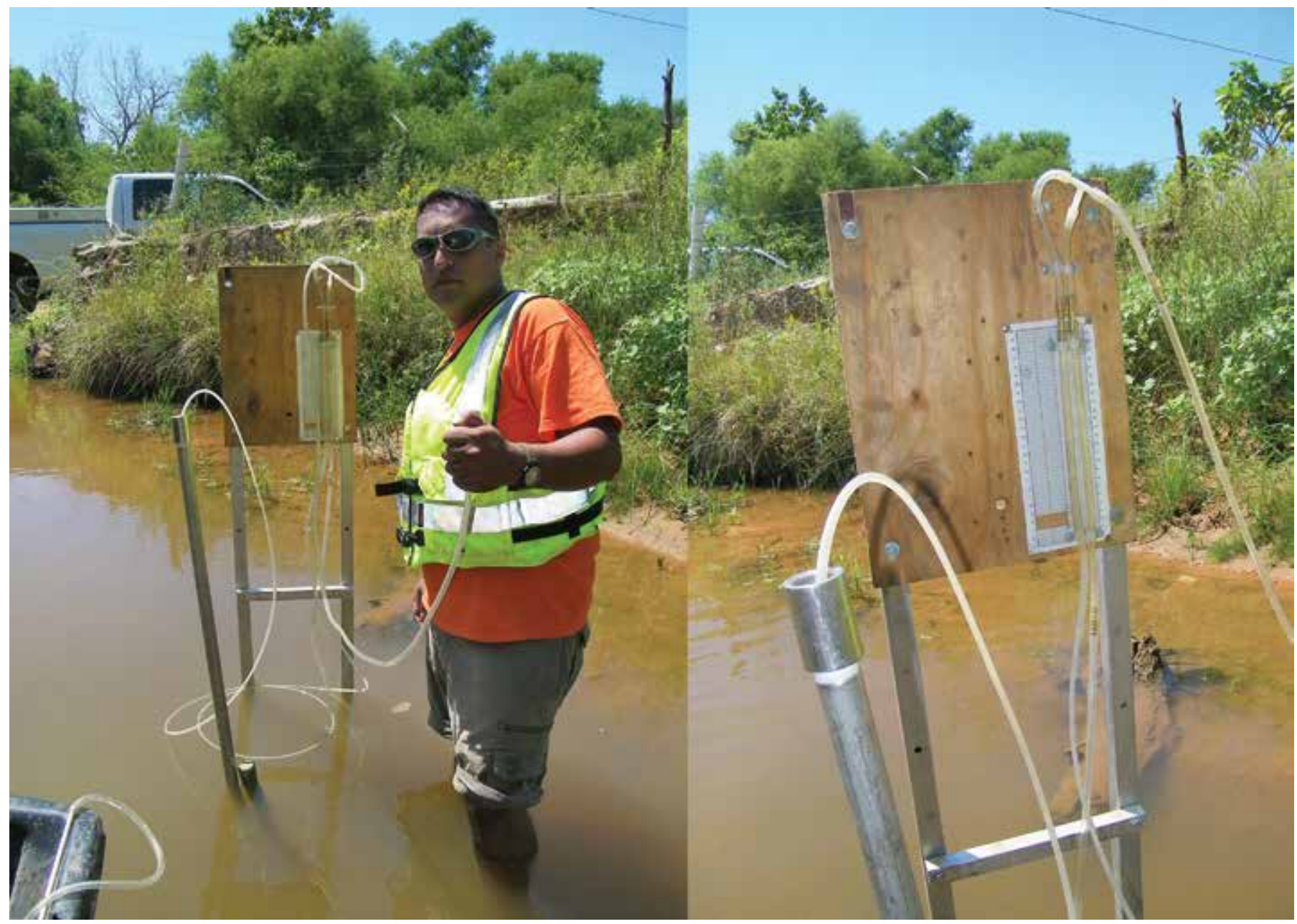

Figure 23. Potentiomanometer and temporary small-diameter well, with the manometer mounted on a wooden board. 
Table 4. Hydraulic head differences and gradients between streams and alluvium determined from potentiomanometer readings, in areas underlain by the Rush Springs aquifer, southwestern Oklahoma, August 2012.

[USGS, U.S. Geological Survey; WMA, wildlife management area; Negative values indicate flow from stream to alluvium sediments while positive values indicate flow from alluvium sediments to stream]

\begin{tabular}{lllccc}
\hline Agency & Well identifier & \multicolumn{1}{c}{ Site name } & $\begin{array}{c}\text { Difference in head } \\
\text { (inches) }\end{array}$ & $\begin{array}{c}\text { Vertical hydraulic } \\
\text { head gradient }\end{array}$ & $\begin{array}{c}\text { Gaining/ } \\
\text { losing' }\end{array}$ \\
\hline USGS & 352516098424601 & Cobb Creek at 1100 Road & 2.480 & 0.155 & Gaining \\
USGS & 352239098411401 & Cobb Creek at 1130 Road & 3.563 & 0.323 & Gaining \\
USGS & 352055098400901 & Cobb Creek at 1150 Road near Colony, Okla. & 0.184 & 0.003 & Gaining \\
USGS & 351824098372501 & Cobb Creek at 2450 Road & -0.246 & -0.004 & Losing \\
USGS & 351727098353802 & Cobb Creek at Highway 152 & -3.150 & -0.018 & Losing \\
USGS & 351404098331101 & Cobb Creek at WMA near Lake, Okla. & -3.858 & -0.076 & Losing \\
USGS & 352422098354101 & Fivemile Creek at 1110 Road & -1.594 & -0.031 & Losing \\
USGS & 351911098362101 & Fivemile Creek at 1170 Road & 15.183 & 0.160 & Gaining \\
USGS & 351427098223601 & Keechi Creek at 2590 Road & -5.285 & -0.070 & Losing \\
USGS & 351330098203001 & Keechi Creek at 2610 Road & -1.339 & -0.022 & Losing \\
USGS & 352002098310301 & Lake Creek at 1160 Road & -0.079 & -0.004 & Losing \\
USGS & 351543098315301 & Lake Creek at 1210 Road & -1.247 & -0.032 & Losing \\
USGS & 351727098314701 & Lake Creek at Highway 152 & -0.394 & -0.009 & Losing \\
USGS & 352531098244301 & Sugar Creek at 2570 Road & 2.943 & 0.047 & Gaining \\
USGS & 351359098280001 & Willow Creek at 1230 Road & 1.417 & 0.128 & Gaining \\
\hline
\end{tabular}

${ }^{1}$ Gaining stream reaches gain water from inflow of groundwater through the streambed. Losing stream reaches lose water to groundwater by outflow through the streambed.

Hydraulic-head differences in three of the six sites on Cobb Creek indicate that flow direction was from groundwater to surface water (gaining-stream section) (fig. 21 and table 4). These three sites are in the western part of the aquifer in Kiowa County. Hydraulic-head differences in the other three sites on Cobb Creek in western Caddo County indicate that flow direction was from surface water to groundwater (losing-stream section). Hydraulic-head differences at Fivemile Creek at 1110 Road indicate that flow direction was from surface water to groundwater (losing-stream section), whereas hydraulic-head differences at Fivemile Creek at 1170 Road indicate flow was from groundwater to surface water (gaining-stream section) with a relatively high vertical hydraulic gradient. Hydraulic-head differences at the two sites on Keechi Creek indicate that flow was from surface water to groundwater (losing-stream section). Hydraulichead differences at the three sites on Lake Creek indicate that flow was from surface water to groundwater (losing-stream section). Hydraulic-head differences on the Sugar Creek and Willow Creek sites indicate that flow was from groundwater to surface water (gaining-stream section). Gaining and losing conditions along streams can change in time and by location. There are several factors that could cause a stream to be gaining or losing or cause changes in flow direction. A stream will be gaining if the head in the aquifer is higher than the head in the stream and a stream will be losing if the head in the aquifer is lower than the head in the stream. Groundwater use that causes the aquifer head to decline lower than the head in the stream will cause the stream to be losing. Most of the measured streams were losing, as they were measured in July and August, during times of the year that declines in water levels are observed across the Rush Springs aquifer (see the "Groundwater Level Fluctuations, 2010-13" section of this report).

\section{Volumetric Flow Rates from Seepage Meters}

Flux of water across the stream/alluvium interface was measured at five locations by using seepage meters during July through August 2012. Seepage-meter methods are described in Rosenberry and LaBaugh (2008). Locations where seepage meters were installed were: (1) Cobb Creek at 1150 Road, (2) Cobb Creek at Highway 152 (Oklahoma State Highway 152), (3) Fivemile Creek at 1170 Road, (4) Lake Creek at 1160 Road, and (5) Willow Creek at 1230 Road (fig. 21 and table 5). Seepage meters typically are constructed from a cutoff storage drum that is installed into streambed sediments. A collector bag is attached to the drum, and the change in the volume of the water in the bag over time is measured. A decrease in volume of water in the bag over time indicates flux from surface water to groundwater. An increase in the volume of water in the bag over time indicates flux from groundwater to surface water. Volumetric flow rates and flux velocities vary by location and with time. 
Table 5. Seepage locations and flux velocities for sites measured in the area underlain by the Rush Springs aquifer, southwestern Oklahoma, July-August 2012.

[USGS, U.S. Geological Survey; Negative values indicate flow from stream to alluvium sediments while positive values indicate flow from alluvium sediments to stream]

\begin{tabular}{|c|c|c|c|c|c|c|c|}
\hline \multirow[t]{2}{*}{ Agency } & \multirow{2}{*}{$\begin{array}{c}\text { Well } \\
\text { identifier }\end{array}$} & \multirow[t]{2}{*}{ Site name } & \multirow{2}{*}{$\begin{array}{c}\text { Date } \\
\text { measured }\end{array}$} & \multicolumn{4}{|c|}{$\begin{array}{l}\text { Flux velocity } \\
\text { (feet per day) }\end{array}$} \\
\hline & & & & Site A & Site B & Site C & Site D \\
\hline USGS & 352055098400901 & Cobb Creek at 1150 Road near Colony, Okla. & $7 / 8 / 2012$ & 0.039 & 0.019 & 0.013 & -0.002 \\
\hline USGS & 351727098353802 & Cobb Creek at Highway 152 & $7 / 21 / 2012$ & -0.140 & -0.016 & -0.003 & -0.113 \\
\hline USGS & 351911098362101 & Fivemile Creek at 1170 Road & $8 / 2 / 2012$ & -0.131 & -0.045 & 0.017 & 0.039 \\
\hline USGS & 352002098310301 & Lake Creek at 1160 Road & $7 / 31 / 2012$ & 0.023 & 0.005 & 0.014 & 0.018 \\
\hline USGS & 351359098280001 & Willow Creek at 1230 Road & $8 / 7 / 2012$ & -0.066 & -0.077 & -0.127 & -0.107 \\
\hline
\end{tabular}

The seepage meters used for this study were constructed of a 55-gallon storage drum from which the end was cut off. The storage drum had a diameter of 22 inches and an area of 2.64 square feet. A collector bag and tubing with a 3/4inch inside diameter was attached to the top of the storage drum by a $1 / 2$-inch inside-diameter connector. Fellows and Brezonik (1980) suggested that a tubing diameter larger than a 5-millimeter ( 0.20 -inch) opening would not cause loss of efficiency for most fluxes commonly measured with seepage meters. The seepage meters were pushed into the streambed sediments with the collector bag filled with an initial volume of 2,000 milliliters of water. The seepage meters were left installed in the sediments for 1 to 3 hours. The end volume of water was measured from the collector bag and the time logged for each measurement interval.

At each of the five locations where seepage meters were installed, four different seepage meters were placed at various sites in the streambed sediments within about $100 \mathrm{ft}$ of the wells (fig. 21). Measurements at four different sites were made to account for the spatial variability of fluxes across the stream/alluvium interface. Water-volume measurements were logged over two time intervals to ensure that measurements were repeatable and similar at each site.

Change in volume of water in the collector bag was divided by the area of the storage drum to normalize and determine a flux velocity (table 5 ). This flux velocity represents the measured flow rate across the stream/alluvium interface. Measurements at sites A, B, and C at Cobb Creek at 1150 Road near Colony, Okla., indicate that flow from the alluvium to the stream ranged from 0.013 to $0.039 \mathrm{ft} / \mathrm{d}$, whereas measurements at site D indicated flow from the stream to alluvium (table 5). Measurements at all four sites at Cobb Creek at Highway 152 (Oklahoma State Highway 152) indicated that flow from the stream to the alluvium ranged from 0.003 to $0.140 \mathrm{ft} / \mathrm{d}$ (table 5). Measurements at sites A and $\mathrm{B}$ at the Fivemile Creek at 1170 Road location indicated flow from the stream to alluvium, with flux velocity of 0.045 and
$0.131 \mathrm{ft} / \mathrm{d}$, whereas measurements at sites $\mathrm{C}$ and $\mathrm{D}$ indicated flow from the alluvium to the stream with flux velocity from 0.017 to $0.039 \mathrm{ft} / \mathrm{d}$. Measurements at all four sites at the Lake Creek at 1160 Road location indicated that flow from the alluvium to the stream ranged from 0.005 to $0.023 \mathrm{ft} / \mathrm{d}$. Measurements at all four sites at the Willow Creek at 1230 Road location indicated that flow from the stream to the alluvium ranged from 0.066 to $0.127 \mathrm{ft} / \mathrm{d}$.

Flows determined from seepage meters, combined with hydraulic gradients determined from potentiomanometers, were used to determine the vertical hydraulic conductivity of the streambed sediments using Darcy's law (Darcy, 1856). Darcy's law is expressed as:

$$
Q=K I A
$$

where

$$
\begin{aligned}
Q & \text { is flow, in cubic feet per day; } \\
K & \text { is hydraulic conductivity, in feet per day; } \\
I & \text { is the hydraulic head gradient; and } \\
A & \text { is the cross-sectional area, in square feet. }
\end{aligned}
$$

For sites where seepage meters were deployed, the flux velocity from table 5 (equivalent to $\mathrm{Q} / \mathrm{A}$ from equation 1 ) was divided by the vertical hydraulic head gradient from table 4 to determine the vertical hydraulic conductivity of the streambed sediments. The vertical hydraulic conductivity $(\mathrm{Kv})$ using Darcy's law ranged from 0.1 to $13 \mathrm{ft} / \mathrm{d}$ for all sites. The $\mathrm{Kv}$ at Cobb Creek at 1150 Road near Colony, Okla., site ranged from 0.7 to $13 \mathrm{ft} / \mathrm{d}$. The $\mathrm{Kv}$ at Cobb Creek at Highway 152 site ranged from 0.2 to $7.8 \mathrm{ft} / \mathrm{d}$. The Kv at Fivemile Creek at 1170 Road ranged from 0.1 to $0.8 \mathrm{ft} / \mathrm{d}$. The Kv at Lake Creek at 1160 Road ranged from 1.3 to $5.8 \mathrm{ft} / \mathrm{d}$. The $\mathrm{Kv}$ at Willow Creek at 1230 Road ranged from 0.5 to $1 \mathrm{ft} / \mathrm{d}$. The vertical hydraulic conductivities determined using Darcy's law were similar to the streambed hydraulic conductivities estimated from the slug tests, using a ratio of $\mathrm{Kv} / \mathrm{Kh}=0.1$, that ranged from $0.1 \mathrm{ft} / \mathrm{d}$ to $8.6 \mathrm{ft} / \mathrm{d}$. 
Interaction between Groundwater and Surface Water at Cobb Creek near the Eakly, Oklahoma, Streamflow-Gaging Station

In April 2011, USGS staff conducted site reconnaissance and installed water-table piezometers in the Cobb Creek alluvium adjacent to the Cobb Creek near Eakly, Okla. (USGS station number 07325800) streamflow-gaging station, by using mechanical direct-push methods. The purpose of piezometer installation was to monitor and record interactions between alluvial groundwater levels and stream stage from September 2011 through August 2012. Hydraulic connection between the alluvial aquifer and the Rush Springs aquifer was assumed because the Rush Springs aquifer consists of well-sorted, poorly cemented sandstone in the study area, and the alluvial aquifer consists of unconsolidated sands, silts, and clays with some gravel.

Piezometers were installed at various distances from the stream channel near the streamflow-gaging station orifice (fig. 24). The piezometers were constructed with 1-inch diameter polyvinyl chloride casing and 5-ft-long prepack screens set just above the contact with the Rush Springs aquifer, which was at about $20-45 \mathrm{ft}$ below the land surface (fig. 25). Water levels were initially recorded with an electric tape at about $10-20 \mathrm{ft}$ below the land surface at the time of piezometer-well installation (U.S. Geological Survey, 2013; fig. 25A). Each piezometer was then developed for about half an hour with a peristaltic pump until the produced water appeared to be clear of sediment. On September 22, 2011, four of the piezometers (well 0 [351726098353801], well 2 [351726098353701], well 3 [351726098353601], and well 5 [351726098353501]) were equipped with Level TROLL 500 unvented pressure transducers with internal data loggers recording hydraulic pressure measurements every 15 minutes. The four transducer-equipped piezometers were spaced about $10,115,170$, and $260 \mathrm{ft}$, respectively, from the center of Cobb Creek and formed a transect through the alluvium. A recording barometer (Baro TROLL 500) also was deployed at the site to correct the pressure-transducer data to atmospheric pressure (Freeman and others, 2004). On November 8, 2011, the well nearest Cobb Creek (well 0 [351726098353801]) was damaged by a flood with a crest stage of $1,386.16$ $\mathrm{ft}$ National Geodetic Vertical Datum (NGVD 29) and a maximum instantaneous discharge of $2,140 \mathrm{ft}^{3} / \mathrm{s}$ (station number 07325800; U.S. Geological Survey, 2013; fig. 26). Because well 0 was damaged from the flood, well 0 data are not included in this report. All other piezometer water levels were corrected for atmospheric pressure and referenced to the datum of the streamflow-gaging station number 07325800 , which is NGVD 29.

The piezometer transect is parallel to the Oklahoma State Highway 152 bridge, just south of the eastern bridge abutment (fig. 24). Along the piezometer transect, the land slopes toward the river at about $1 \mathrm{ft}$ per $30 \mathrm{ft}$ between wells 5 and 2 and at about $1 \mathrm{ft}$ per $7 \mathrm{ft}$ between wells 2 and 0 . A drainage ditch also runs parallel to Oklahoma State Highway 152 on the south side of the piezometer transect. Near well 3, the drainage ditch opened to a deep (5-10 ft) gulley and turned southwest to Cobb Creek. This gulley may have acted as a drain on the alluvial aquifer. The land surrounding the Cobb Creek site was used mostly for nonirrigated and irrigated agriculture. Several irrigation wells were located in the area, including one on the west side of Cobb Creek about $270 \mathrm{ft}$ southwest of well 2 in the piezometer transect.

Because of the relatively high slope of the land surface, most streams overlying the Rush Springs aquifer convey flashy discharges after intense rainfall. Cobb Creek, for example, often returns to prestorm stage within a few days of an intense rainfall. Following the June 7-11, 2012, rainfall, stream stage was higher than water levels in wells 2 and 3 (fig. 26). In mid-July 2012, following a few more rain events, stream stage was higher than at all three wells. The stream was losing for a few weeks in June and July because of a combination of runoff, which raised the stream stage, and possibly well pumping, which likely lowered groundwater levels. Recharge from surface-water runoff and flood flows, therefore, were not likely to have a large effect on alluvial and bedrock groundwater levels at this Cobb Creek near Eakly, Okla., location over the course of a year. 


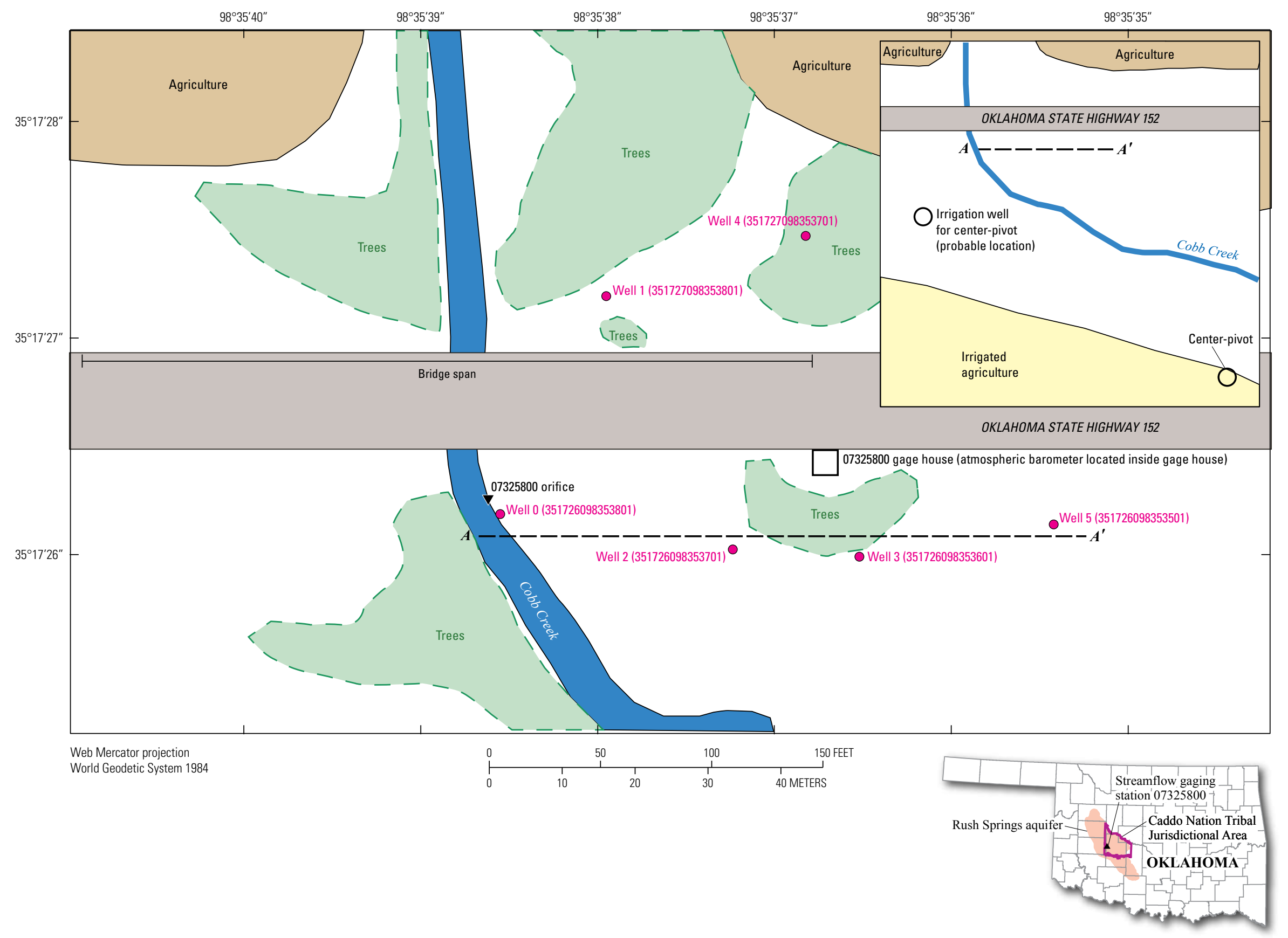

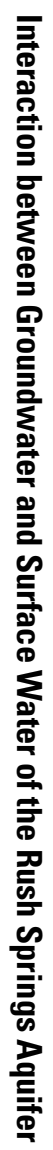

Figure 24. Diagram showing groundwater and surface-water data-collection stations at Cobb Creek near Eakly, Oklahoma, on Oklahoma State Highway 152. 


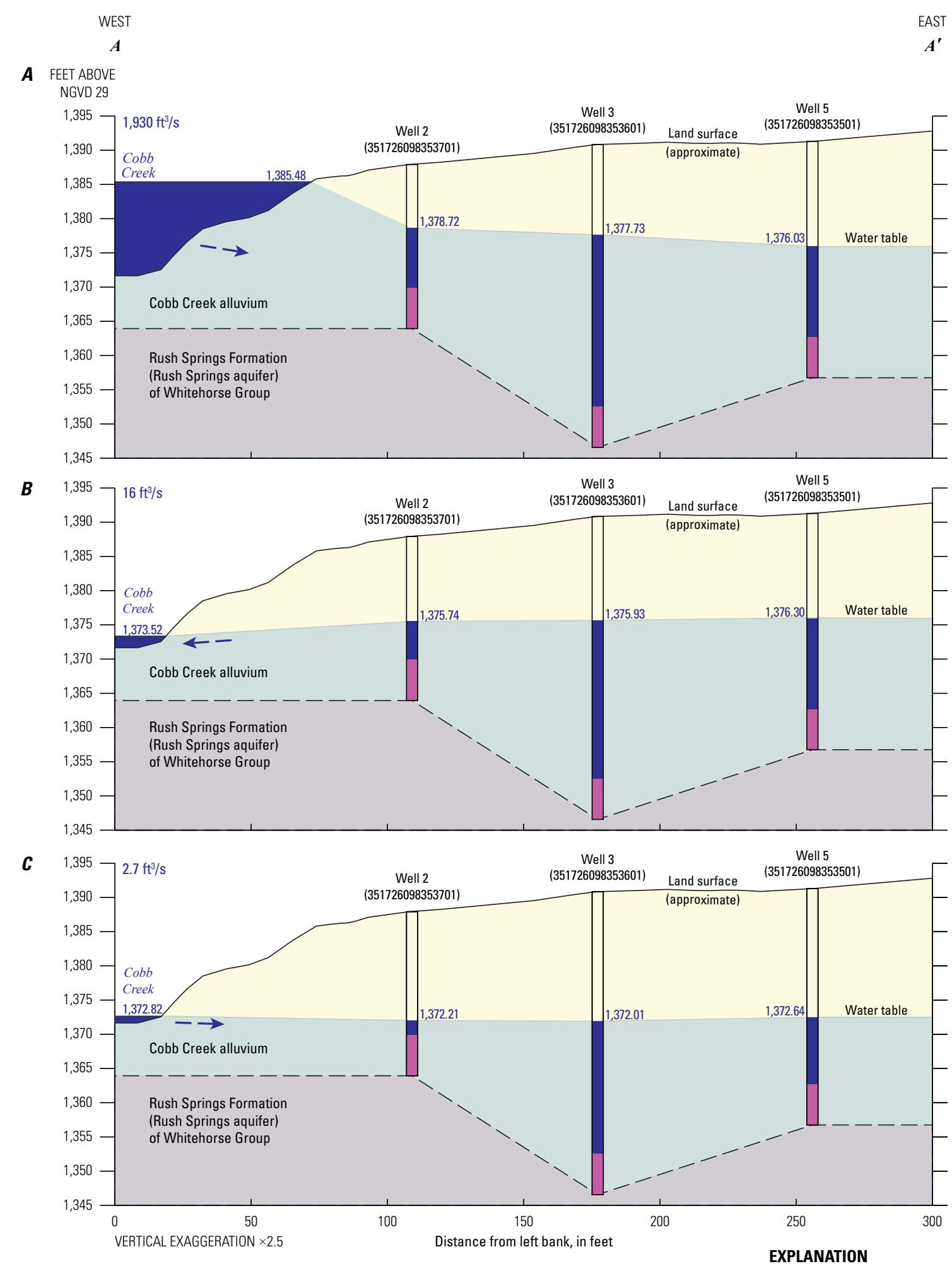

1,372.82 Observed water-table altitude, in feet

$2.7 \mathrm{ft}^{3} / \mathrm{s}$ Instantaneous discharge at Cobb Creek near Eakly (07325800) in cubic feet per second $\left(\mathrm{ft}^{3} / \mathrm{s}\right)$

Screened interval

$\leftarrow--$ Direction of groundwater flow

Figure 25. Schematic diagram showing cross sections of a piezometer transect in the Cobb Creek alluvium showing altitudes of Cobb Creek and the alluvial aquifer water table during $(A)$ flooding-stream conditions on November 8, 2011, 2:30 a.m.; $(B)$ normal, gainingstream conditions on March 1, 2012, 8:30 a.m.; and (C) losing-stream conditions on July 29, 2012, 8:30 a.m. 


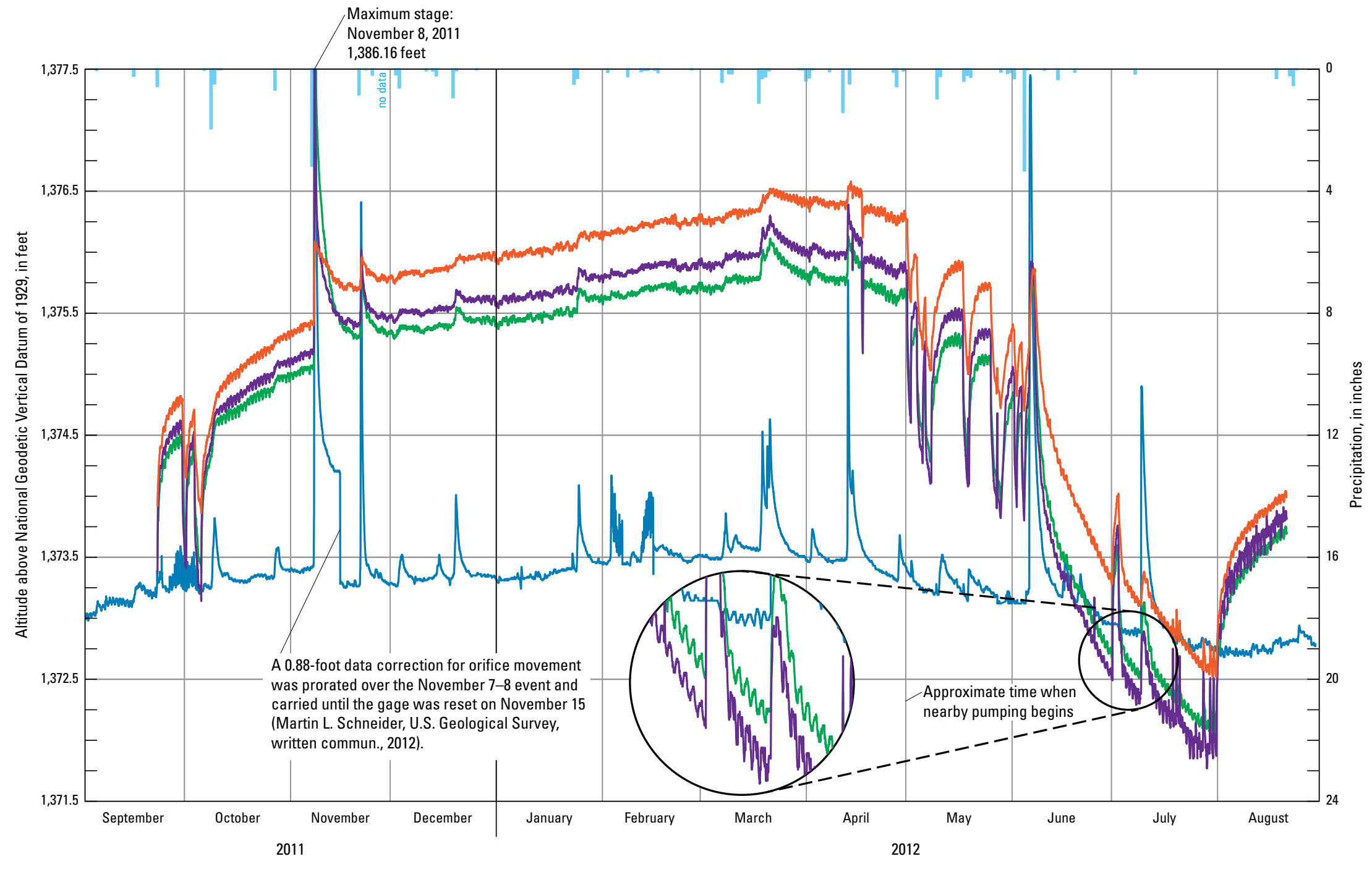

EXPLANATION

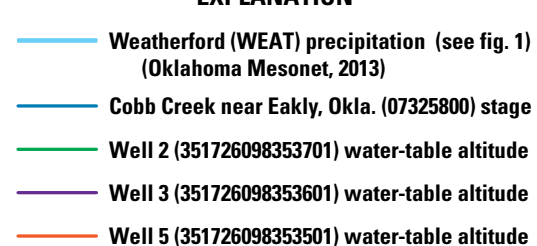

Figure 26. Water-table altitudes measured at U.S. Geological Survey streamflow-gaging station 07325800 (Cobb Creek near Eakly, 0klahoma) and in three piezometers in the Cobb Creek alluvium showing altitudes of Cobb Creek and the alluvial groundwater table and precipitation measured at Weatherford, Okla., Mesonet station (see fig. 1 for location), September 2011-August 2012. 
The stream-stage and groundwater-level data collected at the Cobb Creek site indicate how surface water and groundwater interact at the site during a drought year. From September 2011 to mid-June 2012 and in the month of August 2012, groundwater levels at wells 2,3, and 5 were higher than the stream stage, indicating that this reach of Cobb Creek was a gaining stream for most of the study period (fig. 26). The 6-month upward trend in stream stage and groundwater levels reversed in mid-March. Evapotranspiration signatures (serrated pattern with 1-day frequency; see inset of fig. 26) also began appearing in mid-March and increased in amplitude as solar radiation and native vegetation activity increased into the summer. The altitude difference between groundwater levels and stream stage increased over the fall and spring months and reached a maximum of about 2.5-3.0 ft in March and April (fig. 26). The altitude of groundwater levels and stream stage began to decrease in late March. In May and early June, groundwater pumping and recovery signatures from a nearby irrigation-supply well about $270 \mathrm{ft}$ southwest of the piezometer transect were evident in the aquifer waterlevel and stream-stage data (fig. 26). Well-completion reports indicated that the irrigation well was completed in the Rush Springs aquifer at a depth of about $260 \mathrm{ft}$ below land surface in 2009 and produced an estimated yield of 200$400 \mathrm{gal} / \mathrm{min}$ (Oklahoma Water Resources Board, 2013). In the remainder of June and July, groundwater levels and stream stage decreased, and the direction of the groundwater gradient between wells 2 and 3 changed. With the combined effects of evapotranspiration and pumping that decreased groundwater levels and periodic rainfall runoff that raised the stream stage, this reach of Cobb Creek became a losing stream in mid-June and July, with stream-stage altitudes greater than aquifer water-level altitudes in wells 2 and 3 (figs. $25 C$ and 26). The lack of pumping recovery curves between mid-June and July indicates that groundwater-level and stream-stage declines were most likely the result of regional-scale withdrawals of multiple wells instead of the result of a single nearby pumping well. In August 2012, groundwater levels and stream stage began to increase, presumably when irrigation ceased at the end of the winter wheat and corn growing seasons. Winter wheat is harvested during June to early July and corn is harvested during August to October (Oklahoma Department of Agriculture, Food and Forestry, 2012). Also, the stream reach returned to a gaining stream and the groundwater gradient reversed, with aquifer water-level altitudes greater than the stream-stage altitude (fig. 26).

The groundwater and surface-water interaction data collected at streamflow-gaging station 07325800 (Cobb Creek near Eakly, Okla.) indicate that the bedrock groundwater, alluvial groundwater, and streams were in hydrologic connection in the study area. Because of this hydrologic connection, large perennial streams in the study area can change from gaining to losing streams in the summer. The timing and severity of this change probably were affected by regional withdrawal of groundwater for irrigation during the summer growing season. Pumping wells placed closer to streams are likely to have a greater and more immediate effect on alluvial groundwater levels and stream stages than wells placed farther from streams. Large-capacity irrigation wells, even those completed hundreds of feet below land surface in the bedrock aquifer, can induce surface-water flow from nearby streams by lowering alluvial groundwater levels below the stream altitude.

\section{Springs Inventory and Location of Wetlands}

Documentation of springs and wetlands is important because these features mark the intersection of the groundwater table with the surface water and are therefore indicators of change in a hydrologic system. When groundwater levels fall as a result of less than normal precipitation, such as during 2011 (fig. 2), springs may stop discharging water, and wetland areas may become dry. Spring and wetland inventories were the focus of a 2011-12 field survey of the Caddo Nation Tribal Jurisdictional Area, and precipitation had been less than normal in 2011 (fig. 2). Funding and time constraints precluded a comprehensive search of the area, so the goals of the spring and wetland inventories were (1) to compile historical documentation on spring and wetland locations, and (2) to identify new, undocumented spring and wetland locations accessible from public roads. The results from this inventory could provide data for a more comprehensive search for these features in the future.

Prior to 2012, only two springs were documented in the NWIS database (U.S. Geological Survey, 2013) in the study area, but neither location was sufficiently accurate to locate the springs in the field during the summer of 2012. Because there were no useful historical spring locations in the study area, the primary objective of this study was to locate and document springs. Twenty-five springs visible from public roads and paths were documented during the survey (fig. 27). Two of these springs were in Red Rock Canyon State Park. 


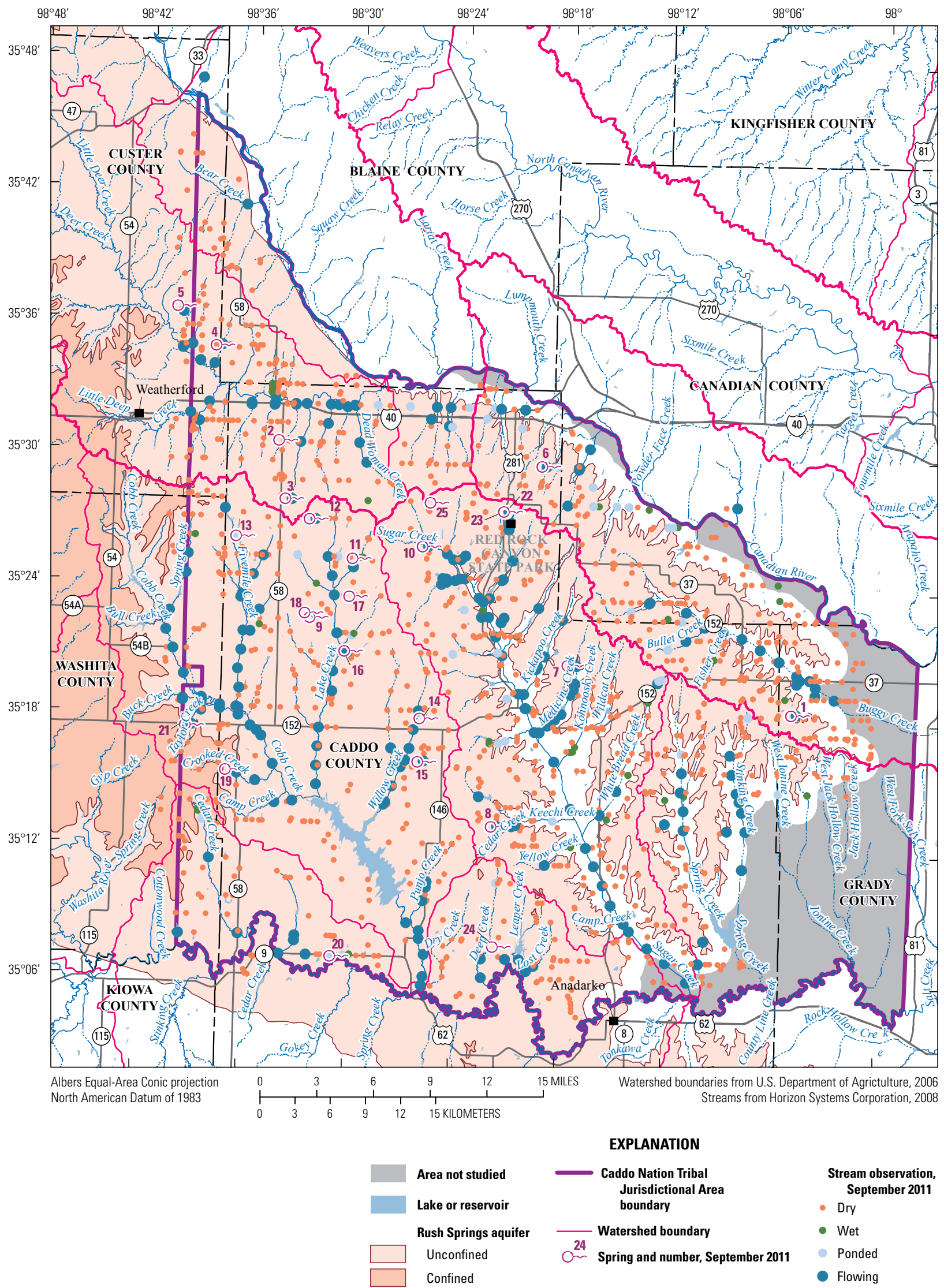

Figure 27. Locations of springs and stream observations in and near the Caddo Nation Tribal Jurisdictional Area, Oklahoma, September 2011. 
All of the documented springs were discharging water at very low rates during the time they were identified. Spring discharge in the study area seems to be primarily in the form of distributed seep areas rather than discrete openings in rocks. Many of the springs documented in this report, such as the two springs in Red Rock Canyon State Park (fig. 27), were found in plunge pools where the sandstone has been eroded by runoff from upstream roads, culverts, dams, and rock outcrops in the study area. Most of the springs documented in this report are located in upland draws on the flanks of a topographic ridge that trends southeast from Weatherford to Anadarko (fig. 27). This ridge is believed to coincide with a groundwater divide separating groundwater flow between the Sugar Creek and Cobb Creek surface-water drainage systems. Of the 25 springs recorded in the study area, 6 were on tributaries of Sugar Creek, 11 were on tributaries of Cobb Creek, and 8 were on tributaries of the Canadian and Washita Rivers. All springs were flowing at the time of the field survey, but none of the springs were discharging enough water to obtain accurate discharge measurements. All of the documented springs were estimated to be discharging less than $1 \mathrm{ft}^{3} / \mathrm{s}$.

One of the challenges with spring identification in the study area is that much of the study area is occupied by deep draws and canyons that were not accessible during the field survey. Privately owned areas with rugged terrain and no improved vehicular access were not surveyed but may contain springs and seeps. Also, many of the spring-discharge areas have been inundated by small ponds impounded by dams on private land. Many small headwater ponds were at design capacity and were discharging water during the field survey, indicating that the ponds were supplied by spring flow.

More generalized spring-discharge areas were identified by documenting stream conditions in the study area. As a result of less than normal precipitation in western Oklahoma (fig. 2), many of the streams in the study area were dry in the summer and fall of 2011. All streamflow was considered to be groundwater-supplied base flow (supplied by springs and seeps) at the time of the spring inventory. For 2 weeks in September, a field crew visited 1,665 county and State road bridges over streams in the Caddo Nation Tribal Jurisdictional Area, qualitatively documenting streamflow conditions. For each bridge location, the stream was classified into one of four categories: (1) dry (the streambed was dry), (2) wet (the streambed was wet, but there was no standing or flowing water), (3) ponded (the stream contained standing water that was not observed as flowing; dammed streams with no observable outflow were included in this category), and (4) flowing (the stream contained moving water; dammed streams with observable outflow were included in this category). Each of the stream observations was input into a geographic information system (GIS) database (fig. 27). Though this sample of stream observations is biased toward smaller streams, which are more easily crossed and thus have more bridges, these data could be used to map perennial streams or to delineate areas for more focused spring inventories. Nearly the entire lengths of Cobb Creek, Sugar Creek, Cedar Creek, Deer Creek, Lake Creek, Willow
Creek, Fivemile Creek, and Buggy Creek were observed to be flowing in the study area in September 2011 and were thus considered to be perennial. Many of the smaller tributaries to these streams also were flowing in September 2011. The Washita River was observed to be flowing in the study area in September 2011, but the Canadian River was dry. The year 2011 was particularly dry (fig. 2), and stream reaches that were flowing in September 2011 when there had been little rainfall were probably perennial.

The distribution of flowing-stream observations was compared with National Hydrography Dataset (NHDPlusV1) (Horizon Systems Corporation, 2008) perennial stream designations. This comparison was used as an independent check of perennial streams for quality assurance. The stream observations generally corresponded to the NHDPlusV1 perennial streams, but there were some notable differences. Buggy Creek, Spring Creek, and Stinking Creek, which drained the aquifer near the Marlow Formation contact on the eastern side of the study area, were not listed as perennial for most of their length in NHDPlusV1 but were observed to be flowing along most of their length in September 2011. Also, the Canadian River is listed as perennial for most of its length in NHDPlusV1 but was dry in September 2011. In the western part of the study area, a few small streams were listed as perennial in NHDPlusV1 but were not flowing in September 2011.

Wetlands primarily were identified by using a combination of data sources including the National Wetlands Inventory (NWI) (U.S. Fish and Wildlife Service, 2013), Soil Survey Geographic database (SSURGO) frequently flooded soils maps (U.S. Department of Agriculture Natural Resources Conservation Service, 2013), and aerial photographs (U.S. Department of Agriculture Farm Service Agency, 2013) (fig. 28). Two wetland classes are common in the study area $\left(1,153.73 \mathrm{mi}^{2}\right)$ : (1) freshwater emergent wetlands, which comprise $3.34 \mathrm{mi}^{2}$ (0.29 percent) and (2) freshwater forested/ shrub wetlands, which comprise $13.37 \mathrm{mi}^{2}$ (1.16 percent) (U.S. Fish and Wildlife Service, 2013). The emergent wetland class is characterized by erect, rooted, herbaceous hydrophyte plants, which are present for most of the growing season in most years. The freshwater forested/shrub wetland class includes areas dominated by woody vegetation including shrubs and trees taller than $20 \mathrm{ft}$. According to the SSURGO data, the Gracemont soil group of Caddo and Blaine Counties is the primary frequently flooded soil in the study area (U.S. Department of Agriculture Natural Resources Conservation Service, 2013). These soil groups are located along major streams, including the Canadian River, Fivemile Creek, Lake Creek, Spring Creek tributaries, and Sugar Creek tributaries (see fig. 27 for stream locations). During the field survey, a few wetland areas were observed that were not documented in the NWI or SSURGO. Most of these sites were just upstream and downstream from ponds in narrow canyons and draws. Site access and detailed vegetation surveys would be needed, however, for confirmation and documentation of these possible additional wetlands. 


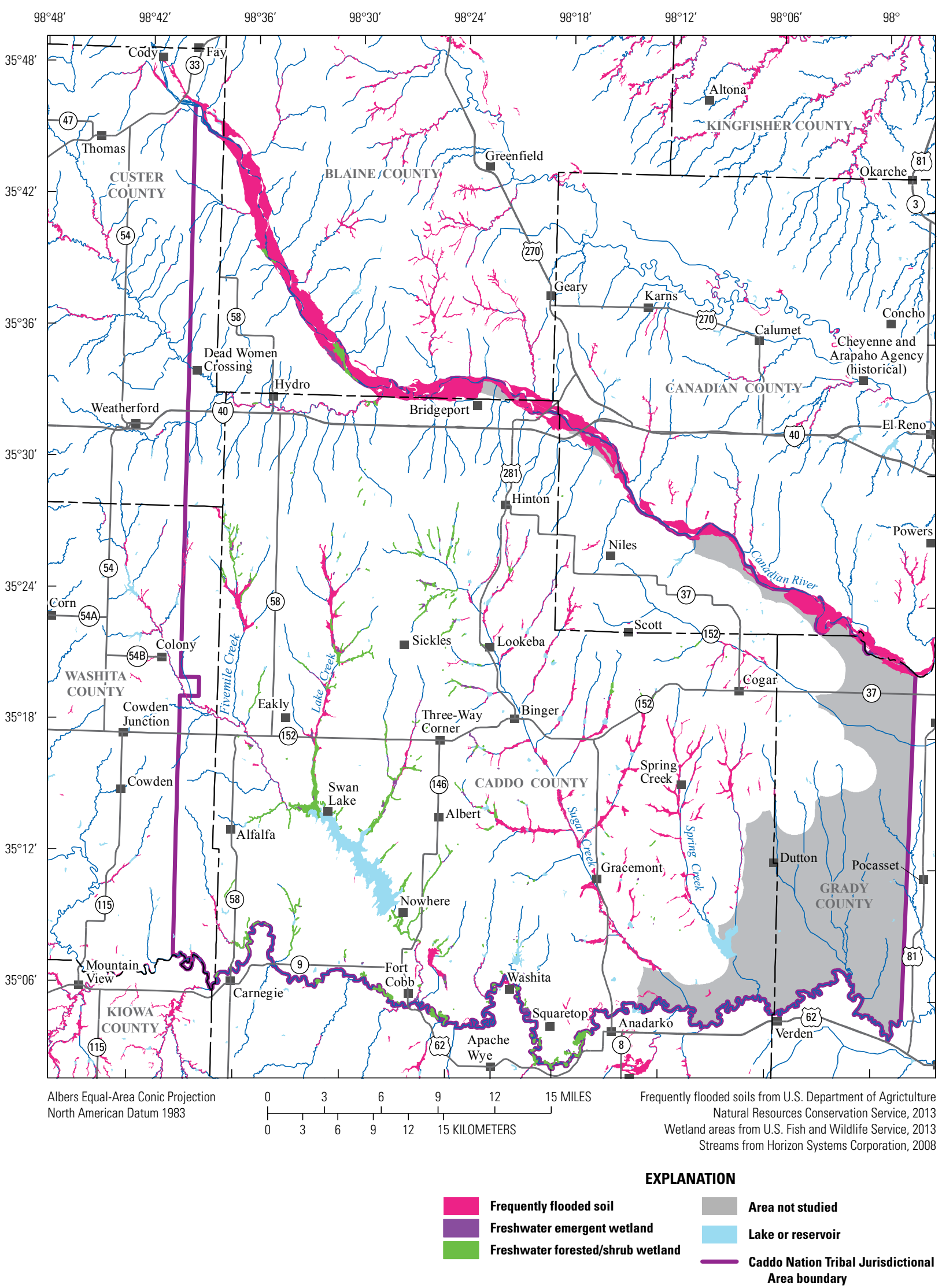

Figure 28. Locations of wetlands and frequently flooded soils in and around the Caddo Nation Tribal Jurisdictional Area, Oklahoma. 


\section{Potentiometric Surface and Regional Groundwater Flow, 2010}

Water levels measured from wells completed in the Rush Springs aquifer can be used to construct a potentiometricsurface map in the Rush Springs aquifer and to infer directions of groundwater flow. A potentiometric surface is the level at which water rises in a tightly cased well. Multiple potentiometric surfaces can be present in an aquifer. The potentiometric surface measured in wells for this report was intended to represent the shallowest water table in connection with the atmosphere through pore spaces in the rocks that make up the Rush Springs aquifer.

Water levels were measured synoptically in 29 wells completed in the Rush Springs aquifer in Caddo County and the Caddo Nation Tribal Jurisdictional Area (fig. 29). Most of the wells were used for domestic purposes and were completed at depths less than $200 \mathrm{ft}$ below land surface. Water levels were also measured in a few irrigation wells with completion depths of approximately 300-400 ft. Water levels were measured monthly starting in July 2010 and ending in January 2011. Water levels measured in wells were converted to the potentiometric surface by subtracting the water level from a land-surface altitude measured to the North American Vertical Datum of 1988 using a Global Positioning
System. The potentiometric altitudes were then assigned to the well locations and interpolated by using contours of equal altitude. These contours represent the potentiometric surface for the date measured. The shallowest groundwater table in this aquifer is assumed to be connected to the streams; therefore, point altitudes along streams were obtained from a USGS 10-meter (3.3-ft) digital elevation model and were used to interpolate the potentiometric surface. Groundwater flows from areas of high potentiometric altitudes to areas of low potentiometric altitudes perpendicular to contour lines. Thus, potentiometric contours can be used to infer regional groundwater-flow directions in the aquifer.

The potentiometric-surface map for July 2010 indicates that groundwater in the northern part of Caddo County flows regionally from north to south and discharges to streams that flow into Fort Cobb Reservoir (fig. 29). Regional groundwater flow in the southern part of Caddo County is mostly towards the Washita River, but some flow is to the southeast where groundwater discharges to other streams leaving the aquifer boundaries. Regional groundwater in the northeastern part of Caddo County flows toward the south, where groundwater discharges to tributaries of Sugar Creek. Similar regional flow patterns are seen in the January 2011 potentiometric-surface map (fig. 30), but potentiometric altitudes are lower than those in the July 2010 map (fig. 29). 
$98^{\circ} 40^{\prime}$

$98^{\circ} 20^{\prime}$

$98^{\circ}$

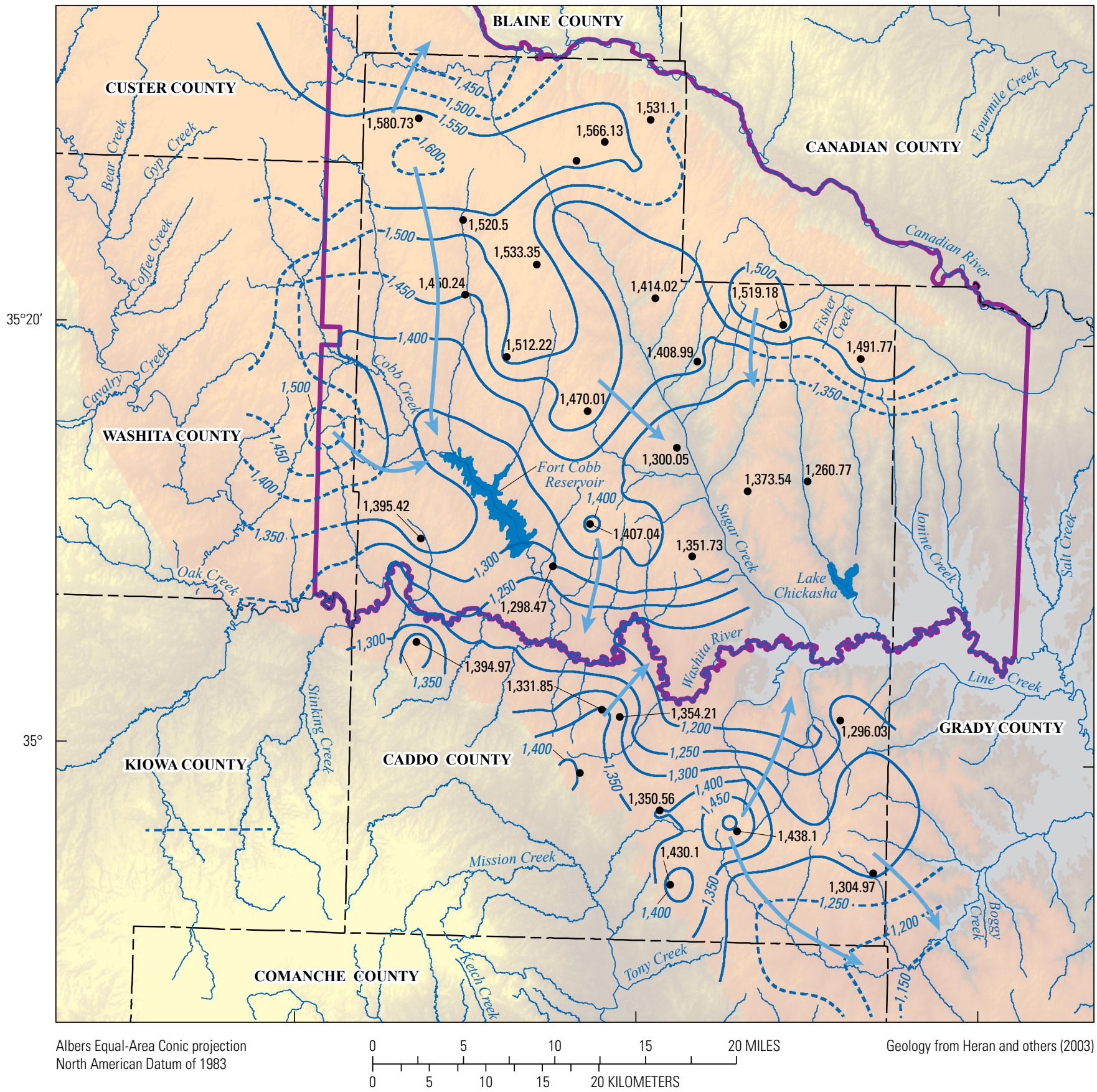

EXPLANATION
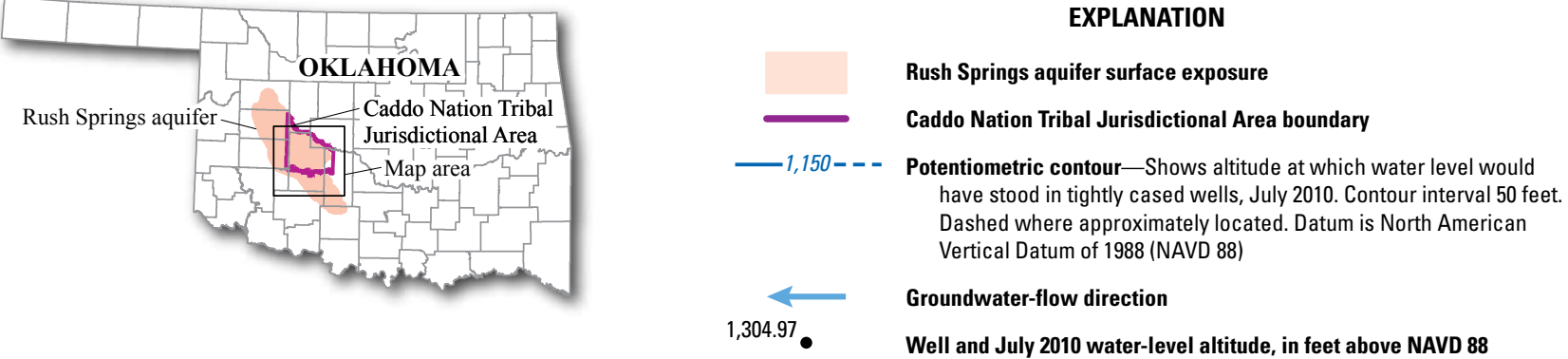

Figure 29. The potentiometric surface of the Rush Springs aquifer in Caddo County, Oklahoma, July 2010. 

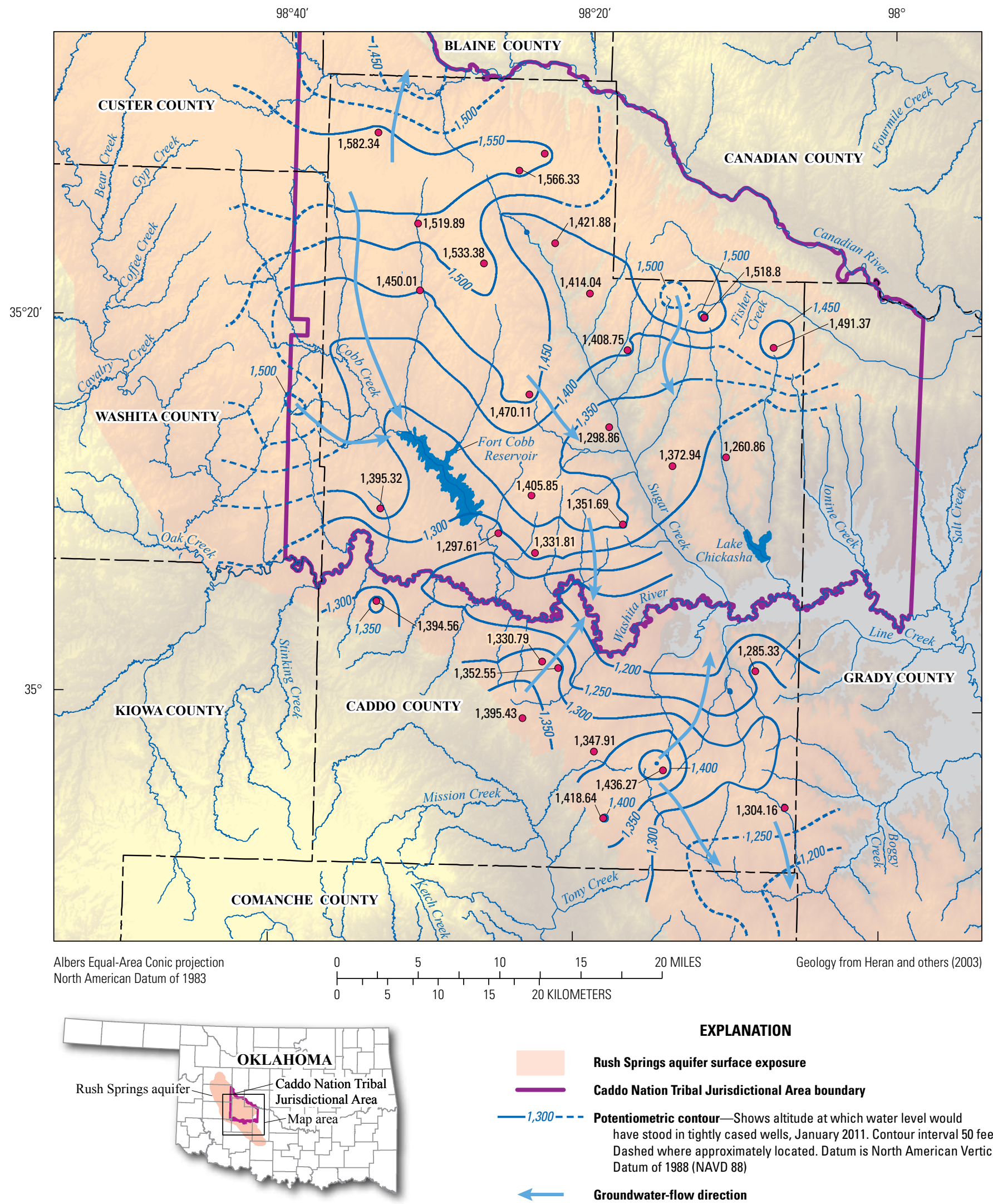

\section{EXPLANATION}

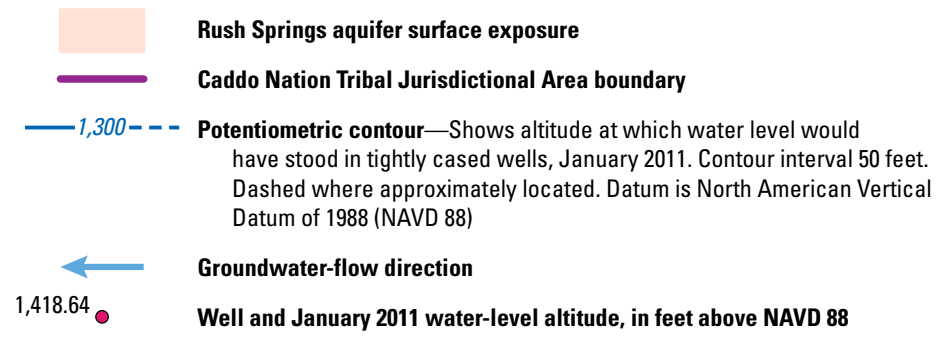

Figure 30. The potentiometric surface of the Rush Springs aquifer in Caddo County, Oklahoma, January 2011. 


\section{Groundwater-Level Fluctuations, 2010-13}

Groundwater-level monitors recorded fluctuations in the water table that can be caused by nearby pumping and changes from evapotranspiration and increasing or decreasing barometric pressure. Multiple wells with groundwater-level monitors can be used to determine aquifer-wide effects to water-table altitudes from causes such as variations in climate and water use.

Groundwater levels were recorded every 30 minutes in five wells by use of Level TROLL 500 vented pressure transducers and data collection platforms with real-time transmitting equipment in each well (fig. 1). These five wells were completed in the Rush Springs aquifer and ranged in depth from 210-350 ft below land surface (table 6). Groundwater-level measurements were transmitted in real time to the USGS National Water Information System (NWIS) database (U.S. Geological Survey, 2013). Groundwater levels measured by the vented pressure transducers were checked and corrected with groundwater levels measured with an electric tape at least every other month or when errors were noticed in the real-time data online.

Groundwater levels in the five wells in the Rush Springs aquifer generally decreased during the period October 2010 to June 2013 (figs. 31-38). The groundwater level in USGS well 350748098231101 near Gracemont, Okla., decreased approximately $3 \mathrm{ft}$ from October 2010 to June 2013 (fig. 31). The groundwater level in USGS well 351308098341601 near Alfalfa, Okla., decreased approximately $10 \mathrm{ft}$ from October 2010 to June 2013 (fig. 32). USGS well 351308098341601 near Alfalfa, Okla., was monitored prior to October 2010, and historical water levels indicated that the groundwater level in that well decreased approximately $34 \mathrm{ft}$ from August 1948 to June 2013 (fig. 33). The groundwater level in USGS well 351727098290401 Core 2 decreased approximately $13 \mathrm{ft}$ from October 2010 to June 2013 (fig. 34). USGS well 351727098290401 Core 2 was monitored prior to October 2010, and the groundwater level was $77 \mathrm{ft}$ below land surface in December 1989 and rose and declined several times to $86 \mathrm{ft}$ below land surface in June 2013 in that well (fig. 35). The groundwater level in USGS well 352423098341701 near Eakly, Okla., decreased approximately $7 \mathrm{ft}$ from October 2010 to June 2013 (fig. 36). USGS well 352423098341701 near Eakly, Okla., was monitored prior to October 2010, and historical water levels show that the groundwater level in that well decreased from about $58 \mathrm{ft}$ below land surface to $75 \mathrm{ft}$ below land surface from 1965 to 1986 and then rose to $56 \mathrm{ft}$ below land surface in October 2010 (fig. 37). The groundwater level in USGS well 352802098191601 near Hinton, Okla., declined approximately $2 \mathrm{ft}$ from October 2010 to June 2013 (fig. 38).

Table 6. Real-time continuous groundwater-level monitoring wells in the area underlain by the Rush Springs aquifer, southwestern Oklahoma, October 2010-June 2013.

\begin{tabular}{clc}
\hline $\begin{array}{c}\text { Well } \\
\text { identifier }\end{array}$ & \multicolumn{1}{c}{$\begin{array}{c}\text { Station } \\
\text { name }\end{array}$} & $\begin{array}{c}\text { Well } \\
\text { depth } \\
\text { (feet) }\end{array}$ \\
\hline 350748098231101 & $08 \mathrm{~N}-11 \mathrm{~W}-32$ BBA 1 Gracemont & 350 \\
351308098341601 & $09 \mathrm{~N}-13 \mathrm{~W}-28$ DDD 1 Alfalfa GW Well & 335 \\
351727098290401 & $10 \mathrm{~N}-12 \mathrm{~W}-32$ DDD 1, Core 2 GW Well & 257 \\
352423098341701 & $11 \mathrm{~N}-13 \mathrm{~W}-21$ DDD 1 Eakly GW Well & 210 \\
352802098191601 & 12N-11W-36 CCA 1 Hinton & 225 \\
\hline
\end{tabular}




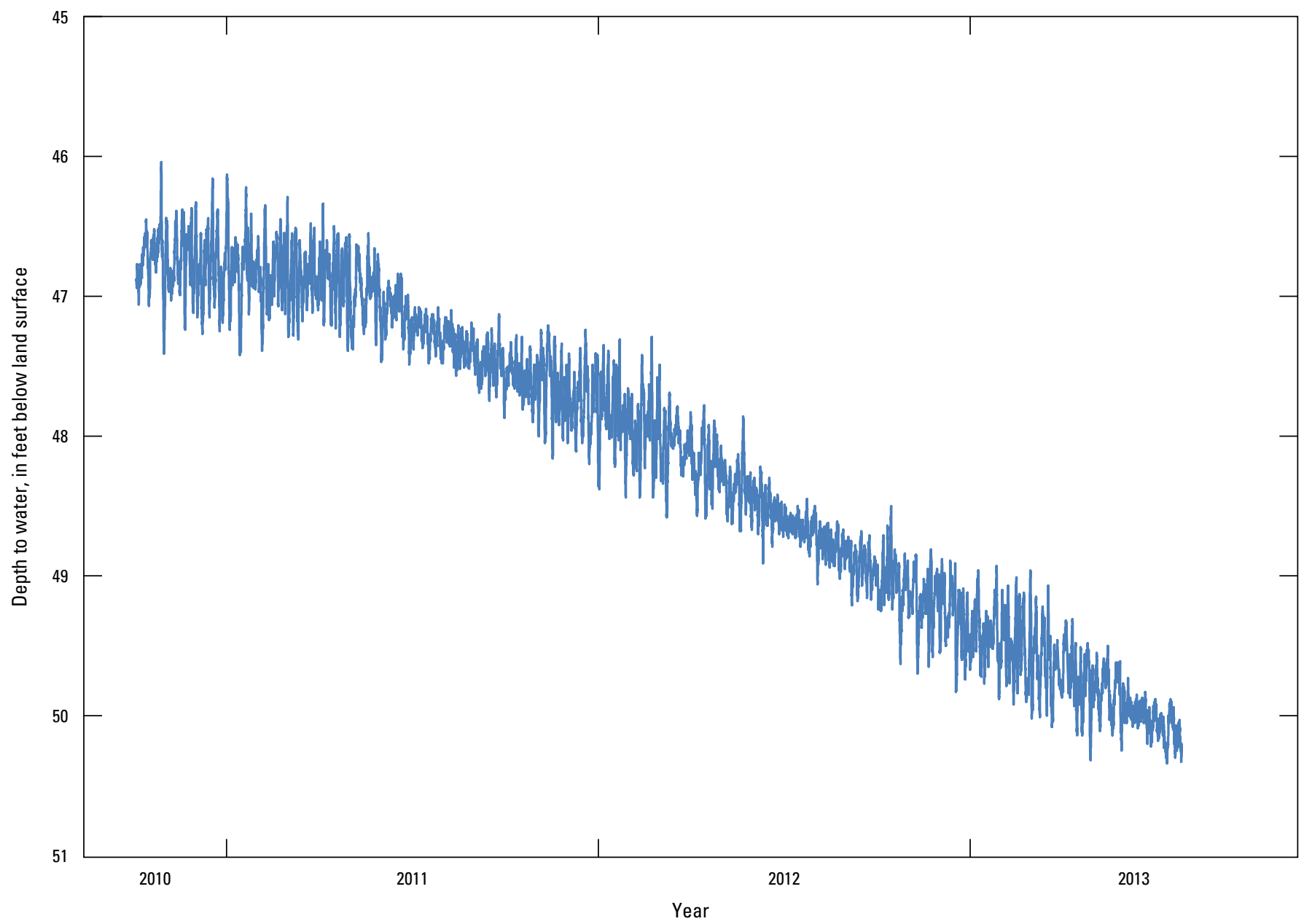

Figure 31. Groundwater levels measured in U.S. Geological Survey well 350748098231101 near Gracemont, Oklahoma, October 2010June 2013. 


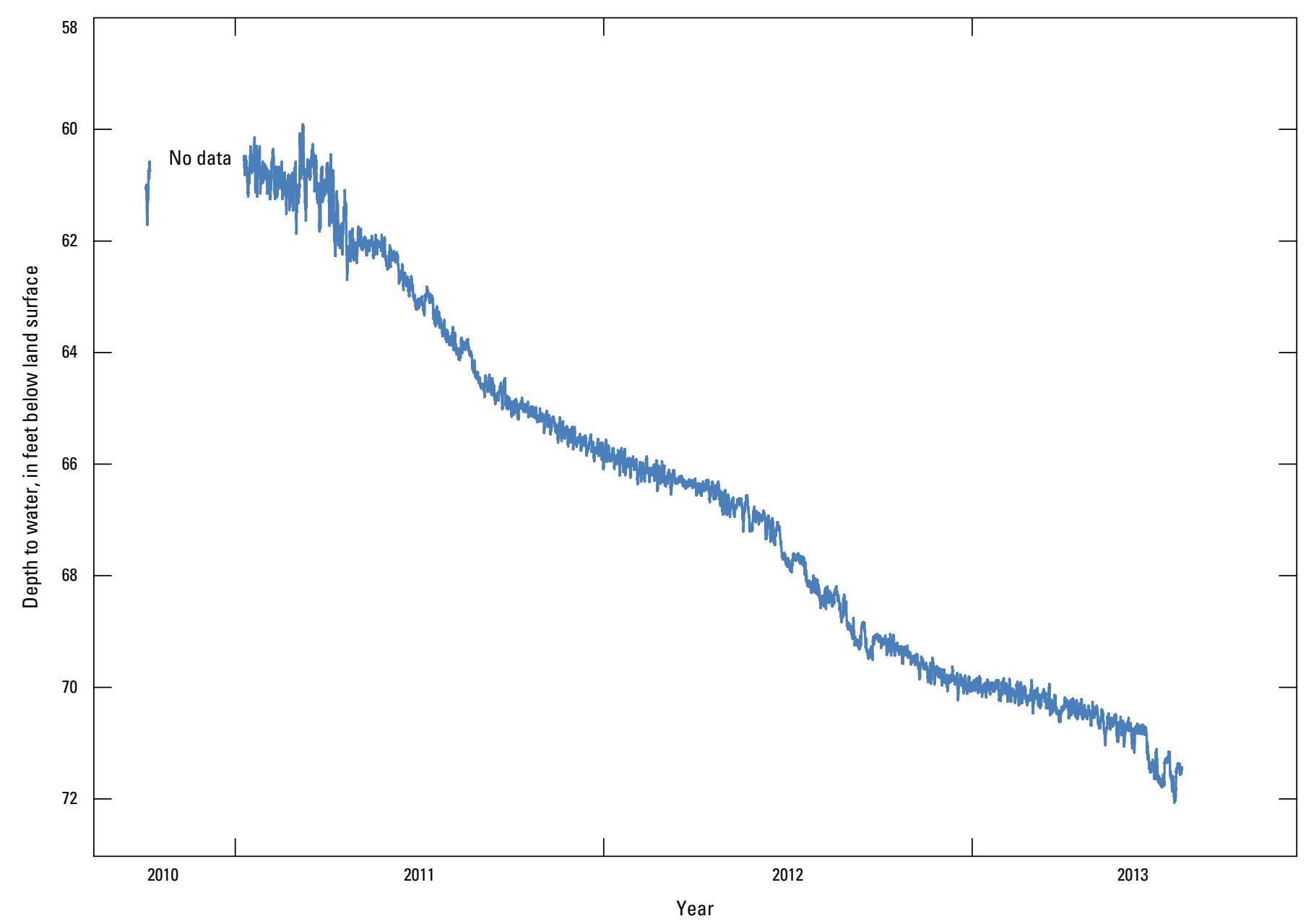

Figure 32. Groundwater levels measured in U.S. Geological Survey well 351308098341601 near Alfalfa, Oklahoma, October 2010-June 2013. 
44 Evaluation of Groundwater and Surface-Water Interactions in the Caddo Nation Tribal Jurisdictional Area

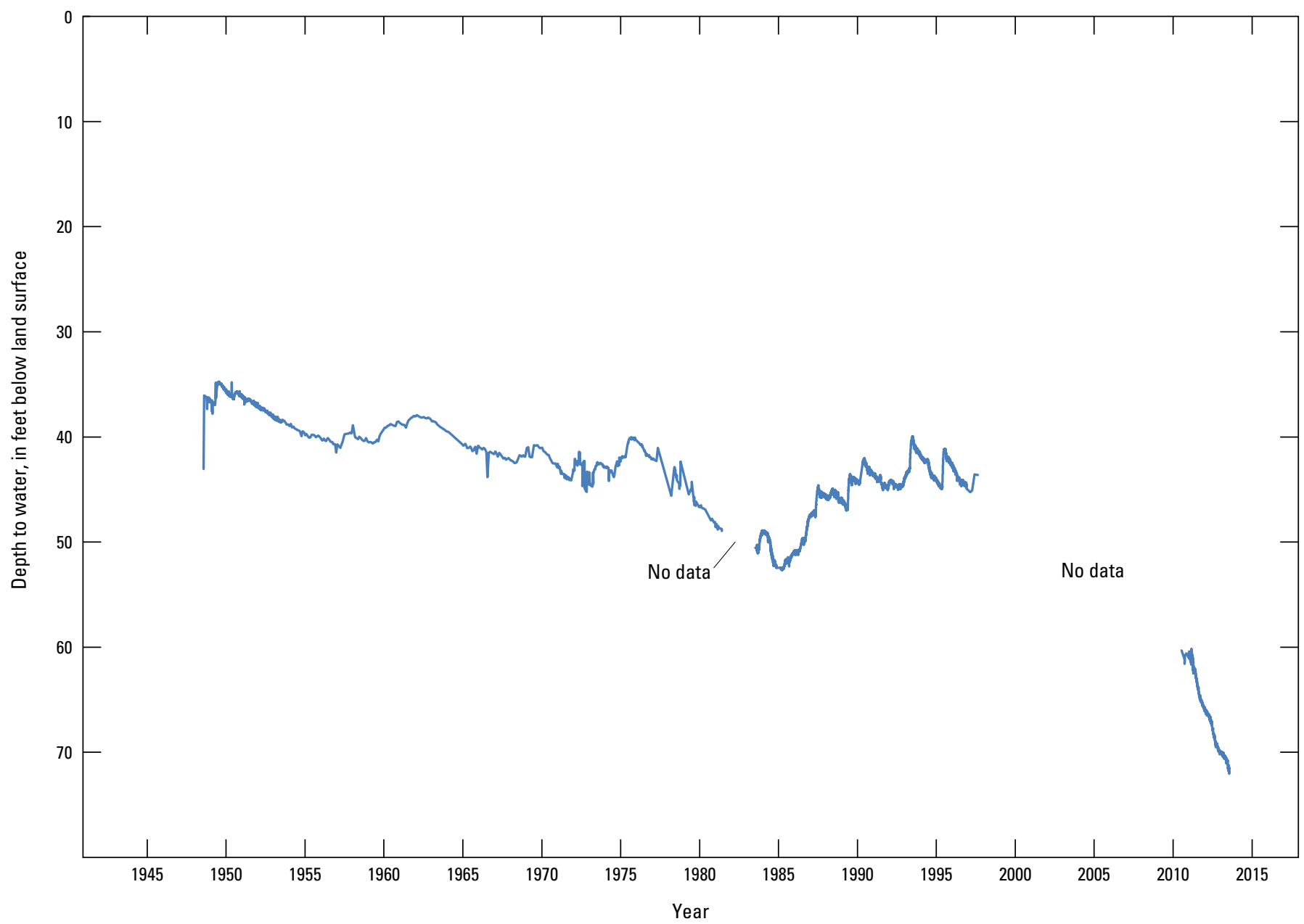

Figure 33. Groundwater levels measured in U.S. Geological Survey well 351308098341601 near Alfalfa, Oklahoma, August 1948-June 2013. 


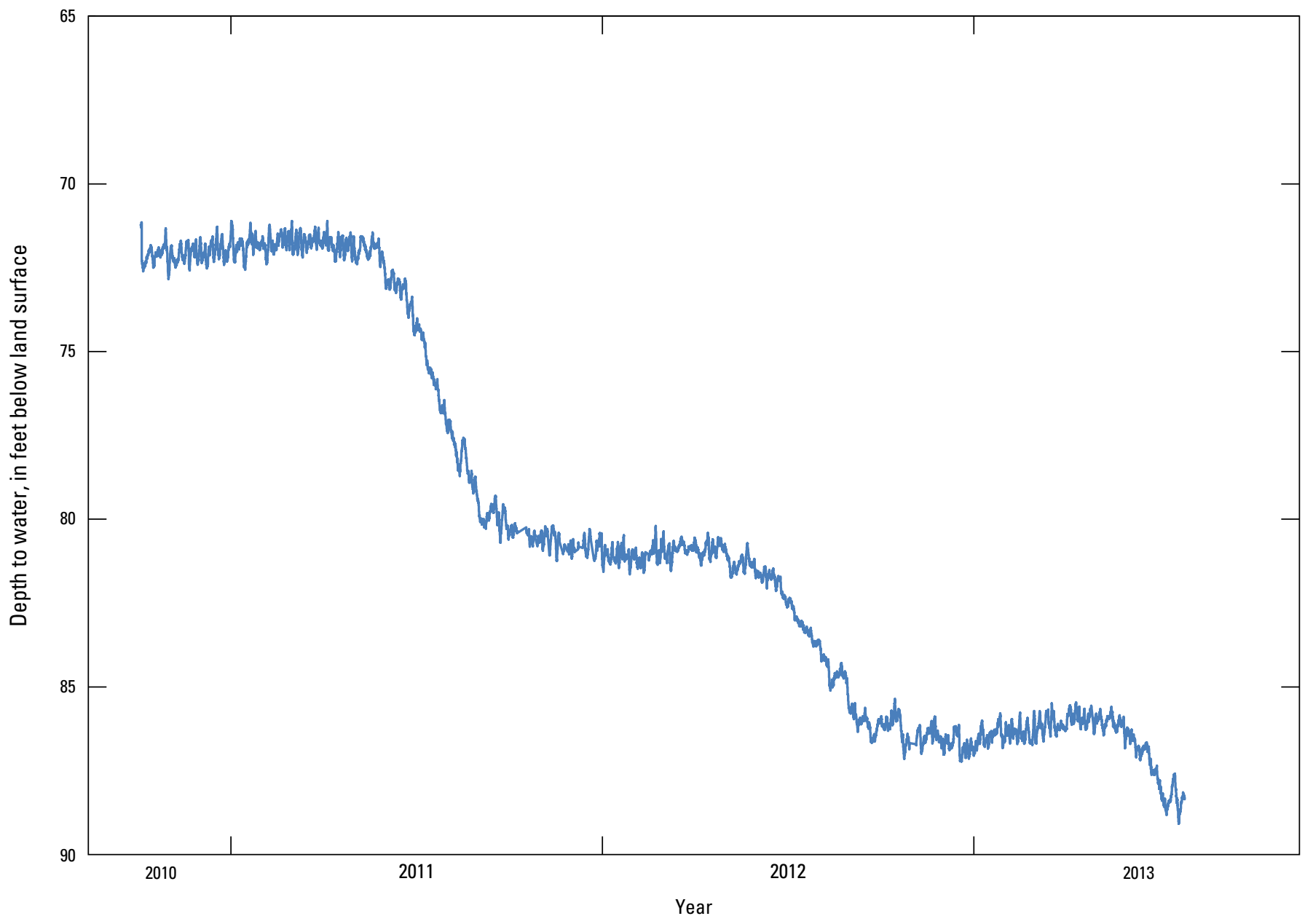

Figure 34. Groundwater levels measured in U.S. Geological Survey well 351727098290401 Core 2, 0ctober 2010-June 2013. 


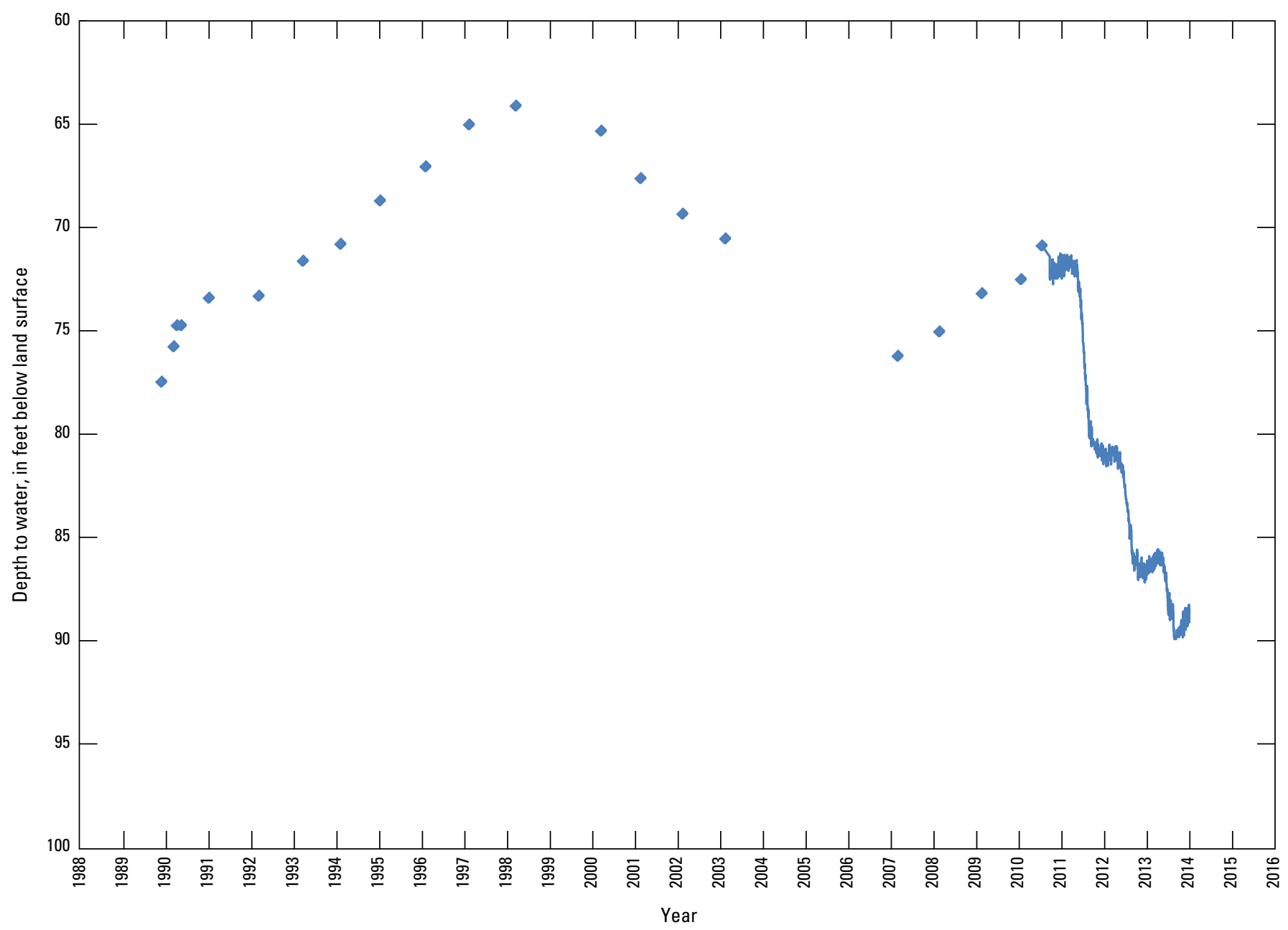

Figure 35. Groundwater levels measured in U.S. Geological Survey well 351727098290401 Core 2, December $1989-J u n e ~ 2013$. 


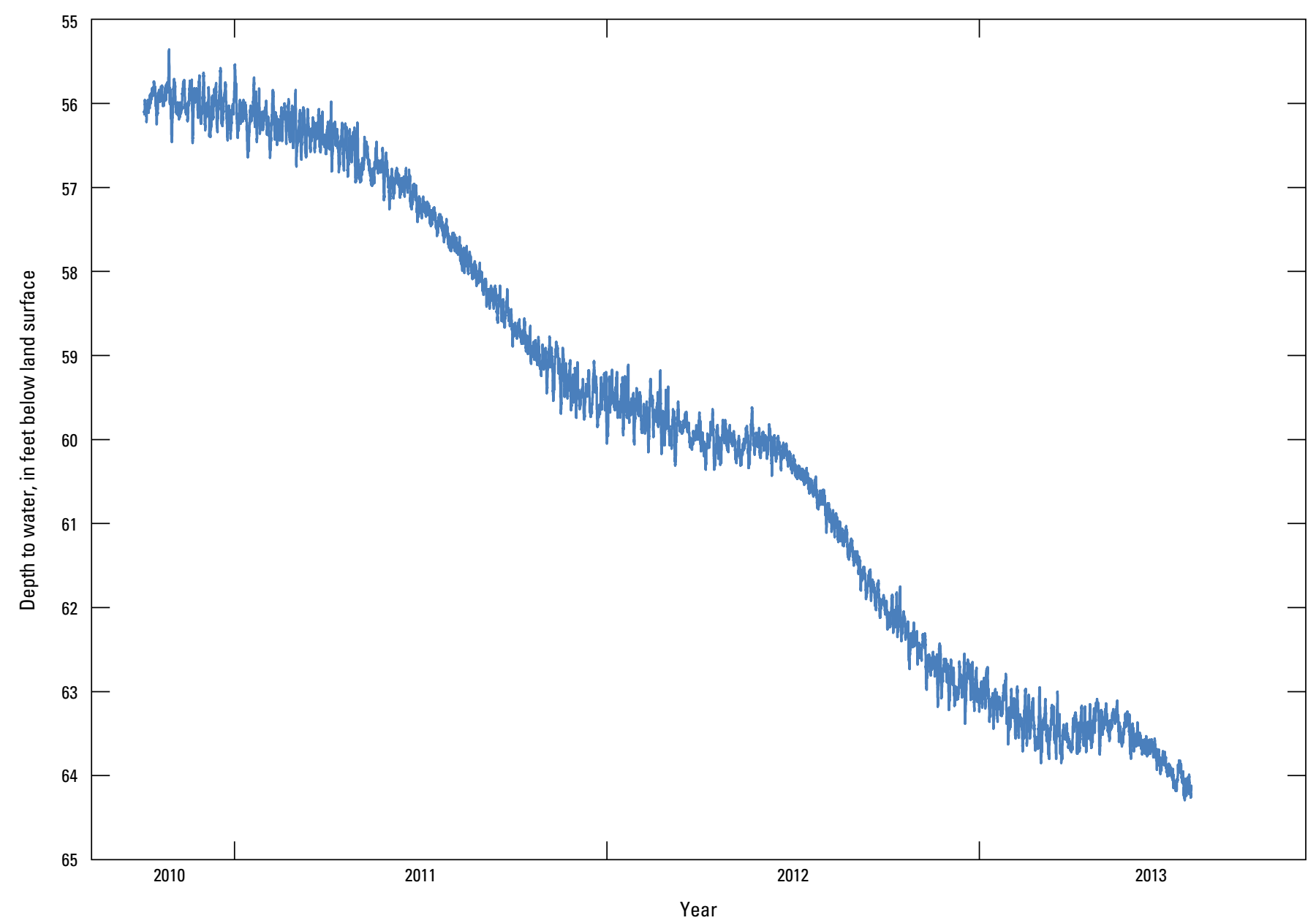

Figure 36. Groundwater levels measured in U.S. Geological Survey well 352423098341701 near Eakly, Oklahoma, October 2010-June 2013. 


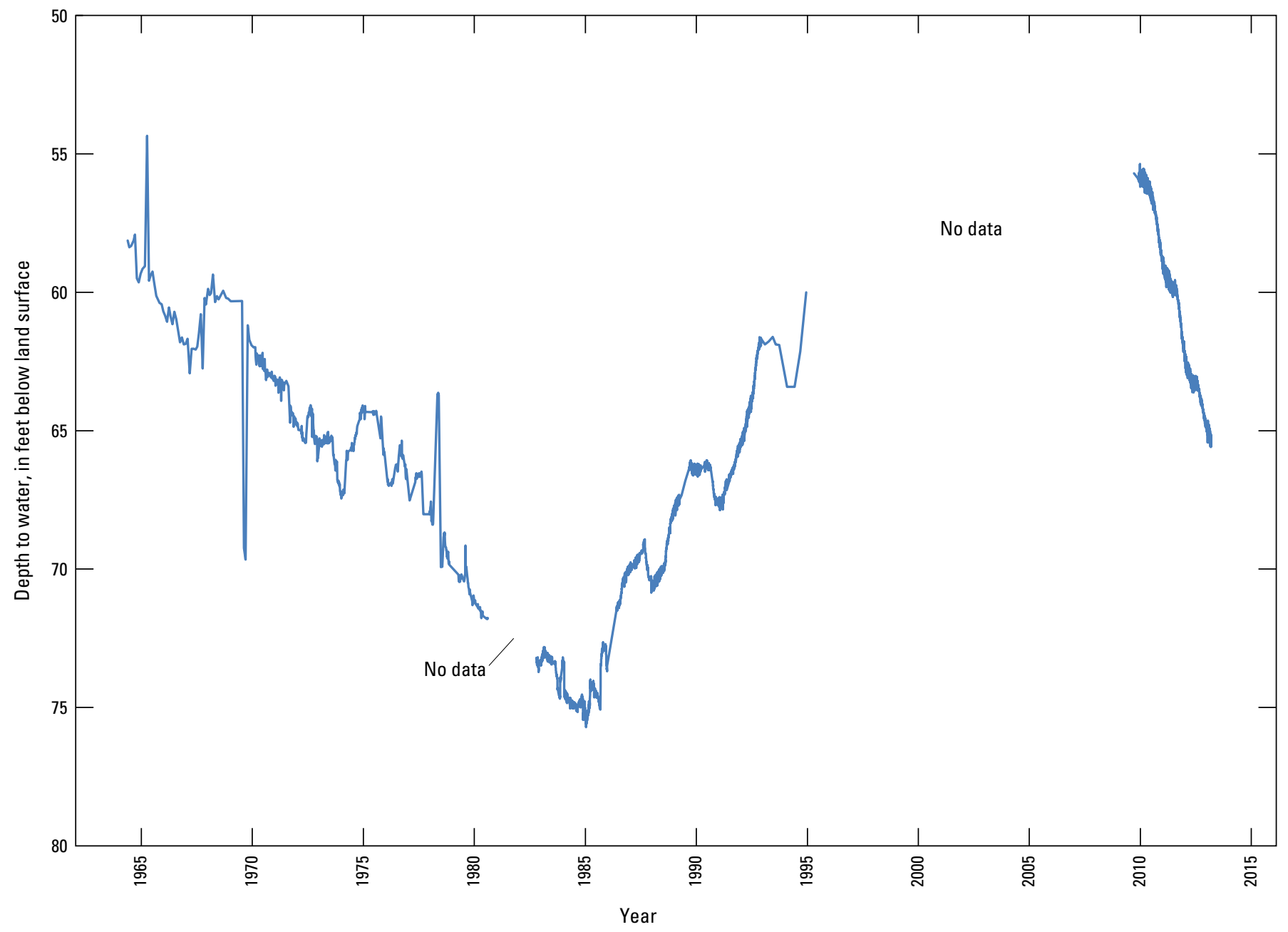

Figure 37. Groundwater levels measured in U.S. Geological Survey well 352423098341701 near Eakly, Oklahoma, April 1965-June 2013. 


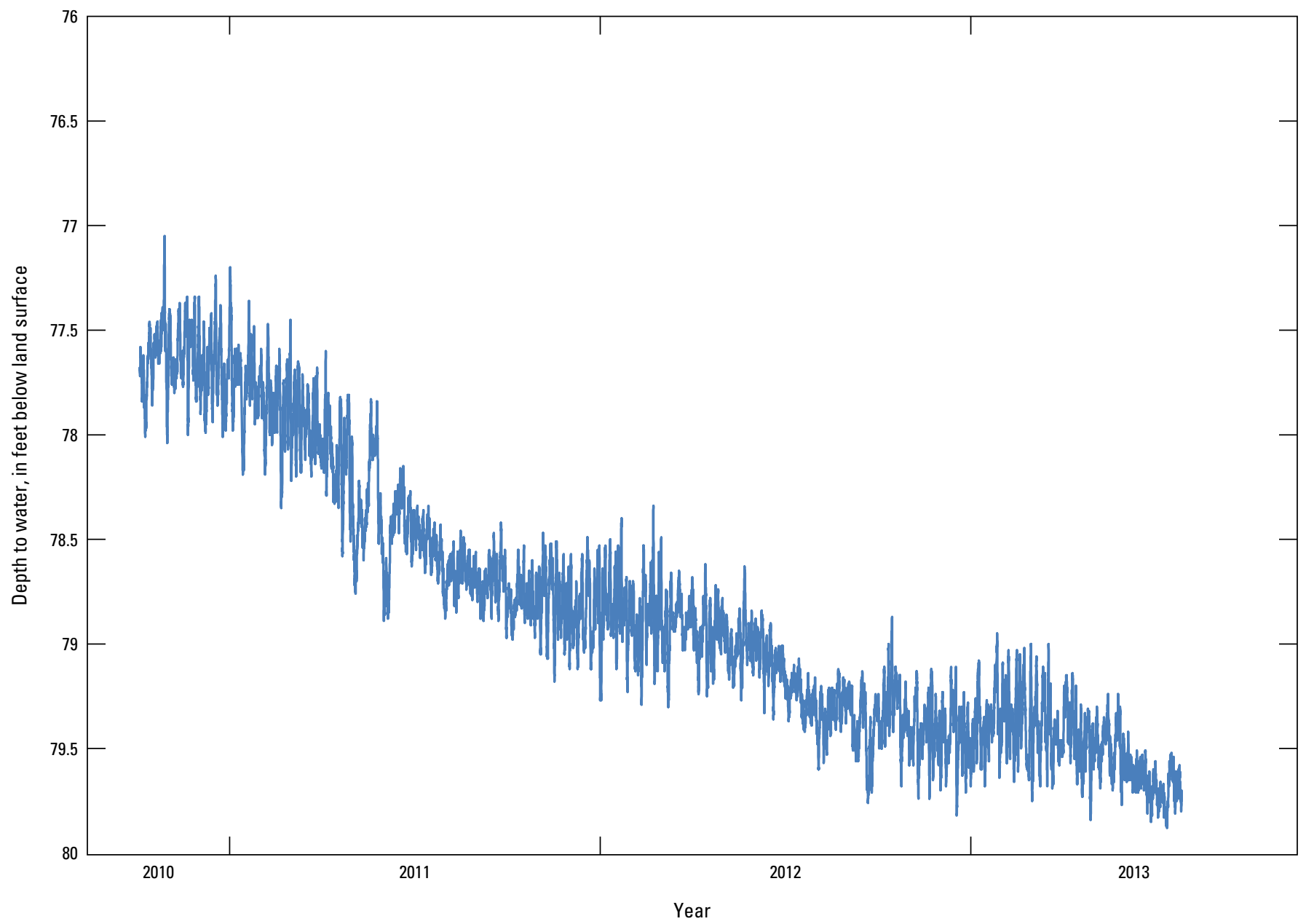

Figure 38. Groundwater levels measured in U.S. Geological Survey well 352802098191601 near Hinton, Oklahoma, October 2010-June 2013. 
During the summer months of 2011 and 2012, declining water levels were measured in USGS well 351308098341601 near Alfalfa, Okla. (fig. 32), USGS well 351727098290401 Core 2 (fig. 34), and USGS well 352423098341701 near Eakly, Okla. (fig. 36), which probably were caused by lack of precipitation (fig. 39) and increased withdrawals from the aquifer. There were periods of increased precipitation from October to December 2011, March to June 2012, and August to September 2012 (fig. 39). Water levels in USGS well 351308098341601 near Alfalfa, Okla., started to decline in May 2011. The timing of water-level recovery of this well is difficult to determine because water levels continued to decline into the next year (2012), but the rate of decline decreased from November 2011 to April 2012. Groundwater levels measured in USGS well 351727098290401 Core 2 (fig. 34) began to decline in May 2011 and began to recover in October 2011. Groundwater levels measured in USGS well 352423098341701 near Eakly, Okla. (fig. 36), started to decline in May 2011 and began to recover in November 2011. Similar decline and recovery patterns were observed in 2012 for groundwater levels measured in USGS well 352423098341701 near Eakly, Okla. Decreasing groundwater levels in these three wells during the summer months, along with the steady decline in groundwater levels in USGS well 350748098231101 near Gracemont, Okla. (fig. 31), and USGS well 352802098191601 near Hinton, Okla. (fig. 38), indicate that more water was flowing out of the groundwater system than into the groundwater system from October 2010 to June 2013. Groundwater levels measured in these five wells indicate that there was a negative change in storage in the Rush Springs aquifer from October 2010 to June 2013.

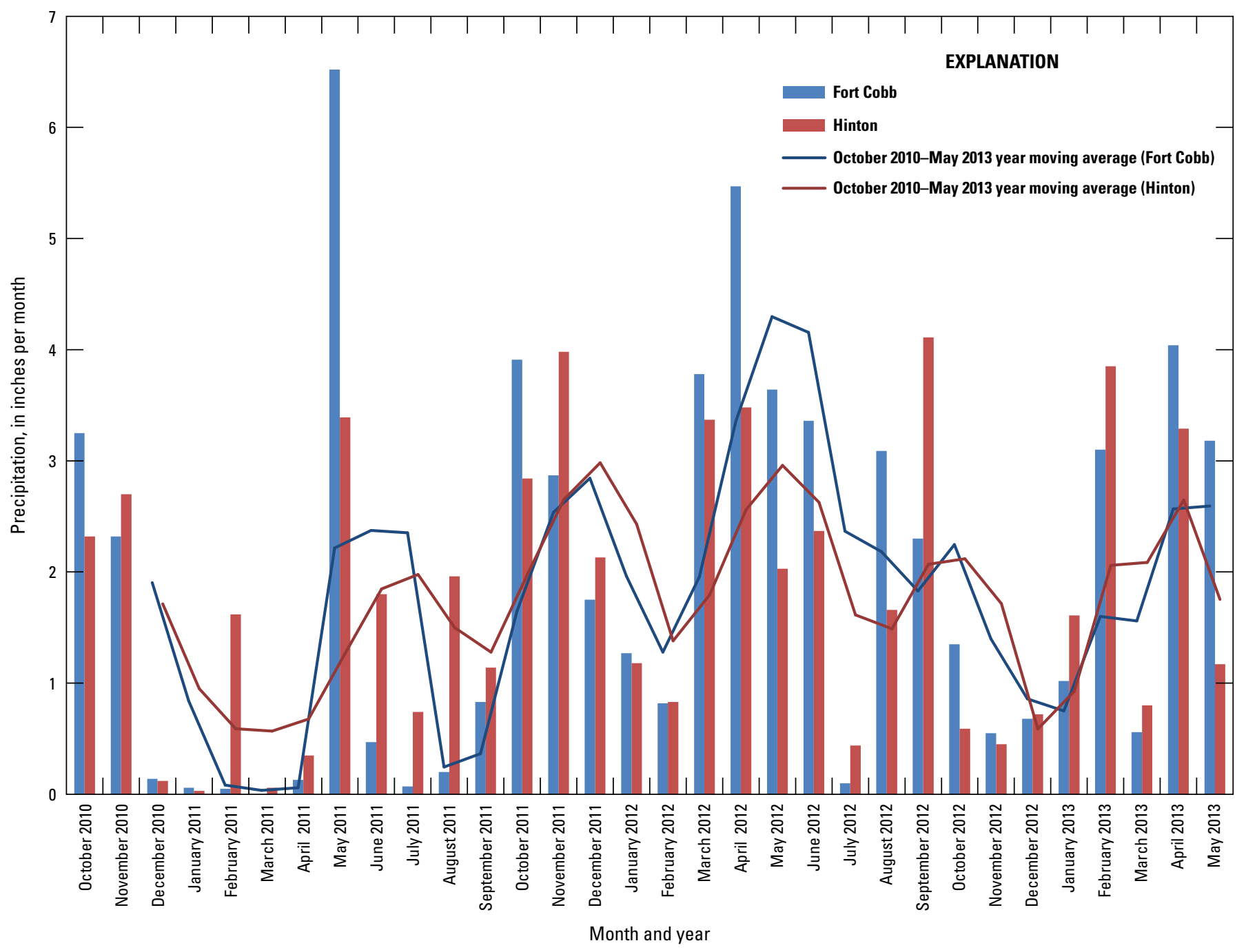

Figure 39. Monthly precipitation for Hinton and Fort Cobb Mesonet Stations (see fig. 1 for locations), 0klahoma, 0ctober 2010-May 2013. 
A recording barometer was put in the gage house of the USGS well 352802098191601 near Hinton, Okla., to monitor barometric pressure for comparison to groundwater levels measured in that well during February and March 2013, when evapotranspiration would be minimal to none (fig. 40). Hourly fluctuations in groundwater levels throughout each day, as shown in figures 31-38, were primarily caused by increasing or decreasing barometric pressure. Groundwater levels were monitored by using a vented pressure transducer to account for changes in groundwater levels in each well with increasing or decreasing barometric pressure. The fact that these groundwater levels were measured with vented pressure transducers and that the groundwater levels responded to changes in barometric pressure indicates that the unconfined part of the Rush Springs aquifer has a high barometric efficiency (fig. 40). This change in groundwater levels because of changes in barometric pressure also was described by Tanaka and Davis (1963). Groundwater levels in unconfined parts of the Rush Springs aquifer rise quickly with a decrease in barometric pressure and fall quickly with an increase in barometric pressure. The confined part of the Rush Springs aquifer probably would respond differently to changes in barometric pressure and would have a relatively low barometric efficiency. Response caused by barometric pressure needs to be considered when evaluating hourly to daily changes in groundwater levels, which also can be caused by evapotranspiration, nearby pumping, or local recharge (Freeze and Cherry, 1979).

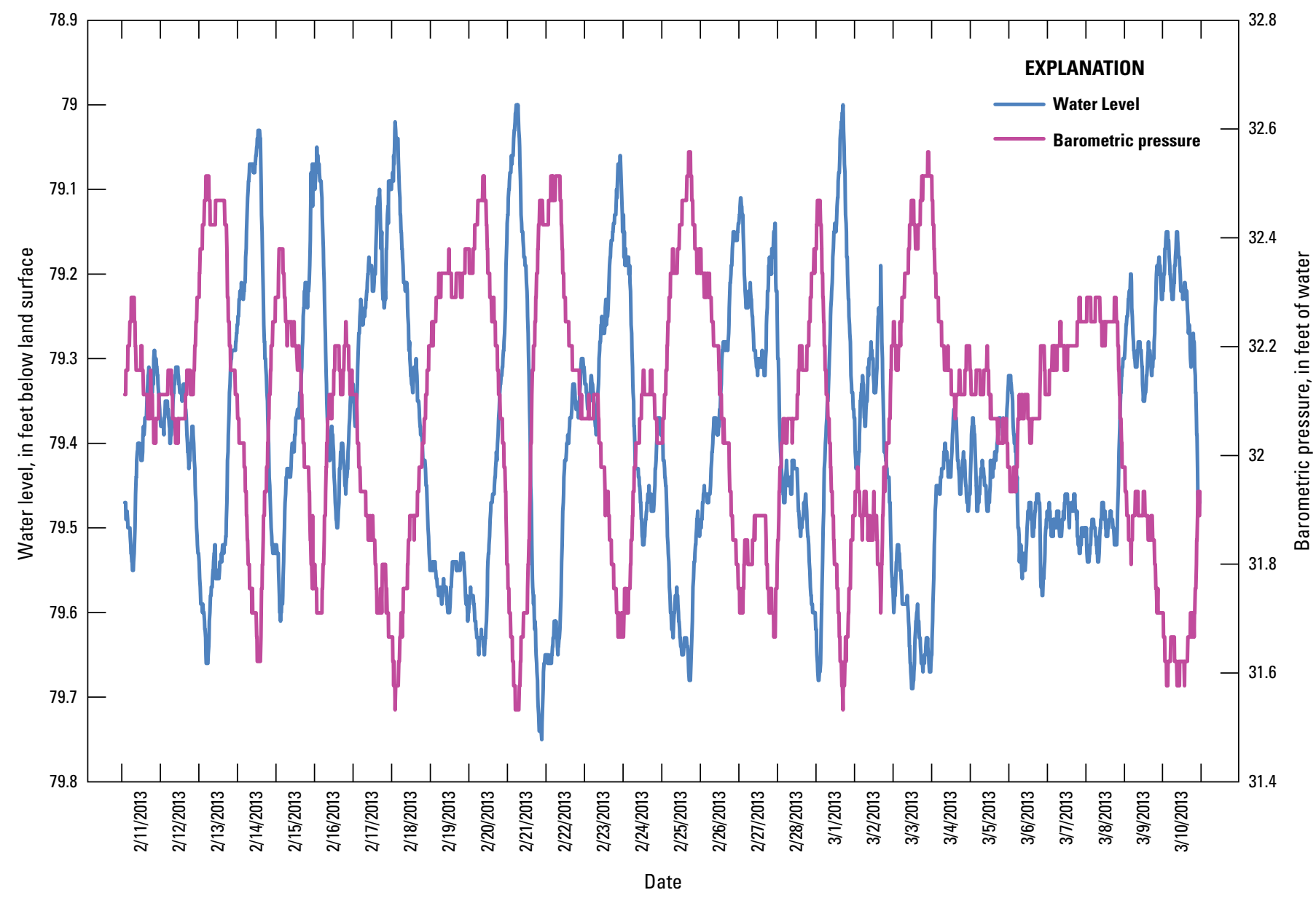

Figure 40. Groundwater levels monitored with a vented pressure transducer and barometric pressure at U.S. Geological Survey well 352702098191601 near Hinton, Oklahoma, showing barometric efficiency typical of the unconfined part of the Rush Springs aquifer. 


\section{Summary}

Streamflows, springs, and wetlands are important natural and cultural resources to the Caddo Nation. Consequently, the Caddo Nation is concerned about the vulnerability of the Rush Springs aquifer to overdrafting and whether the aquifer will continue to be a viable source of water to tribal members and other local residents in the future. The U.S. Geological Survey (USGS), in cooperation with the Caddo Nation, the Bureau of Indian Affairs, and the Bureau of Reclamation, initiated a multiyear study to provide information and tools to assist with management and protection of water resources in the Caddo Nation Tribal Jurisdictional Area and to help develop a Caddo Nation comprehensive water plan.

This report provides information on the evaluation of groundwater and surface-water resources in the Caddo Nation Tribal Jurisdictional Area, and in particular, information that describes the hydraulic connection between the Rush Springs aquifer and springs and streams overlying the aquifer. This report also includes data and analyses of base flow, evidence for groundwater and surface-water interactions, locations of springs and wetland areas, groundwater flows interpreted from potentiometric-surface maps, and hydrographs of water levels monitored in the Caddo Nation Tribal Jurisdictional Area.

Flow in streams overlying the Rush Springs aquifer, on average, were composed of 50 percent base flow for most years. Monthly mean base flow appeared to maintain streamflows throughout each year, but periods of zero flow were documented in the daily hydrographs for most sites, typically in the summer months, indicating that these streams were not always perennial and were affected by longer periods of no precipitation. Other potential causes in the decline of streamflow during the summer are water use and evaporation from streams and withdrawals from the Rush Springs aquifer or from the overlying alluvial aquifer.

A pneumatic slug-test technique was used at 15 sites to determine the horizontal hydraulic conductivity of streambed sediments in streams overlying the Rush Springs aquifer. Converting horizontal hydraulic conductivities $(\mathrm{Kh})$ from the slug-test analyses to vertical hydraulic conductivities $(\mathrm{Kv})$ by using a ratio of $\mathrm{Kv} / \mathrm{Kh}=0.1$ indicates that vertical hydraulic conductivity in the streambed sediments overlying the Rush Springs aquifer ranged from 0.1 to 8.6 feet per day (ft/d).

A hydraulic potentiomanometer was used in the streambed sediments and the stream at the same 15 sites at which slug tests were done to determine the direction of water flow and the magnitude of hydraulic gradients between surface water and groundwater. At 6 of the 15 sites, direction of water flow was from the streambed sediments to the stream (gaining), and the magnitude of the hydraulic-head gradient ranged from 0.003 to 0.323 . At the nine sites with direction of water flow from the stream to the streambed sediments (losing), hydraulic-head gradients ranged from 0.004 to 0.076 .

The flux of water across the stream/alluvium interface was measured directly at five locations by using seepage meters. The change in water volume in a collector bag was divided by the area of the storage drum to normalize and determine a flux velocity. This flux velocity represented the measured flow rate across the stream/alluvium interface. Volumetric flow rates and flux velocities varied with location and time. At the Cobb Creek at Highway 152 (Oklahoma State Highway 152) and Willow Creek at 1230 Road sites, negative flux velocities were measured, indicating flow of water from the stream to the alluvium (losing) ranging from 0.003 to $0.140 \mathrm{ft} / \mathrm{d}$. At the Cobb Creek at 1150 Road near Colony and Lake Creek at 1160 Road sites, positive flux velocities were measured, indicating water flow from the alluvium to the stream (gaining) ranging from 0.005 to $0.039 \mathrm{ft} / \mathrm{d}$. At the Fivemile Creek at 1170 Road site, positive and negative flux velocities were measured in the streambed. The vertical hydraulic conductivity (Kv) using Darcy's law ranged from 0.1 to $13 \mathrm{ft} / \mathrm{d}$ for all sites. The vertical hydraulic conductivities determined using Darcy's law were similar to the streambed hydraulic conductivities estimated from the slug tests, using a ratio of $\mathrm{Kv} / \mathrm{Kh}=0.1$, that ranged from $0.1 \mathrm{ft} / \mathrm{d}$ to $8.6 \mathrm{ft} / \mathrm{d}$.

The groundwater and surface-water interaction data collected at streamflow-gaging station 07325800 (Cobb Creek near Eakly, Okla.) showed that the bedrock groundwater, alluvial groundwater, and surface-water resources were in hydraulic connection in the study area. Because of this hydrologic connection, large perennial streams in the study area may change from gaining to losing streams in the summer. The timing and extent of this change may be influenced by regional withdrawal of groundwater for irrigation in the summer growing season. Irrigation wells placed closer to streams were likely to cause a greater and more immediate effect on alluvial groundwater levels and stream stages than wells placed farther from streams. Largecapacity irrigation wells, even those completed hundreds of feet below land surface in the bedrock aquifer, can induce surface-water flow from nearby streams by lowering alluvial groundwater levels below the stream altitude.

Documentation of springs and wetlands is important because these areas mark the intersection of groundwater with surface water and are therefore good indicators of change in the hydrologic system. When groundwater levels fall as a result of less than normal precipitation, such as during 2011, springs may stop discharging water, and wetland areas may dry up. Spring and wetland inventories were conducted in a 2011-12 field survey of the Caddo Nation Tribal Jurisdictional Area, and precipitation had been below normal in 2011. Twenty-five springs visible from public roads and paths were documented during that survey. Two of these springs were in Red Rock Canyon State Park. Most of the springs were in upland draws on the flanks of a topographic ridge that trends southeast from Weatherford to Anadarko. This ridge is believed to coincide with a groundwater divide separating groundwater flow between the Sugar Creek and Cobb Creek surface-water drainage systems. All of the 25 springs were flowing at the time of the field survey, but none of the springs were discharging enough water to obtain accurate discharge measurements. All documented springs were estimated to be discharging less than 1 cubic foot per second. Wetlands were identified primarily by using a combination of data 
sources. Two wetland classes are common in the study area $\left(1,153.73\right.$ square miles $\left.\left[\mathrm{mi}^{2}\right]\right)$ : freshwater emergent wetlands, which comprise $3.34 \mathrm{mi}^{2}$ ( 0.29 percent of the study area), and freshwater forested/shrub wetlands, which comprise $13.37 \mathrm{mi}^{2}$ (1.16 percent of the study area).

Groundwater levels were measured in 29 wells completed in the Rush Springs aquifer in Caddo County and the Caddo Nation Tribal Jurisdictional Area. Groundwater levels were measured monthly starting in July 2010 and ending in January 2011. The potentiometric-surface map for July 2010 indicates that regional groundwater flow in the northern part of Caddo County was from north to south and that groundwater discharged to streams that flow into Fort Cobb Reservoir. Regional groundwater flow in the southern part of Caddo County was mostly toward the Washita River, but some groundwater flow was to the southeast, where some groundwater discharged to other streams flowing past the aquifer boundaries. In the northeastern part of Caddo County, groundwater flowed to the south, where it discharged to tributaries of Sugar Creek. Similar regional flow patterns were measured in January 2011, but potentiometric altitudes were lower in January 2011 than in July 2010.

Groundwater levels were measured every 30 minutes in five wells by using a vented pressure transducer and a datacollection platform with real-time transmitting equipment in each well. These five wells ranged in depth from 210 to 350 feet below land surface. Groundwater levels in the five wells completed in the Rush Springs aquifer generally decreased from October 2010 to June 2013. Three wells with decreasing groundwater levels during the summer months and the steady decline in water levels indicated that more water flowed from the groundwater system than flowed into the groundwater system from October 2010 to June 2013. Groundwater levels in these five wells indicated a negative change in storage in the Rush Springs aquifer from October 2010 to June 2013 because of a lack of precipitation and withdrawals from the aquifer.

\section{References}

Becker, M.F., and Runkle, D.L., 1998, Hydrogeology, water quality, and geochemistry of the Rush Springs aquifer, western Oklahoma: U.S. Geological Survey WaterResources Investigations Report 98-4081, 37 p.

Boggs, Sam, Jr., 2001, Principles of sedimentology and stratigraphy ( 3 d ed.): Upper Saddle River, New Jersey, Prentice Hall, 726 p.

Bouwer, Herman, 1989, The Bouwer and Rice slug test-An update: Ground Water, v. 27, no. 3, p. 304-309.

Bouwer, Herman, and Rice, R.C., 1976, A slug test method for determining hydraulic conductivity of unconfined aquifers with completely or partially penetrating wells: Water Resources Research, v. 12, no. 3, p. 423-428.
Butler, J.J., Jr., 2002, A simple correction for slug tests in small-diameter wells: Ground Water, v. 40, no. 3, p. 303-307.

Darcy, Henry, 1856, Les fontaines publiques de la ville de Dijon: Dalmont, Paris, 647 p., and atlas.

Fellows, C.R., and Brezonik, P.L., 1980, Seepage flow into Florida lakes: Water Resources Bulletin, v. 16, no. 4, p. 635-641.

Freeman, L.A., Carpenter, M.C., Rosenberry, D.O., Rousseau, J.P., Unger, Randy, and McLean, J.S., 2004, Use of submersible pressure transducers in water-resources investigations: U.S. Geological Survey Techniques of Water-Resources Investigations, book 8, chap. A3, 65 p.

Freeze, R.A., and Cherry, J.A., 1979, Groundwater: Englewood Cliffs, New Jersey, Prentice-Hall, Inc., 604 p.

Heran, W.D., Green, G.N., and Stoeser, D.B., 2003, A digital geologic map database for the State of Oklahoma: U.S. Geological Survey Open-File Report 2003-247, 12 digital geologic maps.

Hinsby, Klaus, Bjerg, P.L., Andersen, L.J., Skov, Bent, and Clausen, E.V., 1992, A mini-slug test method for determination of a local hydraulic conductivity of an unconfined sandy aquifer: Journal of Hydrology, v. 136, p. $87-106$.

Horizon Systems Corporation, 2008, National Hydrography Dataset Plus Version 1 (NHDPlusV1): Horizon Systems Corporation, accessed November 13, 2008, at http://www. horizon-systems.com/nhdplus/.

Hyder, Zafar, Butler, J.J., Jr., McElwee, C.D., and Liu, Wenzhi, 1994, Slug tests in partially penetrating wells: Water Resources Research, v. 30, no. 11, p. 2945-2957.

Hydrosolve, Inc., 2011, AQTESOLV for Windows: Hydrosolve, Inc., accessed January 2011, at http://www. aqtesolv.com.

Meinzer, O.E., 1923, Outline of ground-water hydrology, with definitions: U.S. Geological Survey Water-Supply Paper 494, 71 p.

National Agriculture Statistics Service, 2013, County estimates: U.S. Department of Agriculture, accessed December 4, 2013, at http://www.nass.usda.gov/Statistics by_State/Oklahoma/Publications/County_Estimates/index. asp.

National Oceanic and Atmospheric Administration, 2012, Precipitation data from Oklahoma Climate Division 7 Southwest: National Climatic Data Center, accessed June 19, 2012, at http://www7.ncdc.noaa.gov/CDO/ CDODivisionalSelect.jsp. 
Oklahoma Department of Agriculture, Food and Forestry, 2012, Oklahoma Agricultural Statistics 2012, 80 p.

Oklahoma Mesonet, 2013, Oklahoma Climatological Survey, Daily data retrieval, accessed June 18, 2013, at http://www. mesonet.org/index.php/weather/daily_data_retrieval.

Oklahoma Water Resources Board, 2013, Water well record search: accessed November 26, 2013, at http://www.owrb. ok.gov/wd/search/search.php?type=wl.

Rosenberry, D.O., and LaBaugh, J.W., 2008, Field techniques for estimating water fluxes between surface water and ground water: U.S. Geological Survey Techniques and Methods 4-D2, $128 \mathrm{p}$.

Rus, D.L., McGuire, V.L., Zurbuchen, B.R., and Zlotnik, V.A., 2001, Vertical profiles of streambed hydraulic conductivity determined using slug tests in central and western Nebraska: U.S. Geological Survey Water-Resources Investigations Report 2001-4212, 32 p.

Rutledge, A.T., 1998, Computer programs for describing the recession of ground-water discharge and for estimating mean ground-water recharge and discharge from streamflow records-Update: U.S. Geological Survey Water-Resources Investigations Report 98-4148, 43 p.

Springer, R.K., and Gelhar, L.W., 1991, Characterization of large-scale aquifer heterogeneity in glacial outwash by analysis of slug tests with oscillatory response, Cape Cod, Massachusetts: U.S. Geological Survey Water-Resources Investigations Report 91-4034, p. 36-40.

Tanaka, H.H., and Davis, L.V., 1963, Ground-water resources of the Rush Springs Sandstone in the Caddo County area, Oklahoma: Oklahoma Geological Survey Circular 61, $33 \mathrm{p}$.
Tortorelli, R.L., 2009, Water use in Oklahoma 1950-2005: U.S. Geological Survey Scientific Investigations Report 2009-5212, 49 p.

U.S. Department of Agriculture Farm Service Agency, 2013, National Agriculture Imagery Program: Aerial Photography Field Office, accessed January 30, 2013, at http:/www.fsa. usda.gov/FSA/apfoapp?area=home\&subject=prog\&topic $=$ nai.

U.S. Department of Agriculture Natural Resources Conservation Service, 2006, Watershed Boundary Dataset (WBD): Natural Resources Conservation Service, accessed January 30, 2006, at http:/www.ncgc.nrcs.usda.gov/ products/datasets/Watershed/.

U.S. Department of Agriculture Natural Resources Conservation Service, 2013, Digital soil map of U.S.: accessed January 30, 2013, at http://datagateway.nrcs.usda. gov/.

U.S. Fish and Wildlife Service, 2013, National Wetlands Inventory: Ecological Services, accessed January 31, 2013, at http://www.fws.gov/wetlands/data/.

U.S. Geological Survey, 2013, USGS water use data for Oklahoma, National Water Information System: U.S. Geological Survey, accessed January 31, 2013, at http://waterdata.usgs.gov/ok/nwis/wu.

Zlotnik, V.A., 1994, Interpretation of slug and packer tests in anisotropic aquifers: Ground Water, v. 32, no. 5, p. 761-766.

Zlotnik, V.A., and McGuire, V.L., 1998, Multi-level slug tests in highly permeable formations - 1 . Modification of the Springer-Gelhar (SG) model: Journal of Hydrology, v. 204, no. 1, p. 271-282. 
